ANDRÉ MACHADO DIAS FERREIRA

ESTUDO DOS ASPECTOS AVALIADOS EM DECISÕES DE TERCEIRIZAÇÃO DE TECNOLOGIA DA INFORMAÇÃO

São Paulo

2008 
ANDRÉ MACHADO DIAS FERREIRA

ESTUDO DOS ASPECTOS AVALIADOS EM DECISÕES DE TERCEIRIZAÇÃO DE TECNOLOGIA DA INFORMAÇÃO

Dissertação apresentada à Escola Politécnica da Universidade de São Paulo para obtenção do título de Mestre em Engenharia

São Paulo 
ANDRÉ MACHADO DIAS FERREIRA

\section{ESTUDO DOS ASPECTOS AVALIADOS EM DECISÕES DE TERCEIRIZAÇÃO DE TECNOLOGIA DA INFORMAÇÃO}

Dissertação apresentada à Escola Politécnica da Universidade de São Paulo para obtenção do título de Mestre em Engenharia

Área de concentração:

Engenharia de Produção

Orientador: Prof. Livre-Docente Fernando José Barbin Laurindo

São Paulo 
Este exemplar foi revisado e alterado em relação à versão original, sob responsabilidade única do autor e com a anuência de seu orientador.

São Paulo, de dezembro de 2008.

Assinatura do autor

Assinatura do orientador

\section{FICHA CATALOGRÁFICA}

\section{Ferreira, André Machado Dias}

Estudo dos aspectos avaliados em decisões de terceirização de tecnologia da informação / A.M.D. Ferreira. -- ed.rev. -- São Paulo, 2008.

$106 \mathrm{p}$.

Dissertação (Mestrado) - Escola Politécnica da Universidade de São Paulo. Departamento de Engenharia de Produção.

1.Tomada de decisão 2.Terceirização 3.Tecnologia da informação 4.Modelagem matemática 5.Simulação (Estatística) 6.Análise de regressão e de correlação I.Universidade de São Paulo. Escola Politécnica. Departamento de Engenharia de Produção II.t. 


\section{DEDICATÓRIA}

Dedico este trabalho a minha família, elemento central de orientação e incentivo à obtenção de novos conhecimentos 


\section{AGRADECIMENTOS}

Aos meus pais, pelo esforço que me possibilitou acesso à educação de base.

À minha esposa, pelo exemplo de dedicação acadêmica e pelo apoio e compreensão constantes durante o período de realização do programa.

Ao meu irmão, pelas demonstrações de superação que me serviram de incentivo.

Ao professor Fernando Laurindo, por acreditar no meu projeto e por me apoiar incondicionalmente tanto do lado acadêmico, quanto no profissional.

Aos amigos, que incentivaram e contribuíram para a realização do programa. 


\section{LISTA DE ILUSTRAÇÕES}

Figura 2.1 - Grid estratégico adaptado de McFarlan (1984) e Laurindo (2002)........38

Figura 2.2 - Novo grid estratégico adaptado de Nolan e McFarlan (2005). 39

Figura 2.3 - Modelo do alinhamento estratégico adaptado de Henderson e Venkatraman (1993). 45

Figura 4.1 - Modelo de pesquisa, árvore de decisão hierárquica com os aspectos de decisão e suas inter-relações. .59

Figura 4.2 - Resultado da simulação do caso 1 .66

Figura 4.3 - Resultado da simulação do caso 2. 67

Figura 4.4 - Resultado da simulação do caso 3. 68

Figura 4.5 - Percentual de respostas encontradas para a tipologia de sistemas de informação de acordo com Loof (1997). 69

Figura 4.6 - Percentual de respostas encontradas para a tipologia de componentes de acordo com Loof (1997). .70

Figura 4.7 - Percentual de respostas encontradas para a tipologia de atividades de acordo com Loof (1997). .70

Figura 4.8 - Nível de importância dos aspectos considerados na decisão de terceirização em TI (variáveis independentes BN). .73

Figura 4.9 - Modelo de pesquisa revisitado, árvore de decisão hierárquica com os aspectos de decisão, suas inter-relações e fatores externos que influenciam no nível de importância dos aspectos. .82 


\section{LISTA DE TABELAS}

Tabela 1.1 - Dissertações e teses que tratam do tema terceirização em TI listadas no site da CAPES.

Tabela 2.1 - Relacionamento entre os aspectos de decisão pesquisados na literatura.

Tabela 2.2 - Características dos quadrantes do novo grid estratégico de Nolan e McFarlan (2005).

Tabela 2.3 - Principais modelos de alinhamento estratégico e suas características adaptado de Bruhn (2004).

Tabela 3.1 - Variáveis utilizadas na análise estatística da questão de pesquisa Q3.

Tabela 3.2 - Variáveis utilizadas na análise estatística da questão de pesquisa Q4.

Tabela 4.1 - Aspectos considerados na decisão de terceirização de TI (variáveis independentes A1, A2, A3, A4, A5 e A6)

Tabela 4.2 - Nível de importância dos aspectos considerados na decisão de terceirização em TI (variáveis independentes BN). .72

Tabela 4.3 - Saída da correlação de Pearson para as variáveis independentes BN.

Tabela 4.4 - Novo relacionamento entre os aspectos de decisão após correlação do nível de importância adotado pelas empresas brasileiras a estes. .76

Tabela 4.5 - Saída do software Minitab para os testes de regressão Stepwise. 77

Tabela 4.6 - Síntese da discussão dos resultados encontrados frente a literatura pesquisada. 


\section{RESUMO}

A crescente importância do mercado de serviços terceirizados de TI no Brasil e o interesse por pesquisas nesse tema no Brasil e em nível mundial, são os principais argumentos que justificam a realização deste estudo. Este trabalho teve por objetivo entender questões que envolvem os aspectos considerados em decisões de terceirização de funções de $\mathrm{Tl}$ em empresas brasileiras, visão ainda pouco explorada na literatura. Para que o objetivo fosse atingido, foram propostas quatro questões de pesquisa respondidas utilizando-se de uma revisão bibliográfica, simulação e dois surveys. Os resultados encontrados permitiram identificar um modelo final que facilita um melhor entendimento sobre como a decisão de terceirização é tomada em empresas brasileiras. Tal modelo engloba seis aspectos de decisão usualmente considerados pelas empresas, o inter-relacionamento entre estes aspectos e mostra fatores externos que contribuem para a definição do nível de importância de cada aspecto na decisão. Como produto secundário, a discussão dos resultados encontrados frente à literatura que trata do tema terceirização em TI validou resultados já apresentados por outros autores e, gerou a necessidade de estudos futuros ao encontrar divergências. Do ponto de vista prático, o trabalho apresenta importante contribuição, pois ajudou a estruturar o processo de decisão de terceirização de funções de TI.

Palavras-chave: Decisão. Terceirização. Tecnologia da Informação (TI). Simulação. Survey. Modelo Linear. Papel da TI. Alinhamento Estratégico. Financeirização. Nível Hierárquico. 


\begin{abstract}
The growing importance of IT service market in Brazil and the interest for researches in this area in Brazil and worldwide are the main arguments that justifies the development of this study. The objective of this work was to understand the issues that involve the aspects considered on IT outsourcing decisions in Brazilian companies, theme that is not well explored in the literature. To achieve this objective, it was proposed four research questions answered by a bibliographic revision, simulation and two surveys. The founded results allowed the identification of a final model that facilitates a better understanding about how outsourcing decision making process occurs in Brazilian companies. This model considers six decisions aspects usually considered by the companies, the inter-relationship between this aspects and shows external factors that contributes to the definition of the importance level of each of these aspects in the decision making process. As secondary product, the discussion of the founded results against the literature that covers IT outsource theme, validated the results already presented by other authors and created the need of future researches by presenting some different results. From practicing stand point, this work presents an important contribution, by helping to structure the IT outsourcing decision making process.
\end{abstract}

Keywords: Decision. Outsourcing. Information Technology (IT). Simulation. Survey. Linear Model. IT Role. Strategic Alignment. Financialization. Hierarchical Level. 


\section{SUMÁRIO}

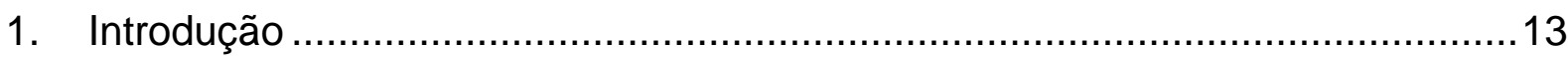

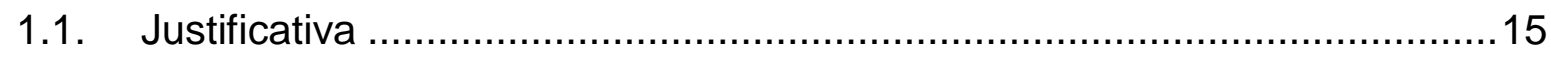

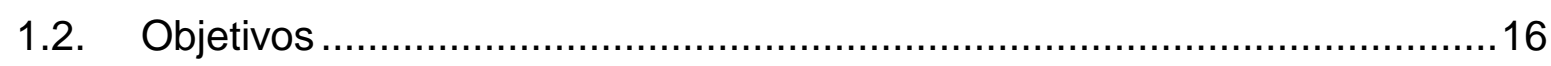

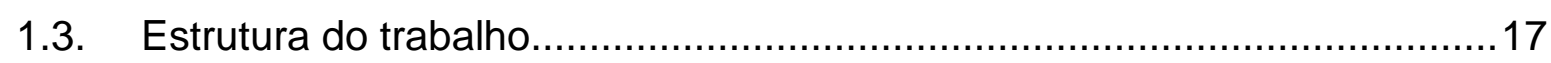

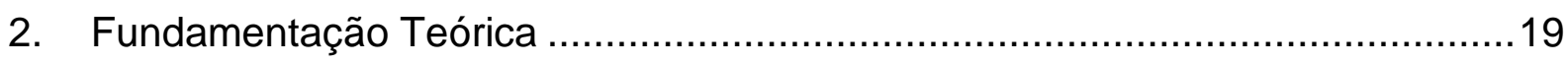

2.1. Terceirização em TI: conceito e tipologia …………………...................19

2.2. Aspectos de decisão de terceirização em TI............................................22

2.2.1. Terceirização como estratégia de TI.................................................23

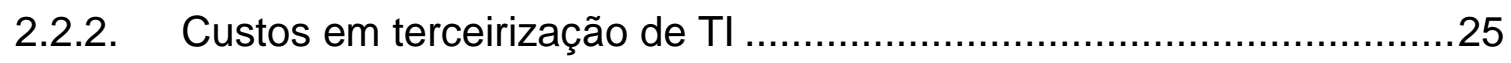

2.2.3. Contratos e gestão de fornecedores de serviços de TI terceirizados ..26

2.2.4. Riscos de operações de TI terceirizadas ..........................................27

2.2.5. Casos de serviços de TI terceirizados (benchmarking) ......................27

2.2.6. Perfil dos profissionais de TI em serviços terceirizados.......................28

2.2.7. Inter-relação entre os aspectos de decisão .......................................29

2.3. Decisões relacionadas a TI dentro das organizações..................................31

2.4. Influenciadores do nível de importância dos aspectos de decisão de

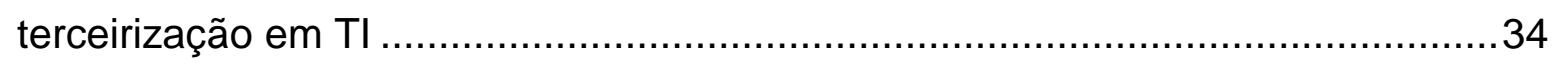

2.4.1. Financeirização, geração de valor para o acionista e o nível hierárquico

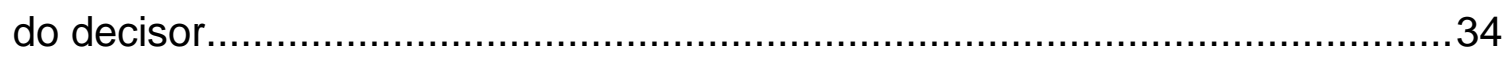

2.4.2. O papel da $\mathrm{TI}$ dentro das organizações e seu alinhamento com o negócio 38

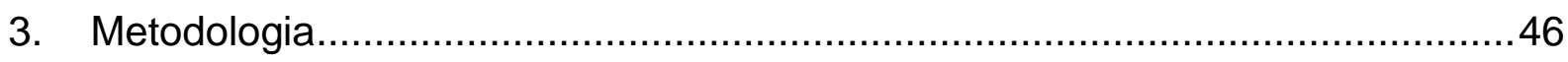

3.1. Método usado na questão de pesquisa Q1 ….........................................46 
3.2. Método usado na questão de pesquisa Q2 ..........................................48

3.3. Método usado na questão de pesquisa Q3..........................................51

3.4. Método usado na questão de pesquisa Q4 ….........................................54

4. Apresentação e discussão dos dados obtidos ..................................................59

4.1. Modelo inicial de pesquisa simulado no ANP ........................................61

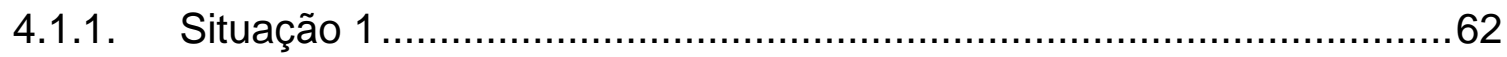

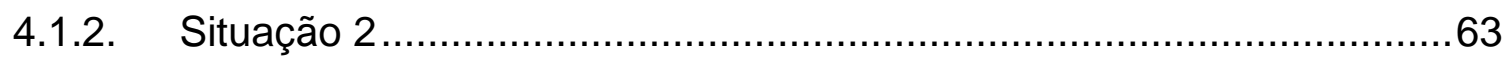

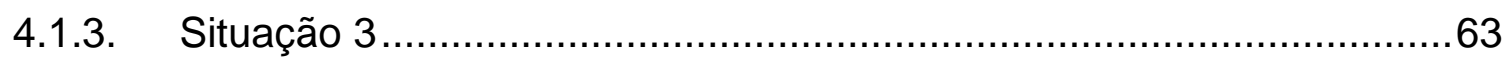

4.1.4. Resultado e discussão das simulações ............................................64

4.2. Importância dos aspectos de decisão e a real inter-relação entre eles no contexto das empresas pesquisadas..........................................................69

4.3. Fatores que influenciam o nível de importância dos aspectos de decisão em

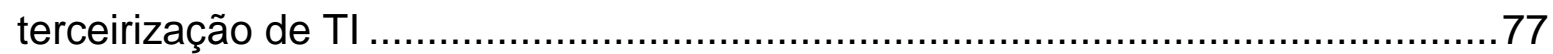

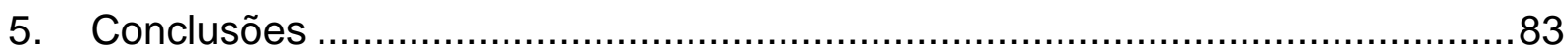

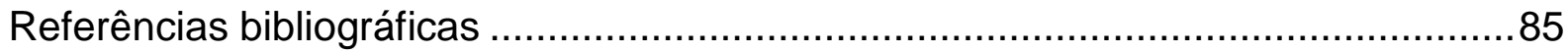

ANEXO A - Roteiro usado para responder à Questão de pesquisa Q2 …...............96

ANEXO B - Formulário usado para responder à Questão de pesquisa Q3 ..............99

ANEXO C - Formulário usado para responder à Questão de pesquisa Q4 ............103 


\section{INTRODUÇÃO}

A terceirização de atividades de Tecnologia da Informação (TI) vem sendo utilizada pelas empresas e pesquisada pela academia faz 50 anos (VASSILIADIS et al, 2006). Do ponto de vista de pesquisas científicas, em nível mundial, que buscam melhor compreensão do fenômeno da terceirização da TI, percebe-se grande esforço na direção do entendimento do que leva as empresas a terceirizarem suas operações de $\mathrm{Tl}$ e quais os aspectos envolvidos nessa decisão. As pesquisas recentes sobre o tema buscam avaliar o relacionamento em uma situação de terceirização para se maximizar o benefício (LAVINA; ROSS, 2003; TAYLOR, 2007) e avaliação de decisões relativas à reinternalização das funções de TI ou à mudança de fornecedores dos serviços de TI já terceirizados (WHITTEN; LEIDNER, 2006).

No que diz respeito às pesquisas desenvolvidas no Brasil, pode se verificar, avaliando as dissertações e teses publicadas no site da CAPES, que há interesse por este tipo de pesquisa na academia brasileira desde 1995, observando-se um crescente desenvolvimento de pesquisas nos anos de 2005 e 2006. A maior parte destes trabalhos se concentra na questão do impacto estratégico da opção de terceirização das funções de TI e como a terceirização influencia no alinhamento entre a $\mathrm{Tl}$ e o negócio. Verifica-se também um grande interesse no estudo da terceirização no setor bancário brasileiro. Finalmente, poucos estudos focaram seus esforços no entendimento da decisão da terceirização de funções de $\mathrm{TI}$, e nenhum deles procura entender os aspectos avaliados nestas decisões. A tabela 1.1 apresenta, de forma resumida, os objetivos das dissertações e teses encontradas no site da CAPES.

Tabela 1.1 - Dissertações e teses que tratam do tema terceirização em TI listadas no site da CAPES

\begin{tabular}{|l|l|}
\hline Autor & Objetivo \\
\hline Wainstok (1995) & $\begin{array}{l}\text { Avalia do nível de downsizing dos recursos de TI, o nível de } \\
\text { terceirização da área de sistemas e o nível de alinhamento } \\
\text { estratégico dos projetos de TI }\end{array}$ \\
\hline
\end{tabular}

\section{continua}




\section{conclusão}

\begin{tabular}{|c|c|}
\hline Moura (1996) & $\begin{array}{l}\text { Investiga a prática de terceirização de serviços de tecnologia de } \\
\text { informação em bancos comerciais privados }\end{array}$ \\
\hline Bernstorff (2000) & $\begin{array}{l}\text { Investiga a relação entre a forma de controle organizacional } \\
\text { sob a perspectiva do poder e da influência da eficácia dos } \\
\text { processos de terceirização da TI nos bancos instalados no } \\
\text { Brasil }\end{array}$ \\
\hline Prado (2000) & $\begin{array}{l}\text { Avaliação dos fatores que motivam a adoção da terceirização } \\
\text { da TI em empresas do setor industrial de São Paulo }\end{array}$ \\
\hline Santos (2000) & $\begin{array}{l}\text { Faz a análise do processo de terceirização e sugere mudanças } \\
\text { efetivas que poderão contribuir para melhorar os resultados } \\
\text { advindos desse processo }\end{array}$ \\
\hline Fiscina (2003) & $\begin{array}{l}\text { Analisou as falhas dos modelos tradicionais de decisão sobre } \\
\text { comprar ou fazer atividades da cadeia de valor, tomando por } \\
\text { base o relacionamento contratual na transação }\end{array}$ \\
\hline Lira (2003) & Investiga as estratégias de terceirização de TI \\
\hline Faria (2000) & $\begin{array}{l}\text { Analisa e avalia a forma como as empresas vêm gerenciando } \\
\text { seus recursos computacionais por meio da terceirização }\end{array}$ \\
\hline Ferreira (2005) & $\begin{array}{l}\text { Realiza uma investigação sobre a terceirização dos serviços de } \\
\text { TI em todos os seus aspectos (motivação, serviços } \\
\text { efetivamente terceirizados, vantagens, desvantagens e } \\
\text { possíveis obstáculos, a visão do alinhamento estratégico da TI, } \\
\text { os processos de gestão de contratos e formas de controle e, } \\
\text { por fim, tendências futuras) }\end{array}$ \\
\hline Prado (2005) & $\begin{array}{l}\text { Analisa a terceirização da TI através dos serviços terceirizados } \\
\text { e de seus arranjos contratuais }\end{array}$ \\
\hline Oliveira (2005) & $\begin{array}{l}\text { Analisa as estratégias de terceirização dos serviços da TI em } \\
\text { instituições bancárias do mercado brasileiro }\end{array}$ \\
\hline Cunha (2006) & $\begin{array}{l}\text { Descreve os desafios percebidos pelos terceirizados na } \\
\text { prestação de serviços em TI }\end{array}$ \\
\hline Gonçalvez (2006) & $\begin{array}{l}\text { Verifica a influência que a estratégia de terceirização de } \\
\text { sistemas de informação tem sobre o alinhamento entre } \\
\text { estratégia de negócios e de TI }\end{array}$ \\
\hline Muniz (2006) & $\begin{array}{l}\text { Analisa, sob a lógica dos custos de transação, como } \\
\text { mecanismos de governança são empregados nos arranjos de } \\
\text { serviços de TI, face aos riscos contratuais existentes }\end{array}$ \\
\hline Junior (2006) & $\begin{array}{l}\text { Desenvolve uma ferramenta de apoio à decisão na escolha de } \\
\text { fornecedores de serviços de } \mathrm{TI} \text {, baseado na lógica } \\
\text { paraconsistente anotada }\end{array}$ \\
\hline
\end{tabular}

Nas empresas, este movimento de terceirização é crescente em todos os setores, ganhando mais destaque perante a mídia quando se refere a TI. No Brasil, o número de postos de trabalho terceirizados cresceu $127 \%$ em 10 anos (PORTAL EXAME, 2006). Diversas empresas prestadoras de serviços de Tecnologia da Informação (TI) 
instalaram, nos últimos anos, suas operações no Brasil em busca desse crescente mercado usuário de serviços terceirizados de TI (PORTAL EXAME, 2005). A estratégia adotada por estas empresas faz transparecer que essas operações foram montadas apenas para atender ao mercado brasileiro, uma vez que os profissionais do Brasil não possuem nível de qualificação adequado, nem fluência em outras línguas para atender a outros mercados (PORTAL EXAME, 2005b).

A seção a seguir detalha as justificativas para a realização do estudo proposto com base nas informações apresentadas até este ponto.

\subsection{Justificativa}

A crescente importância do mercado de serviços terceirizados de $\mathrm{TI}$ no Brasil e o interesse por pesquisas nesse tema no Brasil e em nível mundial, são os principais argumentos que justificam a realização deste estudo. Entretanto, dentro dessa temática, diversas questões já se encontram devidamente exploradas, como, por exemplo, o impacto estratégico da terceirização e a sua influência no alinhamento entre a TI e o negócio. Uma questão pouco explorada e que merece atenção, principalmente no contexto da re-internalização e na mudança de fornecedor de serviços de TI terceirizados, diz respeito aos aspectos avaliados na decisão de terceirização de funções de TI.

Desta maneira, estudos que se proponham a avaliar quais os aspectos considerados pelas empresas nas decisões de terceirização de funções de TI, qual o nível de importância desses aspectos e quais fatores podem influenciar no nível de importância desses aspectos, podem contribuir para o melhor entendimento acerca desse fenômeno, direcionando as empresas usuárias de serviços terceirizados de $\mathrm{TI}$ em uma decisão mais coerente face à quantidade de opções que estão se formando no mercado. Por outro lado, tal conhecimento pode contribuir para que as empresas fornecedoras desenvolvam estratégias mais consistentes, atendendo assim às 
necessidades específicas dos seus clientes, caso estes atores possuam conhecimento sobre o processo decisório utilizado pelo mercado brasileiro de serviços de TI terceirizados.

\subsection{Objetivos}

Diante do exposto, este trabalho tem por objetivo buscar um melhor entendimento sobre as questões que envolvem os aspectos abordados nas decisões de terceirização de funções de TI. Especificamente, essa pesquisa tem por objetivo mapear quais os principais aspectos considerados pelas empresas quando estas avaliam a decisão de terceirização de funções de TI e a inter-relação entre estes aspectos, qual o nível de importância que cada um destes aspectos possui e quais fatores podem influenciar o nível de importância desses aspectos nas empresas. A definição destes pontos permitirá, também, a construção de um modelo de apoio a decisões desta natureza, podendo o mesmo ser simulado em uma ferramenta matemática. Para que tais objetivos possam ser alcançados, o trabalho se propõe a responder as seguintes questões de pesquisa:

Q1 - É possível verificar na literatura que trata do tema terceirização em TI quais os aspectos considerados em decisões de terceirização de funções de TI? Em caso positivo, quais são estes aspectos?

Q2 - Com base nos aspectos de decisão e seus inter-relacionamentos levantados na literatura, é possível a construção e a simulação de um modelo para a determinação do nível de importância de cada aspecto?

Q3 - Considerando os aspectos de decisão levantados na literatura, qual o nível de importância de cada um deles para as empresas brasileiras que passaram pelo processo de terceirização de suas funções de TI e qual a inter-relação entre estes fatores? 
Q4 - Quais são os fatores externos que podem influenciar no nível de importância dos aspectos de decisão de terceirização de funções de TI e que tipo de influência eles trazem?

Neste trabalho, cada pergunta apresentada será respondida por um método de pesquisa distinto. A forma como cada método responderá à sua respectiva pergunta será detalhada na seção metodologia.

O item a seguir detalha cada uma das partes desse trabalho, buscando explicar como cada parte descrita se encaixa dentro do contexto pesquisado.

\subsection{Estrutura do trabalho}

Esse documento está estruturado da seguinte maneira. O capítulo 2 apresenta a fundamentação teórica usada no trabalho. Na seção 2.1 são apresentados os conceitos e tipologias relacionadas à terceirização de $\mathrm{TI}$ de forma que o leitor possa se ambientar com o tema e se situar em relação ao tema decisão de terceirização em TI. Dando continuidade, na seção 2.2 são apresentados os aspectos avaliados em decisões de terceirização de TI. Essa seção apresenta seis aspectos de decisão organizados dentro de uma tipologia montada pela análise da revisão da literatura que trata desse tema. Além disso, essa seção apresenta a forma como cada um desses aspectos se inter-relaciona em decisões de terceirização de funções de TI. As informações apresentadas nas seções 2.1 e 2.2 formam o alicerce que embasa a pesquisa relacionada às questões de pesquisa Q1, Q2 e Q3.

A seção 2.3 descreve o processo que as empresas se utilizam para tomar decisões relativas a $\mathrm{TI}$, assim como as ferramentas matemáticas utilizadas pelas empresas como auxílio à decisão, encontrado na literatura. Além disso, essa seção apresenta alguns estudos que se propuseram a pesquisar o uso de tais ferramentas em decisões na área da gestão da Tl. As informações apresentadas nessa seção servem de base para a pesquisa voltada para às questões de pesquisa Q2 e Q3. Já 
a seção 2.4 se propõe a descrever que tipos de fatores podem influenciar no nível de importância dos aspectos avaliados em decisão de terceirização de TI. Na seção 2.4 são apresentadas também que tipos de influências tais fatores criam para a gestão das empresas. Assume-se que são estas influencias na gestão das empresas que podem alterar o nível de importância associado a cada aspecto de decisão. As informações apresentadas nessa seção são base para a pesquisa voltada à questão Q4.

O capítulo 3 apresenta as metodologias utilizadas para responder a cada uma das quatro questões de pesquisa. O capítulo 3 apresenta também as variáveis independentes e dependentes usadas nas análises estatísticas referentes às questões de pesquisa Q3 e Q4.

No capítulo 4 são apresentados e discutidos os resultados encontrados em cada uma das pesquisas realizadas para responder às questões de pesquisa do trabalho. Os resultados encontrados são apresentados e discutidos de acordo com a questão de pesquisa a qual eles fazem parte.

Finalmente, o capítulo 5 apresenta as conclusões do trabalho e as sugestões de pesquisa que poderão dar continuidade ao desenvolvimento do conhecimento acerca das questões tratadas nesse texto. 


\section{FUNDAMENTAÇÃO TEÓRICA}

\subsection{Terceirização em Tl: conceito e tipologia}

Um dos serviços de suporte mais interessantes a se tornar parte da "revolução da terceirização" é a TI. A questão da terceirização da TI é também controversa, pois muitos argumentam que a TI não é um serviço de suporte e não deveria ser terceirizada por ser crítica para a posição competitiva de muitas organizações (LONSDALE; COX, 2000).

Lacity e Hirschheim (1993) questionam se a TI se tornou rapidamente um serviço commodity a ponto de ser mais bem gerenciado por grandes empresas. A pergunta vem da constatação de que alguns profissionais, acadêmicos e consultores aconselham executivos a terceirizar seus serviços de TI, mesmo sabendo que essa função pode ser chave para a competitividade das empresas, conceito adotado por Carr (2003).

No que diz respeito a tipologia, alguns autores classificaram a terceirização das funções da TI de acordo com determinados critérios. Para Lacity; Willcocks e Feeny (1995) a terceirização da TI pode ser classificada em três categorias: terceirização total; terceirização seletiva e; fornecimento interno.

- A terceirização total ocorre quando a área de TI terceiriza todas as suas atividades, ou aquelas que representam pelo menos $80 \%$ do orçamento.

- O fornecimento interno ocorre quando pelo menos $80 \%$ do orçamento da área de Tl é gasto com atividades internas da área de TI.

- A terceirização seletiva é caracterizada em empresas que usam cerca de $40 \%$ do seu orçamento para compra de serviços de TI no mercado. 
Cada um dos modelos em questão possui vantagens e desvantagens. Por exemplo, no primeiro modelo, dado que as empresas precisam fechar contratos de longo prazo e de volume significativo, é possível obter reduções elevadas de custo. Tal característica faz com que o modelo da terceirização total seja inflexível. Por outro lado, a terceirização seletiva é bastante flexível no que diz respeito a mudanças de fornecedores e atualizações tecnológicas, entretanto, tal flexibilidade gera ganhos de custo menores e aumento no esforço gerencial do fornecedor.

Outra forma de classificar a terceirização em TI foi proposta por Loof (1997). Para este autor a TI pode ser terceirizada de acordo com o sistema de informação, componentes e atividades.

- Os sistemas de informações podem ser classificados em primários, àqueles que executam processos ligados as atividades fim das empresas; de suporte primário, àqueles que suportam os processos ligados as atividades fim das empresas e; de suporte secundário, àqueles que suportam os processos ligados as atividades meio das empresas.

- Os componentes podem ser classificados em hardware, software, pessoas, procedimentos e dados.

- As atividades podem ser classificadas em planejamento, onde se define o direcionamento estratégico da área de $\mathrm{Tl}$; desenvolvimento, onde se realiza o desenho e construção dos sistemas de informação; implementação, onde se planeja e executa os projetos responsáveis por colocar os sistemas de informação em produção; manutenção, onde se realiza a manutenção e correção de problemas dos sistemas de informação e; operação, onde se executa as atividades necessárias para que os sistemas de informação funcionem corretamente.

Possivelmente as classificações apresentadas acima estão relacionadas com os desejos das empresas que terceirizam seus serviços de TI. De acordo com DiRomualdo e Gurbaxani (1998), existem três tipos de intenções relacionadas a decisão da terceirização da TI: melhoria dos sistemas de informação; impacto no negócio e exploração comercial. 
- Melhoria dos sistemas de informação: Os objetivos incluem, tipicamente, redução de custos, melhoria na qualidade do serviço e aquisição de novos perfis de tecnologia e competências de gestão;

- Impacto no negócio: O objetivo principal é o uso da TI para melhorar significativamente aspectos críticos para o desempenho do negócio. Para isso, é necessário um perfeito entendimento entre ligação da $\mathrm{TI}$ e do negócio, assim como a habilidade de implantação de novos sistemas e de mudanças de processos simultaneamente;

- Exploração comercial: É baseado na melhoria do retorno sobre o investimento em Tl gerando receitas e lucros. Isso pode ser feito através do licenciamento de sistemas e tecnologias desenvolvidas internamente, ou através da venda de produtos e serviços para outras empresas.

Existem também outros fatores que levam as empresas a terceirizarem suas funções de $\mathrm{Tl}$ e que devem ser considerados em uma eventual decisão a este respeito, são elas: formação de alianças estratégicas (ex: obtenção de conhecimentos fora da organização); constante mudança no ambiente de Tl; preocupação da gerência quanto ao custo e a qualidade dos serviços; queda de desempenho dos serviços de $\mathrm{Tl}$; pressão dos fornecedores de tecnologia; simplificação da agenda da gerência das empresas; fatores financeiros (ex: diminuição do ativo e aumento das despesas para redução de imposto); eliminação de um componente algumas vezes indesejado e; outros fatores (McFARLAN; NOLAN, 1995).

Os autores acima apresentam suas visões em relação a tipologia para terceirização de funções de $\mathrm{Tl}$, assim como que tipo de fatores devem ser considerados quando da tomada de decisão desta natureza. Na seção a seguir, revisa-se a literatura em busca de um entendimento mais amplo sobre os aspectos que devem ser considerados pelas empresas durante o processo de tomada de decisão de terceirização de funções de TI. 


\subsection{Aspectos de decisão de terceirização em TI}

A literatura que trata da terceirização em TI, cita seis aspectos como fatores importantes em decisões de terceirização de TI, são eles:

- Terceirização como estratégia de TI (LACITY; HIRSCHHEIM, 1993; QUINN; HILMER, 1994; LACITY; WILLCOCKS; FEENY, 1995; McFARLAN; NOLAN, 1995; DiROMUALDO; GURBAXANI, 1998; LONSDALE; COX, 2000).

- Custos em terceirização de TI (LACITY; HIRSCHHEIM, 1993; QUINN; HILMER, 1994; LACITY; WILLCOCKS; FEENY, 1995; AUBERT; RIVARD; PATRY, 1996; KIPPENBERGER, 1997; DiROMUALDO; GURBAXANI, 1998; LONSDALE; COX, 2000; BARTHELEMY, 2001; AUBERT; RIVARD; PATRY, 2004).

- Contratos e gestão de fornecedores de serviços de TI (LACITY; HIRSCHHEIM, 1993; QUINN; HILMER, 1994; LACITY; WILLCOCKS; FEENY, 1995; McFARLAN; NOLAN, 1995; DiROMUALDO; GURBAXANI, 1998; LONSDALE; COX, 2000).

- Riscos de operações de TI terceirizadas (LACITY; HIRSCHHEIM, 1993; QUINN e HILMER, 1994; LACITY; WILLCOCKS; FEENY, 1995; EARL, 1996; TAFTI, 2005).

- Casos de serviços de TI terceirizados (benchmarking) (HUBER, 1993; LACITY; HIRSCHHEIM, 1993; ARNETT; JONES, 1994; QUINN; HILMER, 1994; CROSS, 1995; LACITY; WILLCOCKS; FEENY, 1995; HURLEY; SCHAUMANN, 1997; DiROMUALDO; GURBAXANI, 1998; LONSDALE; COX, 2000).

- Perfil dos profissionais de TI em serviços terceirizados (QUINN; HILMER, 1994; LACITY; WILLCOCKS; FEENY, 1995; VENKATRAMAN, 1997; BULLEN et al, 2007). 
$\mathrm{Na}$ literatura de terceirização de $\mathrm{TI}$ em questão, frequentemente se menciona conceitos relacionados a teoria de redes, principalmente no campo econômico (LACITY; HIRSCHHEIM, 1993; QUINN; HILMER, 1994; LACITY; WILLCOCKS; FEENY, 1995; AUBERT; RIVARD; PATRY, 1996, entre outros). Portanto, estes seis fatores podem ser detalhados sob a ótica da teoria de terceirização, quando considerada mais amplamente, e da teoria redes de empresas, quando se deseja obter um melhor entendimento sobre eles. As seções abaixo descrevem cada um destes aspectos nas duas visões.

\subsubsection{Terceirização como estratégia de $\mathrm{TI}$}

Lonsdale e Cox (2000) afirmam que a consideração de dimensões como: conglomeração; integração horizontal; integração vertical e integração interna das atividades de suporte se fazem importantes no processo de terceirização. Tais dimensões podem trazer economias de escala, aumento de poder sobre o mercado, aumento na faixa de produtos e controle sobre materiais e canais de distribuição.

Em complemento, Quinn e Hilmer (1994) afirmam que a combinação da concentração de uma empresa nos suas competências principais e a terceirização estratégica das outras atividades, quando bem feita, pode trazer resultados significativos em quatro aspectos: maximização do retorno sobre os recursos internos; o desenvolvimento de barreiras contra fornecedores; utilização de investimentos, inovação e capacidades profissionais dos fornecedores aplicados a rápidas mudanças de mercado e de cenários tecnológicos, diminuindo riscos, ciclo de vida dos produtos, investimentos e criando atendimento imediato às necessidades dos clientes. Estes autores também apresentam características que delineiam o conceito de competências principais e de terceirização estratégica. Para estes autores, competências principais se caracterizam por atividades que realmente criam, ou podem criar valor único nos produtos desenvolvidos pela organização. Já a 
terceirização estratégica deve estar embasada no avanço para a competitividade, na análise dos custos transacionais, na vulnerabilidade e no grau de controle.

No quesito estratégico, a terceirização empresta os mesmos benefícios incorridos com a formação de alianças ou redes de empresas. Neste sentido, pode-se dizer que um dos maiores ganhos está relacionado a obtenção de competências no mercado, competências estas que as empresas contratantes não possuem. As competências em questão podem ser divididas em acesso a mercado ou acesso ao conhecimento necessário para a produção de um determinado bem ou serviço (LAURINDO; DIAS FERREIRA, 2006). Outra vantagem estratégica advinda da terceirização, que também é tratada na literatura de redes de empresas, diz respeito ao ganho de eficiência operacional (ex: redução de custo, previsibilidade da demanda, etc.) (BRITO, 2002).

Dado o caráter estratégico destes arranjos, seja por redes de empresas ou terceirização, nota-se que a obtenção da competência buscada envolve a dependência dos recursos necessários para que essa simbiose possa ocorrer (GRANDORI; SODA, 1995). Em decorrência dessa dependência, não é incomum que uma das partes se aproveite de outra durante o tempo do relacionamento. Khanna et al (1998) destacam que a perda destes recursos ou competências está relacionada à característica da rede (competitiva ou cooperativa) e ao comportamento do parceiro em relação a essas características, dado o potencial de lucratividade obtido com a aliança, e o tempo necessário para o aprendizado advindo do compartilhamento dos recursos.

Em suma, nota-se a questão da utilização da terceirização da Tl como ferramenta estratégica, desde que observadas as competências essenciais e a retenção dos recursos que geram essas competências essenciais (LACITY; WILLCOCKS; FEENY, 1995; McFARLAN; NOLAN, 1995 e; DiROMUALDO; GURBAXANI, 1998). Conforme apresentado por Hamel e Prahalad (1990), competências e recursos essenciais possuem uma relação intrínseca forte. 


\subsubsection{Custos em terceirização de $\mathrm{TI}$}

Os chamados custos de transação, relacionados ao esforço necessário para a administração e controle dos contratos de terceirização, são amplamente abordados na literatura como fatores importantes dentro do processo de decisão de terceirização (LACITY; HIRSCHHEIM, 1993; QUINN; HILMER, 1994; DiROMUALDO; GURBAXANI, 1998; LONSDALE; COX, 2000). A teoria dos custos de transação elaborada por Willianson (1979) considera aspectos (ex: oportunismo, dimensão de transações, especificidade do ativo, freqüência, incerteza, etc.) que afetam direta, ou indiretamente, os custos necessários para a manutenção de um relacionamento entre duas partes (FARINA; AZEVEDO; SAES, 1997). Desta forma, podem-se verificar custos "escondidos" inseridos em contratos sem o devido cuidado de elaboração. Da mesma maneira, os custos de mudança de fornecedor e de tecnologia são também abordados dentro deste processo decisório (LACITY; WILLCOCKS; FEENY, 1995; KIPPENBERGER, 1997; BARTHELEMY, 2001).

O uso de um framework de custos transacionais para examinar o comportamento da terceirização serve como ferramenta de apoio no entendimento do fenômeno da terceirização (AUBERT; RIVARD; PATRY, 1996, 2004). Ao abordar os aspectos de custos em decisão de terceirização ou em operações terceirizadas, autores como Aubert; Rivard e Patry $(1996,2004)$ destacam a relação destes aspectos com outros fatores. Por exemplo, estes autores destacam que os custos de transação envolvidos na administração dos contratos de terceirização estão diretamente ligados com o delineamento do contrato estabelecido com o fornecedor da operação ou até mesmo com a forma com que a empresa cliente decide por administrar e operar a função terceirizada. 


\subsubsection{Contratos e gestão de fornecedores de serviços de TI terceirizados}

Outro aspecto importante destacado na literatura diz respeito a contratos e gestão de fornecedores. A verificação de como os contratos podem influenciar nas decisões de terceirização, assim como na administração e controle do serviço depois de implementado são importantes para a análise do processo decisório.

Fatores peculiares a TI tornam ainda mais complexa a elaboração de contratos e sua gestão junto a fornecedores, influenciando no resultado do processo. (LACITY; HIRSCHHEIM, 1993; QUINN; HILMER, 1994; LACITY; WILLCOCKS; FEENY, 1995; MCFARLAN; NOLAN, 1995; DiROMUALDO; GURBAXANI, 1998; LONSDALE; COX, 2000). Do ponto de vista da teoria de redes de empresas, percebe-se, de uma maneira mais simples, a utilização da teoria dos custos de transação para a gestão dos relacionamentos (FARINA; AZEVEDO; SAES, 1997).

De uma maneira mais ampla, o termo governança vem ganhando força e aplicabilidade. Destaca-se que governaça neste trabalho está relacionado ao conceito de governança em redes de empresa e não de governança em TI. Autores como Humphrey e Schmitz (2000) discutem essa questão, usando, inclusive, os tipos de relacionamento apresentados na teoria dos custos de transação de Willianson (1979). De qualquer modo, parece ser relevante a questão da confiança no estabelecimento e manutenção das relações entre empresas (HUMPHREY; SCHMITZ, 1998). Dias Ferreira; Laurindo e Shimizu (2006) apresentam casos onde a o aumento de confiança entre as partes influenciou diretamente na diminuição da importância dos contratos na decisão de terceirização. 


\subsubsection{Riscos de operações de $\mathrm{Tl}$ terceirizadas}

A decisão pela terceirização de uma função de TI dentro de uma organização normalmente leva em consideração os riscos envolvidos durante a vigência do contrato. Usualmente estes fatores de risco influenciam diretamente nos custos da terceirização, diminuindo os resultados esperados. Destes fatores, riscos oriundos de contratos mal elaborados, de perda de conhecimento, de baixa motivação da equipe, entre outros, podem ser encontrados na literatura (LACITY; HIRSCHHEIM, 1993; QUINN; HILMER, 1994; LACITY; WILLCOCKS; FEENY, 1995; EARL, 1996; TAFTI, 2005). Autores como Tafti (2005) relacionam os riscos do processo de terceirização com diversos aspectos discutidos nessa seção, entre eles, os aspectos relacionados a contratos, os aspectos relacionados aos custos e, em última instância, aos aspectos estratégicos da terceirização. Na literatura que trata de redes de empresas, percebe-se que os riscos mais latentes dizem respeito a posicionamentos estratégicos. Por exemplo, Khanna; Gulati e Nohria (1998) apresenta situações onde empresas assumem uma postura oportunista de modo a adquirir uma determinada competência com uma empresa parceira. Adquirida essa competência, a empresa em questão passa a atuar no mercado como competidora da antiga parceira que the havia proporcionado a competência em questão. Ainda na literatura de redes, outros autores como Grandori e Soda (1995) também discutem a influência dessa questão nos mecanismos e formas de redes de empresas.

\subsubsection{Casos de serviços de TI terceirizados (benchmarking)}

Casos citando processos de terceirização de funções de TI podem ser encontrados na literatura, como, por exemplo, o caso do Continental Bank (HUBER, 1993) e da British Petroleum's (CROSS, 1995). Tais casos são usados como benchmark para 
análise de outros cenários e decisões relacionados à terceirização de funções da TI (LACITY; HIRSCHHEIM, 1993; DiROMUALDO; GURBAXANI, 1998; LONSDALE; COX, 2000). Outras pesquisas analisando o processo de decisão em várias empresas buscam uma tendência nas opções escolhidas (ARNETT; JONES, 1994; QUINN; HILMER, 1994; LACITY; WILLCOCKS; FEENY, 1995; HURLEY; SCHAUMANN, 1997).

Casos que descrevem modelos de relacionamento entre empresas podem também ser encontrados na literatura que trata de redes de empresas. Na realidade, essa literatura é rica em tais exemplos e pode contribuir positivamente no que diz respeito a construção de relacionamentos duradouros. Usando o conceito da teoria de custos de transação (WILLIANSON, 1979), relativo à dimensão da transação e freqüência, percebe-se que os relacionamentos em redes podem ser considerados mais duradouros que os relacionamentos em contratos de terceirização. Portanto, os casos apresentados na teoria de redes de empresas fornecem informações importantes para a construção de relacionamentos que possibilitem ganhos estratégicos e inovadores (ex: SCHMITZ, 1989; ENRIGHT, 1994; AHUJA, 2000; AFUAH, 2000; PERKS; JEFFERY, 2006).

\subsubsection{Perfil dos profissionais de $\mathrm{TI}$ em serviços terceirizados}

A forma como a TI é vista pelas organizações pode influenciar mudanças nas funções internas da TI (VENKATRAMAN, 1997). Além disso, as empresas precisaram se adaptar e aprender a trabalhar em redes a partir do momento em que esse movimento se iniciou. Pode-se dizer que a preocupação com a forma de gestão destas redes se iniciou depois que Willianson (1979) verificou que a composição em redes de empresas possuía custos, alguma vezes, significativamente superiores aos custos de administração de uma organização totalmente vertical. Na realidade, encontram-se indícios dessa preocupação já na teoria da economia industrial de 
Marshall (1920) apud Igliori (2001). Desta forma, a consideração da teoria dos custos de transação (WILLIANSON, 1979), de forma mais simples, ou dos conceitos que tratam dos mecanismos e formas de redes (GRANDORI; SODA, 1995) e de governança (HUMPHREY; SCHMITZ, 2000), mais amplamente, proporciona um melhor entendimento da evolução das competências para a gestão destes relacionamentos. De acordo com Porter (2001), em uma análise ambiental da indústria, instituições de suporte podem ser úteis no auxílio ao modelo de gestão que se configura com estas mudanças.

Diante desse contexto, deve-se considerar um entendimento sobre um novo perfil de profissional de $\mathrm{Tl}$ advindo juntamente com a prática da terceirização, uma vez que esta influencia na operação das funções de TI dentro de uma empresa (QUINN; HILMER, 1994; LACITY; WILLCOCKS; FEENY, 1995). A pesquisa realizada por Bullen et al (2007) mostra a tendência de mudança no perfil do profissional de TI, devido ao movimento de terceirização das operações de TI realizado pelas empresas. Estes autores demonstram que os critérios que efetivamente decidem a contratação de novos profissionais nesta área estão agora embasados nos conhecimentos e habilidades relativas ao negócio dessas organizações, sendo latente a necessidade por profissionais qualificados em: estratégia de compra; seleção de empresas fornecedoras; contratação e questões legais; gerenciamento de fornecedores; outros.

\subsubsection{Inter-relação entre os aspectos de decisão}

Ao abordar os aspectos de custos em decisão de terceirização ou em operações terceirizadas, autores como Aubert; Rivard e Patry $(1996,2004)$ destacam a relação destes aspectos com outros fatores. Conforme citado anteriormente, estes autores destacam que os custos de transação envolvidos na administração dos contratos de terceirização estão diretamente ligados ao delineamento do contrato estabelecido 
com o fornecedor da operação ou até mesmo à forma com que a empresa cliente decide por administrar e operar a função terceirizada. Por outro lado, autores como Tafti (2005) relacionam os riscos do processo de terceirização com diversos aspectos discutidos nessa seção, entre eles, os aspectos relacionados a contratos, os aspectos relacionados aos custos e, em última instância, aos aspectos estratégicos da terceirização.

Tabela 2.1 - Relacionamento entre os aspectos de decisão pesquisados na literatura.

\begin{tabular}{|l|l|l|l|l|l|l|}
\hline \multirow{2}{*}{$\begin{array}{l}\text { Aspecto } \\
\text { influenciador }\end{array}$} & \multicolumn{6}{|l|}{ Aspectos que recebem influência } \\
\cline { 2 - 7 } & Estratégico & Custo & Risco & Contratos & Benchmarking & Perfil profissional TI \\
\hline Estratégico & & $\mathrm{X}$ & $\mathrm{X}$ & $\mathrm{X}$ & $\mathrm{X}$ & $\mathrm{X}$ \\
\hline Custo & $\mathrm{X}$ & & $\mathrm{X}$ & $\mathrm{X}$ & $\mathrm{X}$ & $\mathrm{X}$ \\
\hline Risco & $\mathrm{X}$ & $\mathrm{X}$ & & $\mathrm{X}$ & $\mathrm{X}$ & $\mathrm{X}$ \\
\hline Contratos & $\mathrm{X}$ & $\mathrm{X}$ & $\mathrm{X}$ & & & $\mathrm{X}$ \\
\hline Benchmarking & & $\mathrm{X}$ & $\mathrm{X}$ & & & \\
\hline $\begin{array}{l}\text { Perfil } \\
\text { profissional TI }\end{array}$ & $\mathrm{X}$ & $\mathrm{X}$ & $\mathrm{X}$ & $\mathrm{X}$ & & \\
\hline
\end{tabular}

Ao avaliar o inter-relacionamento entre os aspectos de decisão apresentados na literatura pesquisada, chega-se ao cenário apresentado na tabela 2.1. A tabela 2.1 representa nas colunas os aspectos causadores do efeito e nas linhas os aspectos que recebem a influência. A tabela em questão mostra que foi encontrado na literatura um relacionamento entre o aspecto custos e todos os outros aspectos. Por outro lado, a tabela também mostra que na literatura que trata de Bechmarking, encontrou-se relacionamento deste aspecto com os aspectos Custo e Risco. 


\subsection{Decisões relacionadas a TI dentro das organizações}

Segundo Laurindo (2006), os problemas relacionados a TI dentro das empresas dão origem às seguintes decisões: desenvolvimento de TI próprio ou externo (terceirização); centralização versus descentralização das atividades de Tl; seleção de tecnologias para pesquisa e desenvolvimento; escolha de plataformas de hardware e software para implementação ou substituição; escolha dos mais diversos sistemas, entre eles, comunicação, sistemas de apoio à decisão, sistemas de informação para executivos, produção e integrados; previsão de cenários do mercado e de $\mathrm{Tl}$; reengenharia envolvendo $\mathrm{Tl}$; custos versus benefícios de projetos, tecnologias e estratégias envolvendo TI; TI como fator preponderante na orientação da empresa; busca de estratégia de $\mathrm{Tl}$; desenvolvimento do planejamento de $\mathrm{Tl}$; alocação de recursos e projetos de TI e avaliação de riscos.

Para que uma decisão possa ser tomada, se faz importante considerar uma abordagem estruturada (McIVOR, 2000). De acordo com Shimizu (2006), uma possível abordagem estruturada para a tomada de decisão inclui: (1) a definição clara do problema a ser resolvido; (2) o estabelecimento de critérios e objetivos da decisão; (3) a construção de um modelo e; (4) a geração de alternativas de decisão. Para se definir um problema, se faz necessário conhecer seus tipos e classificação. Turban e Aronson (1998) apresentaram uma tabela na tentativa de classificar os problemas de decisão de acordo com o seu tipo (estruturado, semi-estruturado e não estruturado) e o nível onde o problema ocorre (operacional, tático e estratégico). Choo (1998) apresentou uma classificação considerando o nível de incerteza e imprecisão em um dos eixos e o nível de conflito e ambigüidade em outro. De acordo com as características do problema, é possível determinar qual modelo pode ser usado para auxiliar a tomada de decisão.

Observando as classificações apresentadas anteriormente, os problemas de decisão em TI podem ser classificados, por exemplo, como não estruturados em nível 
estratégico. Além disso, são problemas com múltiplos critérios quantitativos e qualitativos (LAURINDO, 2006). Um método adequado para analisar este tipo de decisão é o chamado Analytic Hierarchy Process (AHP).

O método AHP permite que um problema complexo possa ser modelado em um formato hierárquico que representa os relacionamentos entre a meta, os objetivos (critérios), os sub-objetivos e as alternativas. Laurindo (2006) apresenta um exemplo de decisão em TI em uma empresa usando o método AHP. O exemplo menciona a decisão em questão no primeiro nível, os critérios avaliados no segundo nível e as possíveis alternativas no terceiro nível. Esse método foi construído fazendo uso de outros conceitos já existentes, mas até então desconexos (ex: comparações par-apar, julgamentos redundantes, etc.). Para que esse método possa ser colocado em prática, seus princípios e axiomas precisam ser respeitados. Por exemplo, quando ocorre o inter-relacionamento entre as alternativas e os critérios, ou entre os próprios critérios, um desses axiomas deixa de ser respeitado, não sendo possível a aplicação "direta" do AHP. Nestas situações, métodos alternativos como o Analytic Network Process (ANP) podem ser utilizados (FORMAN; SELLY, 2002).

O uso de métodos como o AHP e o ANP no auxílio a decisões relacionadas a aspectos de projetos de desenvolvimento não é incomum. Meade e Presley (2002) destacam uma série de estudos que procuram entender e modelar decisões relacionadas a projetos de pesquisa e desenvolvimento (P\&D) por meio do AHP e do ANP. Neste estudo, os autores argumentam que os modelos baseados em AHP, apresentados anteriormente, falham em considerar certos aspectos, principalmente as interações entre os níveis de tomada de decisão. Buscando solucionar o problema, os autores propõem um modelo baseado em ANP e que considera estas inter-relações.

Os métodos AHP e ANP não são os únicos em estudos voltados para análise da eficiência de métodos em processos de decisão de terceirização de funções da TI. Nadkarni e Shenoy (2004) pesquisaram a aplicação de redes Bayesianas no processo de decisão de terceirização de funções de TI. Neste trabalho, os autores partiram da aplicação de mapas causais para o desenvolvimento da rede Bayesiana. A partir daí, eles puderem simular situações e determinar a influência dos diversos 
fatores no processo decisório. Segundo os autores, as redes Bayesianas montadas com o uso de mapas causais podem ser utilizadas de maneira normativa no processo decisório. Da mesma forma, Paisittanand e Olson (2006) fizeram uso da simulação de Monte Carlo para avaliar o risco financeiro associado a uma decisão de terceirizar o desenvolvimento de uma aplicação de TI no negócio de cartões de crédito. Considerando uma série de variáveis características do negócio em questão, os autores comprovam que a melhor decisão, apresentada no resultado da simulação, teria maiores chances de contribuir para os objetivos estratégicos da empresa além de possibilitar o acesso a novos clientes e de criar diferencial competitivo.

Considerando as informações apresentadas nesta seção e a inter-relação entre os aspectos de decisão apresentados na seção 2.2.7, o método de apoio a decisão de terceirização de funções de TI mais aderente para os propósitos deste estudo é o ANP. Embora as informações apresentadas até este ponto sejam suficientes para a elaboração de uma modelo de apoio a decisão de terceirização de TI com base no ANP, questiona-se se o inter-relacionamento apresentado na seção 2.2.7 é, de fato, verdadeiro no cenário em que as empresas Brasileiras se encontram. Além disso, é possível que outro fator externo possa gerar algum tipo de influência na consideração do nível de importância dos aspectos. A seção seguinte descreve fatores que podem ocasionar tais impactos. 


\subsection{Influenciadores do nível de importância dos aspectos de decisão de terceirização em TI}

Conforme mencionado na seção anterior, existem diversos fatores que podem influenciar nas decisões de TI dentro das empresas. Este trabalho procurará avaliar a influência de quatro fatores nas decisões de TI. Dois destes fatores podem ser classificados como organizacionais, a questão da financeirização e a influência do nível hierárquico do tomador de decisão. Os outros dois podem ser classificados como relativos a gestão da $\mathrm{TI}$, seu papel dentro das empresas e o nível de alinhamento estratégico com o negócio.

\subsubsection{Financeirização, geração de valor para o acionista e o nível hierárquico do decisor}

Ao se avaliar parte da literatura que trata de financeirização, pode-se dizer que este fenômeno está ligado ao impacto crescente dos conceitos de finanças sobre as operações, ou mais amplamente, sobre a gestão das empresas. Tal afirmação pode ser embasada por Fligstein (2001). Este autor destaca esta evolução nas grandes empresas dos Estados Unidos da América desde o momento em que os donos destas empresas decidiram profissionalizar a gestão destas firmas, ao contratar gerentes profissionais, passando pela influência que os bancos passam a exercer nestas empresas quando estas buscam por empréstimos para o financiamento de mudanças, até a influência do mercado no controle gerencial. Essa evolução dos conceitos de finanças sobre a gestão das empresas pode ser vista de uma maneira diferente. Por exemplo, Armstrong (2002) destaca como o desenvolvimento de uma 
ferramenta financeira que busca avaliar e alocar custos indiretos gerou mudanças na gestão das empresas com a criação de novas posições e eliminação de posições antigas. Seja de uma maneira, ou de outra, essa evolução dos conceitos de finanças na gestão das empresas gerou, em última análise, o que é conhecido como valor para o acionista (FLIGSTEIN, 2001).

A visão financeira tradicional buscava a maximização dos lucros das empresas, sendo esse seu foco principal. Entretanto, a dinâmica das empresas foi alterada a partir do momento em que estas optaram pela abertura de capital como forma de obtenção de financiamento externo. Alguns autores destacam que o aumento da competitividade nos diversos mercados, como ocorreu com o mercado de automóveis, com a entrada da indústria japonesa, fez com que as empresas buscassem outros tipos de recursos para financiar mudanças que as tornassem mais competitivas (BERGER, 2005; STURGEON, 2002; USSEM, 1996). Mas nem todas as empresas buscaram recursos com a abertura de seu capital. As que buscaram, ficaram sujeitas aos efeitos da financeirização (CROTTY, 2006). A partir deste momento, ocorreu como se as empresas passassem das mãos dos seus proprietários para as mãos dos seus acionistas (FLIGSTEIN, 2001; USSEM, 1996). Com isso, os objetivos passaram a ser outros. Ao invés de se buscar simplesmente o lucro das empresas, passa-se a buscar a geração de valor para o acionista, isto é, o aumento dos ganhos das instituições que investem ao comprar ações das empresas (BLACK et al, 1998; RAPPAPORT, 2006; USSEM, 1996).

No intuito de gerar valor para os seus acionistas as empresas buscaram a estratégia de se reestruturar por diversas maneiras. Reestruturação passou a ser a estratégia de ordem dentro destas empresas (BERGER, 2005; FROUD et al, 2006). Algumas empresas se reestruturaram ao se desfazer de uma estrutura vertical, passando a concentrar suas atividades naquelas centrais aos seus negócios (BERGER, 2005; STURGEON, 2002) enquanto outras se reestruturaram fazendo uso de fusões e aquisições (FLIGSTEIN, 2001; FROUD et al, 2006). Berger (2005) destaca que as empresas foram repensadas e modeladas como partes de um lego. Cada parte deste lego possuía uma determinada função a qual precisava ser pensada em termos de atividades centrais ao negocio. Neste sentido, a autora aborda o conceito da modularidade e como este conceito se tornou um modelo nos Estados Unidos da 
América. De uma outra forma, Sturgeon (2002) destaca que este novo modelo Americano de produção é uma associação entre a modularização e a terceirização de atividades. O principal objetivo deste novo modelo é a criação de uma resposta competitiva com o objetivo de levantar a indústria Norte Americana. Pela literatura avaliada, não fica claro se estes movimentos buscam um diferencial competitivo ou, na realidade, a geração de valor para os acionistas.

Assumindo a premissa de que reestruturação, modularização e terceirização de atividades foram algumas das estratégias das empresas na tentativa de gerar valor para os acionistas, se faz necessário entender se estes movimentos realmente geraram valor para os acionistas das empresas. Nas referências pesquisadas foram encontrados estudos que buscam avaliar apenas a relação entre os movimentos de fusões e aquisições e o conceito de valor para o acionista. Fligstein (2001) avaliou o relacionamento entre o conceito de valor para o acionista e o movimento de fusão nos anos 80. Neste estudo o autor verifica que empresas que adotam os conceitos de valor para o acionista são menos suscetíveis a fusões. Tal constatação parece ser inversa ao esperado. Froud et al (2006) procura avaliar a relação entre diversos índices e a geração de valor para o acionista. Neste estudo, os autores não encontram relacionamento destes índices com a geração de valor para os acionistas das empresas estudadas, concluindo que tal movimento trata apenas de retórica para a venda de um conceito novo, o de valor para o acionista. De qualquer maneira, os textos dão indícios de que tal conceito (valor para o acionista) é relevante nos dias de hoje.

Black et al (1998) destacam que valor para o acionista é o valor presente do fluxo de caixa futuro de um negócio, descontado da média ponderada do custo de capital menos o valor do débito. $O$ conceito segue o princípio de que uma empresa só adiciona valor para o seu acionista quando o valor da ação excede o custo de capital. Nota-se que o conceito de valor pode ter mais de um sentido. O conceito acima diz respeito ao valor para o acionista, conceito esse que é diferente de valor para o cliente. Valor para o cliente é algo que ele espera que seja entregue para ele (WOMACK; JONES, 1998), mas nem sempre gerar este tipo de valor significa gerar valor para o acionista. Empresas que geram valor para o acionista são aquelas que dão retornos superiores no longo prazo, ou seja, são aquelas em que a ação se 
valoriza com mais rapidez do que a dos rivais (RAPPAPORT, 2006). Mas como a gerência das empresas consegue gerar valor para seus acionistas? Segundo Rappaport (2006) a gestão deve superar reiteradamente as expectativas do mercado para os negócios atuais ou criar novos negócios geradores de valor. Para tanto, o autor sugere 10 passos. Destes, os que se destacam no âmbito deste estudo são: tome decisões estratégicas que maximizem o valor esperado, ainda que o resultado seja um lucro menor no curto prazo; mantenha somente ativos que maximizem o valor. Além disso, o autor dá indícios de que presidentes e altos executivos conhecem melhor as necessidades dos acionistas dos que os gerentes de nível médio, por estarem mais próximos deles. Logo, parece existir diferença significativa entre a forma como os profissionais de um alto nível hierárquico agem e a forma como profissionais de baixo nível hierárquico agem.

Tais diferenças comportamentais foram criadas por novos paradigmas organizacionais como o da descentralização do processo decisório para níveis hierárquicos inferiores, obrigando as empresas a formar líderes em praticamente todos os níveis hierárquicos na busca de mais competitividade (LOWE; KROECK; SIVASUBRAMANIAM, 1996). Oshagbemi and Gill (2004) pesquisaram diferenças de estilos gerenciais entre três níveis hierárquicos (alto gerente, médio gerente e baixo gerente) e encontram diferenças significativas no estilo de liderança transformacional entre altos gerentes e médios gerentes e entre altos gerentes e baixos gerentes, mas não entre médios gerentes e baixos gerentes. Entretanto, estes autores não encontraram diferenças significativas no estilo de liderança transacional entre todos os níveis. Para Dunham e Klafehn (1990) os gerentes transformacionais possuem senso de missão e estão preocupados com objetivos de longo prazo. De acordo com Avolio e Bass (1988) líderes em mais alta posição hierárquica tendem a desempenhar estilo de liderança transformacional, pois eles têm a possibilidade de mudar a organização em que atuam tomando decisões estratégicas periodicamente. Por outro lado, gerentes médios e gerentes envolvidos em atividades especializadas tendem a desempenhar estilo de liderança transacional. Gerentes transacionais são aqueles que estão preocupados com mudanças nas atividades cotidianas e rotineiras, mas não com transações estratégicas. Esse mesmo resultado também foi encontrado por Lowe; Kroeck e Sivasubramaniam (1996). Bass et al (1987) destaca 
a possibilidade de efeito cascata de um determinado estilo gerencial entre os diversos níveis hierárquicos. Segundo o autor tal efeito pode ocorrer quando um profissional em um nível abaixo espelha seu comportamento no estilo gerencial de profissionais de nível hierárquico acima, ou quando o profissional de um nível hierárquico superior seleciona profissionais com o mesmo perfil que o seu para trabalhar com ele.

\subsubsection{O papel da TI dentro das organizações e seu alinhamento com o negócio}

É possível que diversos assuntos relacionados com TI sofram impacto do seu papel ou da sua percepção de importância na organização, devendo ser considerada a importância estratégica da $\mathrm{TI}$ agora e/ou no futuro para a análise de algumas decisões (NEUMANN; AHITUV; ZVIRAN, 1992). Existe uma série de metodologias para a determinação do posicionamento da TI na organização. Uma delas, muito disseminada, e muito útil para atuar como meio de comunicação eficaz com a alta gerência é o grid estratégico (McFARLAN; McKENNEY; PYBURN,1983; McFARLAN, 1984). McFarlan; McKenney e Pyburn (1983) apresentaram o conceito do grid estratégico, o qual procura descrever quais os possíveis posicionamentos que a $\mathrm{TI}$ pode possuir em uma organização, em função das aplicações de TI existentes e das aplicações de TI planejadas para o futuro (figura 2.1).

\begin{tabular}{c|c|c|}
\cline { 2 - 3 } \multirow{4}{*}{$\begin{array}{c}\text { Impacto } \\
\text { pltosente }\end{array}$} & $\begin{array}{c}\text { Fábrica } \\
\text { (ex: companhias aéreas) }\end{array}$ & $\begin{array}{c}\text { Estratégico } \\
\text { (ex: bancos e seguradoras) }\end{array}$ \\
\cline { 2 - 3 } Baixo & $\begin{array}{c}\text { Suporte } \\
\text { (ex: indústria) }\end{array}$ & $\begin{array}{c}\text { Transição } \\
\text { (ex: editoras e e-commerce) }\end{array}$ \\
\cline { 2 - 3 } & Baixo & $\begin{array}{c}\text { Impacto } \\
\text { futuro }\end{array}$
\end{tabular}

Figura 2.1 - Grid estratégico adaptado de McFarlan (1984) e Laurindo (2002) 
De acordo com McFarlan; McKenney e Pyburn (1983), o quadrante "Estratégico" caracteriza-se por aquele onde as atividades de TI são críticas para as operações existentes e as aplicações de TI planejadas são igualmente críticas para o sucesso futuro. No quadrante "Transformação", as empresas no presente não são dependentes das aplicações de TI, mas as novas aplicações de TI são vitais para os objetivos da organização. As organizações situadas no quadrante "Fábrica" dependem das aplicações de TI para o seu funcionamento diário; entretanto, as novas aplicações não significarão vantagens futuras. Por fim, o quadrante "Suporte" abriga aquelas organizações que não são nem dependentes das aplicações de TI, nem as aplicações futuras trarão vantagens competitivas.

Em muitas organizações os executivos concluem que a TI está no quadrante "Fábrica" ou "Suporte", mas esquecem de que as mudanças de tecnologia e as condições competitivas podem alterar este posicionamento e a forma de como a TI será gerida (McFARLAN, 1984).

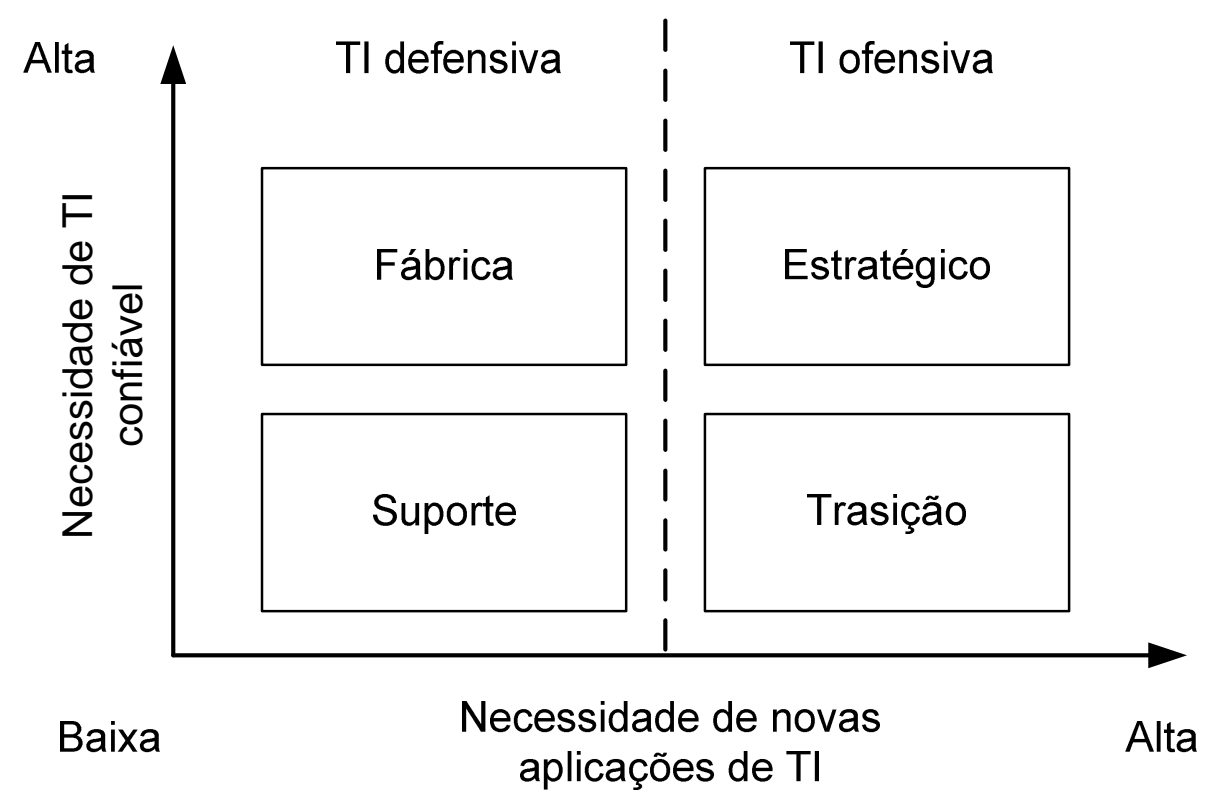

Figura 2.2 - Novo grid estratégico adaptado de Nolan e McFarlan (2005).

Nolan e McFarlan (2005) revisitaram o grid estratégico e detalharam cada um dos quadrantes com novas características complementares à idéia de papel presente e 
impacto das aplicações futuras. Conceitos como tempo de disponibilidade de aplicações e percentual de gastos do orçamento foram adicionados a alguns quadrantes. Além disso, uma nova tipologia quanto ao posicionamento defensivo ou ofensivo da TI na organização foi proposto pelos autores. O novo formato do grid estratégico é apresentado na figura 2.2 e tem as características dos quadrantes descritas na tabela 2.2.

Tabela 2.2 - Características dos quadrantes do novo grid estratégico de Nolan e McFarlan (2005).

\begin{tabular}{|c|c|}
\hline Quadrante & Características \\
\hline Suporte & $\begin{array}{l}\text { Mesmo com interrupções repetidas por mais de } 12 \text { horas, não há } \\
\text { sérias conseqüências } \\
\text { O tempo de resposta ao usuário pode subir até cinco segundos para } \\
\text { transações on-line } \\
\text { Os sistemas internos são pouco visíveis para os fornecedores e } \\
\text { clientes. Pouca necessidade de extranet } \\
\text { A empresa pode reverter seus processos para execução manual em } \\
80 \% \text { das suas transações } \\
\text { Os sistemas são apenas mantidos pela empresa }\end{array}$ \\
\hline Fábrica & $\begin{array}{l}\text { Se o sistema falhar por um minuto ou mais, há uma perda imediata } \\
\text { para o negócio } \\
\text { Se o tempo de resposta da aplicação diminuir em um segundo, há } \\
\text { sérias conseqüências para os usuários internos e externos } \\
\text { A maioria das atividades principais da empresa é on-line } \\
\text { Os sistemas são apenas mantidos pela empresa } \\
\text { Os sistemas proporcionam pequena diferenciação estratégica ou } \\
\text { redução de custo }\end{array}$ \\
\hline Transição & $\begin{array}{l}\text { Novos sistemas prometem significativas transformações nos } \\
\text { processos e serviços } \\
\text { Novos sistemas prometem significativas reduções de custo } \\
\text { Novos sistemas diminuirão significativamente a distância do } \\
\text { desempenho de custo, serviço e processo entre a empresa e seus } \\
\text { competidores } \\
\text { A TI constitui mais do que } 50 \% \text { dos gastos de capital da empresa } \\
\text { As despesas com TI somam mais do que } 15 \% \text { das despesas totais da } \\
\text { empresa }\end{array}$ \\
\hline Estratégico & $\begin{array}{l}\text { Se o sistema falhar por um minuto ou mais, há uma perda imediata } \\
\text { para o negócio } \\
\text { Se o tempo de resposta da aplicação diminuir em um segundo, há } \\
\text { sérias conseqüências para os usuários internos e externos } \\
\text { Novos sistemas prometem significativas transformações nos } \\
\text { processos e serviços } \\
\text { Novos sistemas prometem significativas reduções de custo } \\
\text { Novos sistemas diminuirão significativamente a distância do } \\
\text { desempenho de custo, serviço e processo entre a empresa e seus } \\
\text { competidores }\end{array}$ \\
\hline
\end{tabular}


Nolan (1979) apresenta seis estágios que ajudam a compreender a evolução do uso da TI em uma organização: iniciação, contágio, controle, integração, administração de dados e maturidade. A passagem de um estágio para outro implica em mudanças na forma como são escolhidas as aplicações de TI, na maneira como os recursos de TI são gerenciados, bem como na postura dos usuários. Ao passar do estágio de administração de computadores (que inclui os três estágios iniciais) para os estágios de integração e administração de dados, muda-se o posicionamento no grid estratégico. Portanto, pode-se considerar que o posicionamento da TI está relacionado, entre outros fatores, com seu nível de maturidade.

Além dos modelos de avaliação do papel da TI dentro das organizações apresentadas anteriormente, existem alguns outros destacados na literatura, como, por exemplo, a matriz de intensidade de informação de Porter e Millar (1985), que se baseia na cadeia de valor da organização e verifica o quanto de informação está contido no produto e no processo. Outro modelo de destaque é o dos fatores críticos de sucesso (FCS), de Rockart (1979), que analisa a importância dos sistemas de informação de uma organização com base nos fatores críticos para o sucesso do negócio. Este modelo foi concebido para dar origem a sistemas de informações gerenciais alinhados às necessidades dos gerentes, mas pode trazer impactos nos sistemas transacionais e também em outros aspectos gerenciais (como priorizar a atenção dos executivos).

A escada de avaliação de benefícios de Farbey; Land e Targett (1995) é um modelo que se propõe a sanar a limitações de outros modelos de caráter predominantemente analíticos, sendo voltado para a avaliação e para a ação. Enquanto os outros modelos enxergavam a evolução do uso da Tl seguir um curso determinístico (NOLAN, 1979) ou voltados às implicações estratégicas (McFARLAN, 1984), prestando-se apenas a compreensão e não a ação sobre as aplicações de TI, o modelo de Farbey; Land e Targett (1995) preocupa-se em fornecer elementos para avaliação e tomada de decisão. Este modelo apresenta a escada de benefícios, sendo a importância da $\mathrm{TI}$ crescente à medida que se sobe na escada. $\mathrm{O}$ modelo apresenta oito tipos de aplicações de $\mathrm{TI}$, cada um correspondente a um degrau da 
escada: mudanças obrigatórias ou mandatórias; automação; sistemas de valor adicionado; sistemas de informações gerenciais e sistemas de apoio à decisão; infra-estrutura; sistemas interorganizacionais; sistemas estratégicos e transformação do negócio.

Já o modelo proposto por Willcocks e Lester (1997) foi originado pela discussão da produtividade e da avaliação da TI e questiona o "paradoxo da produtividade" (LAURINDO, 2002). Para os autores deste modelo, o processo de avaliação deve conter medidas integradas que envolvam aspectos técnicos e de negócio. Deve conter informações sobre aplicações de TI a serem desenvolvidas, abandonadas e melhoradas. Deve, também, envolver todos aqueles que influenciam no processo decisório. A abordagem do ciclo de vida de Willcocks e Lester (1997) contém, entre outros pontos, o alinhamento estratégico e a priorização.

Apesar de ser estudado desde o final dos anos 80, o alinhamento estratégico da $\mathrm{TI}$ permanece sendo apontado como um dos principais problemas enfrentados pelos executivos de negócio e de tecnologia (PAPP; LUFTMAN, 1995; CHAN, 2002 apud BRUHN, 2004). Diversas pesquisas tenham comprovado o aumento de desempenho dos negócios pelo uso do alinhamento estratégico. A pesquisa realizada por Lederer e Mendelow (1986) concluiu que o planejamento da TI é reconhecidamente importante. Seus estudos reportam que empresas que alinham a estratégia de $\mathrm{TI}$ à estratégia do negócio possuem desempenho melhor que as empresas que não o fazem por uma relação média de 6 para 1. Os estudos mencionados por estes autores mostram que esta melhora é causada principalmente pela redução de custos, aumento de controle e aumento das receitas. Entretanto, a falta de habilidade das empresas em realizar valor por investimentos em TI ainda ocorre (WILLCOCKS; LESTER, 1997). Para Henderson e Venkatraman (1993), tal falta de habilidade reside, em grande parte, nas falhas de alinhamento entre as estratégias de negócio e de TI.

No que diz respeito ao alinhamento estratégico entre a $\mathrm{TI}$ e o negócio, existem diversos modelos na literatura que abordam esta temática. Na tentativa de entender melhor os principais modelos, Bruhn (2004) analisou os principais deles, suas interrelações e limitações. Segundo este autor, os modelos desenvolvidos são 
complementares entre si, explorando e enfatizando os vários fatores de sucesso na disciplina do alinhamento estratégico: o alinhamento estratégico trata do compartilhamento de vontades e comprometimento (WALTON, 1993); é um processo iterativo (BRODBECK, 2001); envolve todos os níveis da organização (ROCKART; MORTON, 1984; HENDERSON; VENKATRAMAN, 1993); aborda gestão de pessoas (REICH; BENBASAT, 1996) e; é sinônimo de uniformidade (PAPP; LUFTMAN, 1995). A tabela 2.3 apresenta, de forma resumida, a abordagem de Bruhn (2004) sobre cada um dos modelos mencionados.

Tabela 2.3 - Principais modelos de alinhamento estratégico e suas características adaptado de Bruhn (2004).

\begin{tabular}{|l|l|}
\hline Modelo & Características \\
\hline $\begin{array}{l}\text { Rockart e Morton } \\
(1984)\end{array}$ & $\begin{array}{l}\text { Foi o modelo precursor dos fundamentos sobre alinhamento } \\
\text { estratégico de negócio e TI. Baseia-se em elementos funcionais } \\
\text { (estratégia e estrutura organizacional, entre outros) e suas } \\
\text { mudanças e impactos organizacionais. }\end{array}$ \\
\hline Walton (1993) & $\begin{array}{l}\text { É fundamentado na criação de uma visão estratégica. Seus } \\
\text { objetos são o alinhamento, comprometimento e as } \\
\text { competências. Apresenta o triângulo estratégico abordando } \\
\text { estratégia de negócios, estratégia da organização e estratégia } \\
\text { da TI. }\end{array}$ \\
\hline $\begin{array}{l}\text { Henderson e } \\
\text { Venkatraman }\end{array}$ & $\begin{array}{l}\text { Modelo prático mais discutido na literatura. É baseado em } \\
\text { fatores internos relacionados à estrutura administrativa da } \\
\text { empresa e fatores externos que compreendem o mercado e as } \\
\text { decisões envolvidas para atendê-lo. }\end{array}$ \\
\hline $\begin{array}{l}\text { Papp e Luftman } \\
(1995)\end{array}$ & $\begin{array}{l}\text { Expansão do modelo de Henderson e Venkatraman (1993) } \\
\text { apresentando outras oito perspectivas, quatro que consideram } \\
\text { aspectos do domínio interno da organização e quatro } \\
\text { perspectivas de fusão. }\end{array}$ \\
\hline $\begin{array}{l}\text { Reich e Benbasat } \\
\text { (1996) }\end{array}$ & $\begin{array}{l}\text { Enfatiza o processo de criação e alinhamento estratégico pelo } \\
\text { ponto de vista social, envolvendo pessoas, tempo, processo de } \\
\text { decisão e comunicação. }\end{array}$ \\
\hline $\begin{array}{l}\text { Teo e King } \\
(1997)\end{array}$ & $\begin{array}{l}\text { Apresenta uma perspectiva evolucionária entre o alinhamento e } \\
\text { o planejamento de negócios e de TI, usando de quatro estágios } \\
\text { de evolução da integração. As contribuições para a performance } \\
\text { organizacional variam de acordo com os diferentes estágios de } \\
\text { evolução. }\end{array}$ \\
\hline
\end{tabular}




\section{continuação}

\begin{tabular}{|l|l|}
\hline Brodbeck (2001) & $\begin{array}{l}\text { Expande o entendimento para além do aspecto conceitual, } \\
\text { tratando-o como ferramenta de monitoramento e gestão das } \\
\text { estratégias e objetivos da organização ao longo do período de } \\
\text { aplicação do plano de negócios e de TI. Combina os modelos de } \\
\text { Henderson e Venkatraman (1993), Reich e Benbasat (1996) e } \\
\text { Teo e King (1997), cruzando o alinhamento entre planejamento } \\
\text { de negócios e de TI, alinhamento entre ambientes internos e } \\
\text { externos e alinhamento temporal de forma contínua e } \\
\text { permanente. }\end{array}$ \\
\hline
\end{tabular}

Dentre os modelos listados acima, o proposto por Henderson e Venkatraman (1993) apresenta bases importantes para o entendimento do alinhamento estratégico entre negócios e TI (LAURINDO, 2002). Para Henderson e Venkatraman (1993) não existe um modelo ideal para descrever e implementar o alinhamento entre a estratégia de TI e a de negócios, entretanto, existem modelos que podem auxiliar essa implementação. O modelo descrito por estes autores é baseado em quatro fatores (ou domínios): estratégia de negócios, estratégia de TI, infra-estrutura e processos organizacionais e infra-estrutura e processos de TI. Estes fatores são agrupados em dois blocos (ajuste estratégico e integração funcional) e procura-se em identificar os dois tipos de integração dentro do domínio do negócio e da TI. A figura 2.3 ilustra o modelo de alinhamento estratégico proposto por Henderson e Venkatraman (1993). O termo integração estratégica define a ligação entre a estratégia do negócio e a estratégia de $\mathrm{TI}$, refletindo os componentes externos à organização, ou seja, representa a capacidade da $\mathrm{TI}$ de suportar a estratégia do negócio, o que é importante devido ao papel de vantagem competitiva que a $\mathrm{TI}$ vem ocupando. $\mathrm{O}$ segundo termo, integração operacional, define a relação entre a infra-estrutura e processo da organização e da TI, caracterizando as vantagens operacionais trazidas pela TI como redução de custos e aumento de produtividade. 


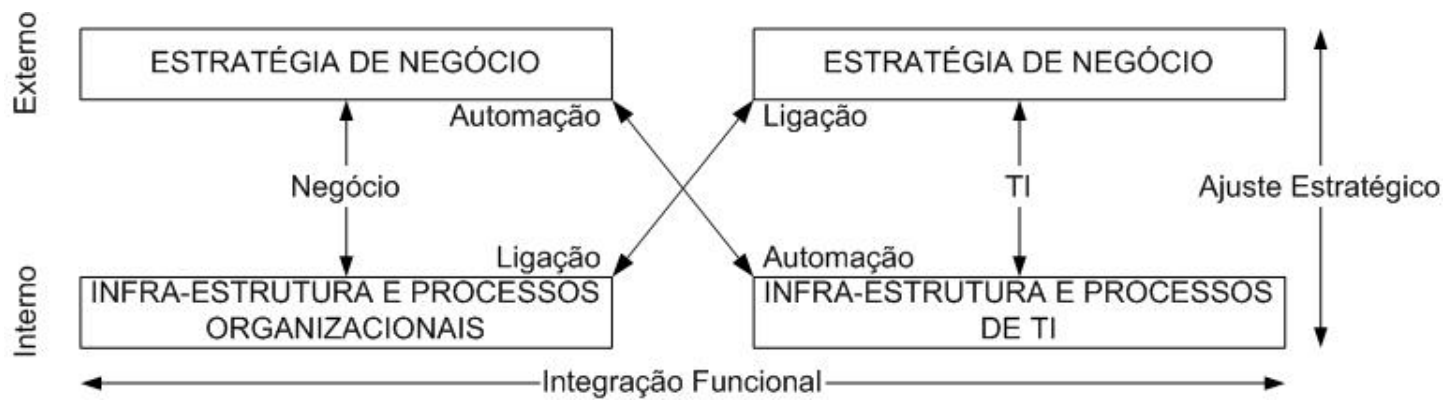

Figura 2.3 - Modelo do alinhamento estratégico adaptado de Henderson e Venkatraman (1993).

O modelo de Henderson e Venkatraman (1993) foi posteriormente trabalhado por outros autores. Luftman; Papp e Brier (1996) buscou avaliar a implementação prática do modelo de Henderson e Venkatraman (1993) assim como suas implicações. Nesta pesquisa os autores propuseram um roteiro prático para o uso do alinhamento, descrevendo as características do ponto de início do processo, o ciclo de passagem pelos quatro componentes (horário ou anti-horário) e o número de iterações necessárias para que o processo de alinhamento seja alcançado, caracterizando assim o fato de que esse processo não se dá em uma única oportunidade.

Já Luftman (2003) buscou avaliar o nível de maturidade do alinhamento entre a TI e o negócio nas empresas. Neste trabalho o autor propõe 12 componentes que compõem o alinhamento entre a TI e o negócio, assim como uma ferramenta para medir o nível deste alinhamento nas empresas. Com base na ferramenta mencionada anteriormente e em pesquisas realizadas em diversas empresas, Luftman; Papp e Brier (1996) também propuseram seis pontos que podem fortalecer o enfraquecer o alinhamento entre a TI e o negócio nas organizações, são eles: suporte a TI; $\mathrm{TI}$ envolvida no desenvolvimento da estratégia; entendimento do negócio pela TI; parceria entre a TI e o negócio; projetos de TI bem priorizados e; demonstração de liderança por parte da TI. 


\section{METODOLOGIA}

Conforme mencionado inicialmente, este trabalho tem por objetivo buscar um melhor entendimento sobre as questões que envolvem os aspectos abordados nas decisões de terceirização de funções de TI. Para tanto, foram propostas quatro questões a serem pesquisadas de modo a buscar o entendimento citado. Cada uma das questões sugeridas possui características diferentes a serem exploradas. Desta forma, propõe-se a utilização de quatro métodos de pesquisa distintos, sendo cada um deles aplicável a uma respectiva questão.

\subsection{Método usado na questão de pesquisa Q1}

No que diz respeito a questão de pesquisa Q1 (É possível verificar na literatura que trata do tema terceirização em TI quais são os aspectos considerados em decisões de terceirização de funções de TI? Em caso positivo, quais são estes aspectos?), $O$ método de pesquisa utilizado para responder a esta pergunta foi o de levantamento bibliográfico. Para o desenvolvimento da pesquisa bibliográfica, os seguintes passos foram seguidos:

- Dado o objetivo da pesquisa, em uma primeira "rodada", as seguintes palavras chave foram utilizadas na busca de artigos relevantes para o tema: information technology outsourcing.

- Artigos com as palavras chave apresentadas acima foram buscados nas seguintes bases: Proquest ABI/Inform, Science Direct, Emerald Insight e 
Harvard Business Review. Em cada busca, os resultados apresentados foram salvos para controle e uso posterior.

- Os abstracts dos artigos encontrados nos mecanismos acima foram avaliados a fim de determinar quais textos possuíam maior relevância para o tema.

- A leitura dos artigos mencionados acima possibilitou um delineamento mais preciso das questões que a pesquisa busca responder. Entretanto, outras dúvidas ainda permaneceram abertas. Para esclarecer às dúvidas remanescentes, na medida em que os artigos foram lidos, novas informações foram levantadas.

- À medida que estes artigos foram lidos, novas referências foram encontradas no tocante ao tema e a metodologias de pesquisa. Neste processo, caso se verificasse a relevância do texto para o tema, ele era coletado seguindo os passos anteriores.

- Adiantado o processo de busca e extração de conteúdo dos textos em artigos, conforme apresentado acima, buscou-se dissertações e teses desenvolvidas no Brasil sobre o tema em questão. A pesquisa foi conduzida na base de Teses da CAPES e da USP.

- O objetivo dessa busca foi o de analisar o nível de interesse pelo tema na comunidade acadêmica brasileira. Além disso, estas produções poderiam possuir informações importantes sobre novas referências e metodologia de pesquisa.

- A busca por dissertações e teses nas bases mencionadas usou como palavras chave: terceirização e tecnologia da informação.

- Livros foram utilizados apenas quando se verificou recorrência de citação em artigos e trabalhos de pós-graduação, ou quando da necessidade de utilização de conceitos clássicos, como aqueles relacionados a metodologia de pesquisa, análises estatísticas ou temas amplamente explorados.

Tendo levantado todas as informações referentes aos aspectos de decisão de terceirização de funções de TI, partiu-se para a elaboração do modelo usado como base para resposta às perguntas de pesquisa subseqüentes. $O$ modelo em questão 
foi desenvolvido pela aplicação do método proposto por Lave e March (1975). Segundo esses autores, um modelo é uma representação simplificada do mundo real. Além disso, eles podem ser criados pela especulação do processo que os produziram nos fatos observados. Normalmente, os modelos são avaliados de acordo com a sua habilidade de prever corretamente novos fatos. O método proposto por Lave e March (1975) é constituído de quatro passos, são eles:

- Observe alguns fatos.

- Olhe para os fatos como se eles fossem o resultado final de um processo desconhecido (modelo). A partir daí, especule sobre o processo que pode ter criado tais resultados.

- Deduza outros resultados (implicações, conseqüências e predições) do modelo desenvolvido.

- Pergunte a si mesmo quando estas implicações são verdade e desenvolva novos modelos se necessário.

\subsection{Método usado na questão de pesquisa Q2}

Para a questão de pesquisa Q2 (Com base nos aspectos de decisão e seus interrelacionamentos levantados na literatura, é possível a construção e a simulação de um modelo para a determinação do nível de importância de cada aspecto?) foi utilizado o método da simulação matemática. Neste caso, a modelagem com o uso do método ANP se justificava em função do inter-relacionamento entre os aspectos considerados, uma vez que o ANP considera o relacionamento entre os critérios e as alternativas (FORMAN; SELLY, 2002; MEADE; PRESLEY, 2002). Embora esse relacionamento também seja considerado por outros métodos (ex: redes Bayesianas), considerou-se o método ANP mais adequado porque todos os aspectos foram considerados em um mesmo nível. Para aplicação em redes 
Bayesianas, o modelo proposto deveria ser alterado para representar casualidade entre os aspectos levantados na revisão da literatura (NADKARNI; SHENOY, 2004). Além disso, a resposta da simulação do ANP pela ferramenta Super Decisions gera indicadores que podem servir de base para a determinação do nível de importância de cada aspecto.

Diante disso, os aspectos avaliados em decisão de terceirização de funções da $\mathrm{TI}$, e seus inter-relacionamentos, foram modelados em uma árvore de decisão hierárquica. Essa árvore de decisão hierárquica continha os aspectos relacionados à decisão, sendo ela inserida em uma ferramenta de simulação do método ANP Super Decisions. Para que o modelo pudesse representar da forma mais fiel possível o comportamento desse tipo de decisão, a influência entre os aspectos descritos na revisão de literatura foi agregada ao modelo dentro da ferramenta de simulação Super Decisions.

Feito isso, esse modelo foi simulado em três situações de terceirização de função da TI de uma única empresa. Note-se que os passos da metodologia proposta seguiram o modelo para estudos quantitativos apresentado por Mitroff et al (1974), o qual contém as fases de conceituação, modelagem, resolução do modelo e implementação. De acordo com Bertrand e Fransoo (2002), o modelo de Mitroff et al (1974) é particularmente importante para a avaliação do método aplicado em estudos quantitativos. Para Bertrand e Fransoo (2002), os estudos que fecham o ciclo do modelo de Mitroff et al (1974), via de regra, apresentam contribuições maiores à teoria, pois não se limitam a simular o modelo proposto. Ao contrário disso, o modelo é simulado e discutido junto ao "mundo real" de forma a aumentar sua validade e abrangência de aplicação. Bertrand e Fransoo (2002) enquadram estes estudos na categoria empírica e normativa. Essa categorização reforça o caráter do modelo de predição e normatização. Cabe ressaltar que a diferença da metodologia proposta para o ciclo fechado apresentado por Bertrand e Fransoo (2002) é a de que, enquanto essa metodologia usa estudo de caso para a validação empírica, Bertrand e Fransoo (2002) sugerem a aplicação de survey.

Desta forma, foram avaliadas três situações de terceirização de funções da TI realizados por esta empresa em busca das informações relevantes para esta 
pesquisa, de modo a verificar se existe diferença entre o nível de importância dos aspectos de decisão em cada situação. Dentro do tema decisão de terceirização de funções da $\mathrm{Tl}$, estudos avaliando casos de uma única empresa foram conduzidos com o objetivo de explorar questões relacionadas ao uso de métodos e ferramentas de apoio ao processo de decisão (ex: NADKARNI; SHENOY, 2004; PAISITTANAND; OLSON, 2006). Conforme mencionado, a metodologia usada para o levantamento de dados foi o de estudo de caso. Como justificativa para esta escolha, os estudos de caso possibilitam a obtenção de dados em profundidade e detalhe, pois estes são levantados durante o contato físico e psicológico com o fenômeno estudado através de entrevistas detalhadas (CARSON; COVIELLO, 1996; YIN, 2005). Além disso, para esta pesquisa em particular, a escolha do método de estudo de caso levou em consideração a necessidade de observação das práticas atuais.

O estudo de um único caso permitiria que um detalhamento maior de informações fosse obtido. Por outro lado, um estudo de caso único possui limitações quanto a sua generalização (VOSS; TSIKRIKTSIS; FROHLICH, 2002). Em função disso, optou-se pela escolha de um caso com três situações, de forma que uma quantidade razoável de informações em profundidade pudesse ser obtida, sendo também possível o aumento do nível de generalização com o cruzamento dos casos. As situações em questão foram escolhidas por amostragem (YIN, 2005), sendo esta uma amostra de conveniência. Estas situações estão vinculadas a uma única empresa. Cada uma destas situações serviu então de unidade de análise (YIN, 2005) para a coleta dos dados necessários para o estudo, representando também todos os tipos de terceirização de acordo com a tipologia apresentada por Loof (1997). O fato das três situações representarem todos os tipos de terceirização traz ao modelo maior validade nas simulações propostas. Desta forma, pode-se dizer que a amostra das unidades de análise se encontrava controlada (VOSS; TSIKRIKTSIS; FROHLICH, 2002).

O levantamento dos dados se deu por intermédio de entrevistas semi-estruturadas. Um roteiro para entrevistas foi montado com base na revisão da literatura. A partir daí foram realizadas entrevistas com as pessoas responsáveis pela execução das situações na empresa estudada. Como fonte de informação complementar, apresentações de venda dos fornecedores e documentações dos projetos foram 
analisadas com o intuito de levantar dados adicionais para a pesquisa. As informações levantadas foram usadas na simulação do modelo e em comparações posteriores.

Em complemento às informações coletadas com o uso dos mecanismos descritos acima, o modelo simulado foi apresentado às pessoas envolvidas no processo decisório abordado nos casos, para que elas pudessem pontuar a decisão seguindo o funcionamento do método ANP. Finalizada essa etapa, foi então comparada a decisão tomada pela empresa com a decisão apresentada pelo modelo proposto, de forma a verificar se a pontuação dos aspectos, levantados com o resultado da simulação ANP, conseguia explicar a decisão adotada pela empresa nas situações estudadas. Caso a resposta do modelo fosse satisfatória, assumiu-se que o modelo poderia explicar a decisão tomada, representando também o nível de importância de cada aspecto avaliado em um determinado contexto.

\subsection{Método usado na questão de pesquisa Q3}

A parte do estudo que diz respeito a questão de pesquisa Q3 (Considerando os aspectos de decisão levantados na literatura, qual o nível de importância de cada um deles para as empresas brasileiras que passaram pelo processo de terceirização de suas funções de $\mathrm{TI}$ e qual a inter-relação entre estes fatores?) possuía caráter exploratório, ou seja, o de verificar se existiam indícios de que as empresas brasileiras consideraram em seus processos de decisão, de uma forma geral, que alguns aspectos de decisão foram mais importantes do que outros. Principalmente, esta parte do estudo teve por objetivo verificar, com base no nível de importância adotado pelas empresas, se havia inter-relacionamento entre os aspectos, validando ou questionando o inter-relacionamento encontrado na literatura (conforme apresentado na seção 1.2). Nesta análise, os aspectos de decisão de terceirização foram considerados como variáveis independentes. 
O método de coleta de dados utilizado nesta parte foi o survey. De acordo com Forza (2002) o survey pode ser utilizado como método de pesquisa para estudos exploratórios. A metodologia utilizada neste estudo seguiu, em linhas gerais, os passos também propostos por Forza (2002). Em primeiro lugar, se procurou o estabelecer uma ligação entre a teoria e o que está se querendo estudar. Isso foi feito usando como base a pesquisa bibliográfica onde foram desenvolvidos os construtos utilizados nesta pesquisa.

De posse das informações sobre os dados que precisariam ser coletados, juntamente com os objetivos do estudo, passou-se para o processo de desenvolvimento do formulário para a coleta dos dados. Este formulário foi composto por 20 questões divididas em três grupos (ver anexo B). O primeiro grupo tratava do levantamento de informações para contato. O segundo grupo buscava as informações das empresas respondentes. O terceiro grupo tratava da verificação da consideração dos aspectos discutidos, assim como a determinação do nível de importância destes aspectos de acordo com a opinião dos respondentes. Cabe ressaltar que este terceiro grupo tratava apenas do levantamento das informações relacionadas às variáveis independentes analisadas nesta parte. Para que as perguntas pertencentes a este terceiro grupo fossem devidamente respondidas, cada um dos aspectos de decisão foi detalhado por meio de um quadro. Aos respondentes foi solicitado que o quadro com a descrição dos aspectos fosse lido e entendido antes que as perguntas fossem respondidas.

O formulário mencionado foi ainda validado por dois profissionais de $\mathrm{Tl}$ com ampla experiência em terceirização de TI (o gerente de TI de uma empresa de geração de energia elétrica e o diretor de TI de uma empresa de telecomunicações), de acordo com as recomendações apresentadas por Forza (2002). O aspecto principal avaliado por estes dois profissionais foi a clareza do formulário, no que concerne ao levantamento das informações necessárias. Após a avaliação destes dois profissionais o formulário foi re-modelado e enviado aos respondentes.

O formulário foi enviado para aproximadamente 400 profissionais de TI. Dos formulários enviados, apenas 6,75\% foram respondidos em duas chamadas. A segunda solicitação de participação da pesquisa teve um índice de resposta superior 
a primeira. Os dados obtidos com o índice de respostas mencionado acima tratam de uma amostra de conveniência (TRIOLA, 1999).

O método usado para analisar os dados coletados pode ser dividido em duas partes. Primeiramente, utilizou-se estatística descritiva. Estatística descritiva pode ser considerada como um método que apresenta e descreve tabelas e gráficos, podendo ser usada em vários tipos de estudo, inclusive nos estudos exploratórios (FREUND; SIMON, 2000). A análise por estatística descritiva usou, neste estudo, gráficos em coluna para apresentar médias e percentagens, com o objetivo de buscar informações iniciais.

A segunda parte do estudo usou correlação para avaliar se os aspectos de decisão de terceirização de $\mathrm{TI}$ propostos poderiam estar inter-relacionados conforme descrito pela literatura. A correlação é uma técnica de análise estatística usada para verificar se uma variável pode estar relacionada com outra (TRIOLA, 1998). Com esta análise, esta parte do estudo pôde verificar se os aspectos de decisão poderiam estar relacionados entre si. Com esta informação, discutiu-se o inter-relacionamento apresentado na literatura e se revisitou o modelo apresentado na anteriormente.

Tabela 3.1 - Variáveis utilizadas na análise estatística da questão de pesquisa Q3.

\begin{tabular}{|c|c|c|}
\hline Descrição & Código & Valores \\
\hline $\begin{array}{l}\text { Questões estratégicas devem ser consideradas na } \\
\text { decisão? }\end{array}$ & A1 & \multirow[t]{6}{*}{$\begin{array}{l}1=\operatorname{Sim} \\
2=\mathrm{Não}\end{array}$} \\
\hline Custos devem ser considerados na decisão? & A2 & \\
\hline $\begin{array}{l}\text { O perfil do profissional de TI deve ser considerado } \\
\text { na decisão? }\end{array}$ & A3 & \\
\hline Os riscos devem ser considerados na decisão? & A4 & \\
\hline Contratos devem ser considerados na decisão? & A5 & \\
\hline Benchmarking deve ser considerado na decisão? & A6 & \\
\hline $\begin{array}{l}\text { Nível de importância do aspecto questões } \\
\text { estratégicas }\end{array}$ & B1 & \multirow{6}{*}{$\begin{array}{l}1=\text { Sem importância } \\
2=\text { Menos importante } \\
3=\text { Importante } \\
4=\text { Muito importante } \\
5=\text { Necessário }\end{array}$} \\
\hline Nível de importância do aspecto custo & B2 & \\
\hline Nível de importância do aspecto perfil profissional & B3 & \\
\hline Nível de importância do aspecto risco & B4 & \\
\hline Nível de importância do aspecto contratos & B5 & \\
\hline Nível de importância do aspecto benchmarking & B6 & \\
\hline
\end{tabular}

As variáveis utilizadas nas análises estatísticas para responder à questão de pesquisa Q3 são todas independentes. As variáveis com código AN (onde N é um 
número inteiro que varia de 1 a 6) são classificadas por Hair et al (1998) como nãométricas e por Triola (1999) como bi-nominais. As variáveis com código BN (onde $\mathrm{N}$ é um número inteiro que varia de 1 a 6) são classificadas por Hair et al (1998) como métricas e por Triola (1999) como ordinais. A descrição, os códigos e os valores que tais variáveis podem assumir são apresentados na tabela 3.1.

\subsection{Método usado na questão de pesquisa Q4}

Finalmente, o método de coleta de dados utilizado para responder a esta a questão de pesquisa Q4 (Quais são os fatores externos que podem influenciar no nível de importância dos aspectos de decisão de terceirização de funções de Tl e que tipo de influência eles trazem?) foi também o survey. Da mesma maneira que no item anterior, as linhas gerais propostas por Forza (2002) também foram seguidas. Os construtos utilizados na pesquisa também foram compostos com a revisão bibliográfica.

De posse das informações sobre os dados que precisariam ser coletados, juntamente com os objetivos do estudo, passou-se para o processo de desenvolvimento do formulário para a coleta dos dados. Este formulário foi composto por 40 questões divididas em sete grupos (ver anexo C). O primeiro grupo tratava do levantamento de informações para contato. O segundo grupo buscava as informações das empresas respondentes. O terceiro grupo tratava da verificação da consideração dos aspectos discutidos, assim como a determinação do nível de importância destes aspectos de acordo com a opinião dos respondentes. O nível de importância foi levantado através de uma escala de 0 a 10 onde 0 representa um aspecto menos importante e 10 representa um aspecto mais importante. Cabe ressaltar que este terceiro grupo tratava apenas do levantamento das informações relacionadas às variáveis dependentes analisadas nesta parte. Para que as perguntas pertencentes a este terceiro grupo fossem devidamente respondidas, 
cada um dos aspectos de decisão foi detalhado por meio de um quadro. Aos respondentes foi solicitado que o quadro com a descrição dos aspectos fosse lido e entendido antes que as perguntas fossem respondidas.

O quarto grupo tratava do levantamento do nível de financeirização para as empresas com capital aberto. Para tanto, cinco perguntas relativas a financeirização foram feitas. O quinto grupo tratava do levantamento do nível hierárquico do respondente assim como do perfil desse profissional. Para que tal nível pudesse ser medido, foram feitas cinco perguntas dentro dessa temática. O sexto grupo tratava do mapeamento do papel da TI na organização do respondente. Esse mapeamento foi feito questionando o respondente sobre características da área de TI de acordo com os quadrantes do grid estratégico de Nolan e McFarlan (2005). Note-se que o intuito deste trabalho não é o de posicionar as empresas pesquisas dentro dos quadrantes de referência utilizados, mas sim o de avaliar como o aumento do nível em cada uma dos fatores externos pode mudar o nível de importância dos aspectos de decisão. Logo, os resultados utilizados nesta pesquisa não enquadram as empresas pesquisadas de acordo com o grid, mas sim apontam para àquelas em que a TI possui maior importância estratégica em um determinado grau. Finalmente, o quinto grupo tratava da verificação do nível de alinhamento estratégico entre a TI e o negócio. O nível de alinhamento foi medido perguntando ao respondente sobre a ocorrência dos fatores catalisadores do alinhamento de acordo com o proposto por Luftman; Papp e Brier (1996).

Os grupos quatro, cinco, seis e sete tratam das variáveis independentes desse estudo. Cada uma das variáveis representadas nestes últimos quatro grupos foi transformada em uma escala numérica pela média da pontuação que cada resposta a pergunta inserida em seu grupo recebeu, embora algumas delas sejam binárias e outras, escalas. Por exemplo, para medição da importância estratégica da TI de acordo com Nolan e McFarlan (2005), cada resposta positiva ao impacto estratégico da TI representa um incremento de $20 \%$ na importância estratégica da TI na organização respondente. Dessa maneira, cada um destes quatro últimos grupos assumiu valores em uma escala que varia de 0 a 10, da mesma forma como as variáveis dependentes descritas no grupo de perguntas três. Essa transformação 
para escala numérica de 0 a 10 se justifica pelo método de análise estatística escolhido para esta parte da pesquisa.

A ferramenta de análise estatística escolhida para esta parte do trabalho é o de regressão. A regressão se utiliza de modelos probabilísticos, uma vez que sua resposta exibe variabilidade. Além disso, tais modelos são normalmente compostos por elementos aleatórios, ou que sofrem influência de forças aleatórias (MYERS; MONTGOMERY; VINING, 2001). O uso de regressão se justificou, pois é capaz de responder ao questionamento sobre quais forças podem influenciar no nível de importância dos aspectos de decisão de terceirização em TI e como tais forças alteram o nível de importância destes aspectos.

O modelo de regressão adotado foi 0 linear na forma de $y_{n}=\beta_{n .0}+\beta_{n .1} \cdot x_{1}+\beta_{n .2} \cdot x_{2}+\beta_{n .3} . x_{3}+\beta_{n .4} \cdot x_{4}$, onde $n$ é um número inteiro que varia de 1 a 6, representando cada um dos aspectos de decisão de terceirização de TI. $y_{n}$ representa o valor do nível de importância de cada aspecto de decisão de terceirização de TI. $B_{n .0}$ representa o valor do parâmetro desconhecido para a interseção para cada aspecto de decisão de terceirização de TI. $B_{n .1}$ representa o valor do parâmetro desconhecido para a variável independente relativa a financeirização para cada aspecto de decisão de terceirização de TI. $B_{n .2}$ representa o valor do parâmetro desconhecido para a variável independente relativa ao nível hierárquico para cada aspecto de decisão de terceirização de $\mathrm{TI}$. $B_{n .3}$ representa o valor do parâmetro desconhecido para a variável independente relativa ao papel da TI na organização para cada aspecto de decisão de terceirização de TI. E, $B_{n .4}$ representa o valor do parâmetro desconhecido para a variável independente relativa ao nível de alinhamento entre a TI e o negócio para cada aspecto de decisão de terceirização de TI. A regressão em questão foi realizada utilizando o software Minitab, regressão Stepwise. A regressão Stepwise adiciona e remove variáveis ao modelo de regressão até que se identifique o melhor grupo de parâmetros desconhecidos. $O$ índice observado para a análise dos modelos de regressão foi o $\mathrm{R}^{2}$. O percentual descrito no valor de $\mathrm{R}^{2}$ significa o percentual de variação explicado pela regressão apresentada (MYERS; MONTGOMERY; VINING, 2001) 
Assim como ocorreu com a questão de pesquisa Q3, o formulário com as perguntas foi validado por dois profissionais de TI com ampla experiência em terceirização de TI (o gerente de TI de uma empresa de geração de energia elétrica e o diretor de TI de uma empresa de telecomunicações), de acordo com as recomendações apresentadas por Forza (2002). O aspecto principal avaliado por estes dois profissionais foi a clareza do formulário, no que concerne ao levantamento das informações necessárias. Após a avaliação destes dois profissionais o formulário foi re-modelado e enviado aos respondentes.

Tabela 3.2 - Variáveis utilizadas na análise estatística da questão de pesquisa Q4.

\begin{tabular}{|c|c|c|}
\hline Descrição & Código & Valores \\
\hline $\begin{array}{l}\text { Nível de importância do aspecto } \\
\text { questões estratégicas }\end{array}$ & A1 & \multirow{6}{*}{$\begin{array}{l}\text { De } 0 \text { a } 10 \text { onde } 0 \text { representa } \\
\text { nenhuma importância e } 10 \\
\text { representa importância } \\
\text { fundamental }\end{array}$} \\
\hline Nível de importância do aspecto custo & $\mathrm{A} 2$ & \\
\hline $\begin{array}{l}\text { Nível de importância do aspecto perfil } \\
\text { profissional }\end{array}$ & A3 & \\
\hline Nível de importância do aspecto risco & A4 & \\
\hline $\begin{array}{l}\text { Nível de importância do aspecto } \\
\text { contratos }\end{array}$ & A5 & \\
\hline $\begin{array}{l}\text { Nível de importância do aspecto } \\
\text { benchmarking }\end{array}$ & A6 & \\
\hline $\begin{array}{l}\text { Nível de influência que a } \\
\text { financeirização exerce sobre a } \\
\text { empresa pesquisada }\end{array}$ & $\mathrm{B}$ & $\begin{array}{l}\text { De } 0 \text { a } 10 \text { onde } 0 \text { representa } \\
\text { nenhuma influência e } 10 \\
\text { representa total influência }\end{array}$ \\
\hline $\begin{array}{l}\text { Nível hierárquico do profissional que } \\
\text { decide pela terceirização das funções } \\
\text { de TI, associado ao perfil } \\
\text { transformador }\end{array}$ & $\mathrm{C}$ & $\begin{array}{l}\text { De } 0 \text { a } 10 \text { onde } 0 \text { representa baixo } \\
\text { nível e sem influência de } \\
\text { transformação e } 10 \text { representa } \\
\text { alto nível com alta influência de } \\
\text { transformação }\end{array}$ \\
\hline Papel da TI na organização & $\mathrm{D}$ & $\begin{array}{l}\text { De } 0 \text { a } 10 \text { onde } 0 \text { representa } \\
\text { papel de suporte e } 10 \text { representa } \\
\text { papel estratégico }\end{array}$ \\
\hline Alinhamento entre a TI e o negócio & $E$ & $\begin{array}{l}\text { De } 0 \text { a } 10 \text { onde } 0 \text { representa } \\
\text { nenhum alinhamento e } 10 \\
\text { representa alinhamento total }\end{array}$ \\
\hline
\end{tabular}

As variáveis utilizadas nas análises estatísticas para responder à questão de pesquisa Q4 são classificadas como dependentes e independentes. As variáveis com código $\mathrm{AN}$ (onde $\mathrm{N}$ é um número inteiro que varia de 1 a 6) são as variáveis dependentes do estudo e classificadas por Hair et al (1998) como métricas e por Triola (1999) como ordinais. As variáveis com código B, C, D e E são as variáveis 
independentes do estudo e também classificadas por Hair et al (1998) como métricas e por Triola (1999) como ordinais. A descrição, os códigos e os valores que tais variáveis podem assumir são apresentados na tabela 3.2. 


\section{APRESENTAÇÃO E DISCUSSÃO DOS DADOS OBTIDOS}

No que diz respeito a questão de pesquisa Q1, com base na revisão da literatura sobre terceirização das funções da Tecnologia da Informação (TI) é possível verificar que a decisão de terceirização leva em conta seis aspectos básicos: (1) questões estratégicas; (2) custos; (3) riscos; (4) contratos; (5) benchmarking e; (6) perfil dos profissionais de TI. Também de acordo com a literatura, esses aspectos se interrelacionam entre si.

Os seis aspectos e suas inter-relações apresentadas na literatura podem ser modelados em uma árvore de decisão hierárquica e então entrados em um software de simulação ANP de modo a se verificar, numericamente, o nível de importância de cada aspecto em determinadas decisões de terceirização de TI. A figura 4.1 apresenta a árvore de decisão hierárquica com os aspectos e suas inter-relações.

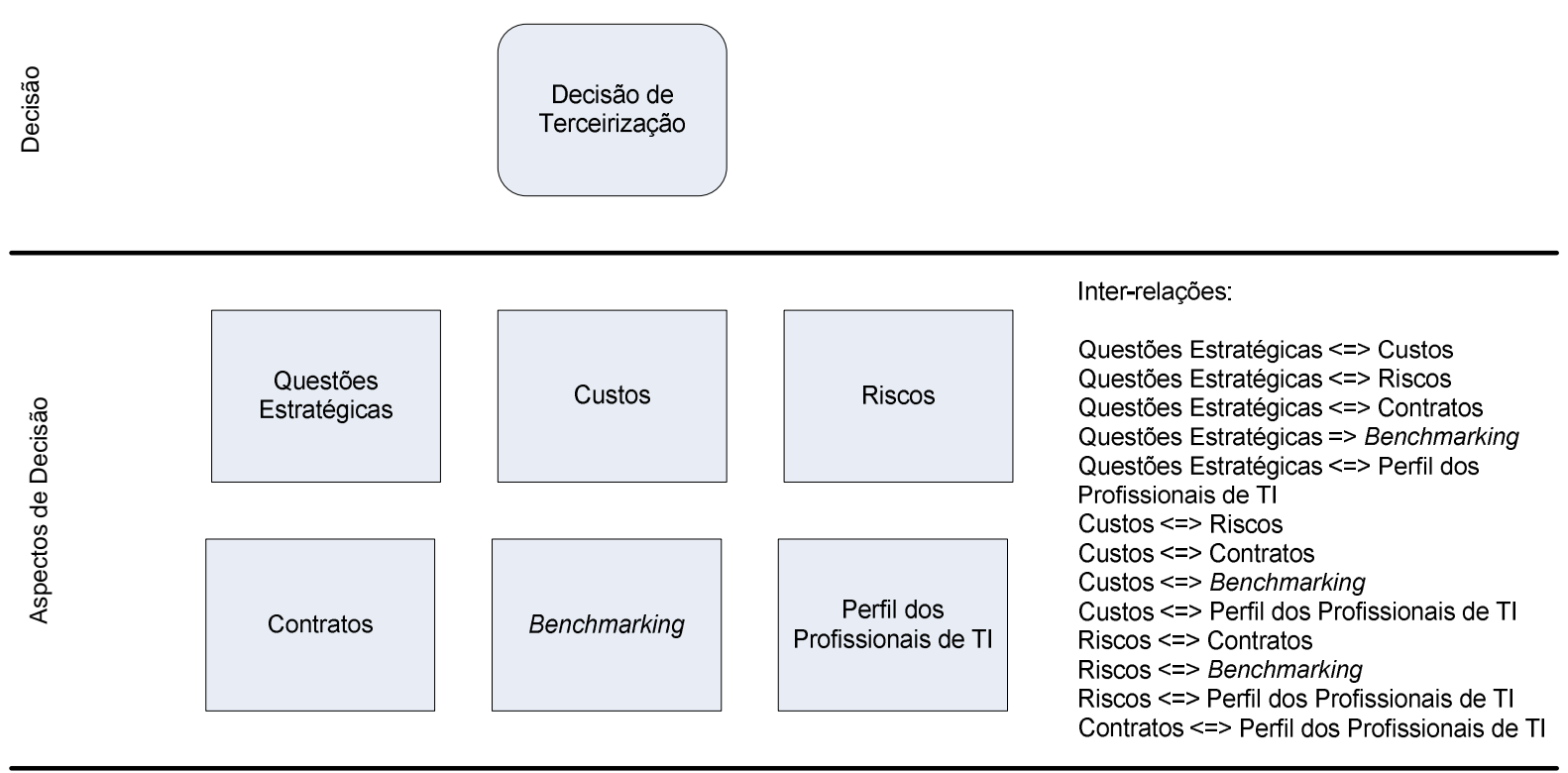

Figura 4.1 - Modelo de pesquisa, árvore de decisão hierárquica com os aspectos de decisão e suas inter-relações 
No ato da decisão, cada um destes aspectos possui um nível de importância distinto. De uma maneira geral, para as empresas brasileiras, haverá uma escala de importância para estes aspectos. Entretanto, existem alguns aspectos que contribuem de forma isolada e outros que se inter-relacionam durante o processo de tomada de decisão adotado pelas empresas. Utilizando-se da ferramenta estatística de correlação, é possível verificar se o inter-relacionamento entre estes aspectos descrito na literatura ocorre no cenário das empresas brasileiras, quando considerado o nível de importância de cada aspecto no processo de tomada de decisão.

Finalmente, se há variações na escala de importância dos aspectos considerados na decisão de terceirização de funções de $\mathrm{Tl}$, é porque existem fatores que influenciam o nível de importância de cada aspecto nos momentos de decisão. Quatro fatores podem influenciar o nível de importância dos aspectos de decisão. O fenômeno da financeirização e suas implicações fazem com que os níveis de importância dos aspectos sejam diferentes entre empresas. O nível hierárquico do profissional responsável pela decisão de terceirizara função da TI, e seu perfil profissional, faz com que os níveis de importância dos aspectos sejam diferentes entre empresas. A diferença do papel da $\mathrm{Tl}$ entre as empresas é um fator que muda a escala de importância dos aspectos de decisão de terceirização de funções de Tl entre as empresas. A diferença no nível de alinhamento entre a $\mathrm{TI}$ e o negócio nas organizações também implica em mudanças na escala de importância dos aspectos para diferentes empresas.

As seções a seguir apresentam os dados obtidos nas pesquisas realizadas para responder às questões de pesquisa subseqüentes. 


\subsection{Modelo inicial de pesquisa simulado no ANP}

As situações de terceirização estudadas fazem parte da experiência de uma empresa brasileira do setor de energia elétrica que possui um faturamento anual de aproximadamente 110 milhões de reais e conta com a colaboração de 450 funcionários, onde 150 destes são usuários dos sistemas de TI. A área de $\mathrm{TI}$ da empresa conta com a colaboração de oito funcionários, tendo um orçamento de aproximadamente 2 milhões de reais para investimentos e cerca de 800 mil reais para custos com a operação de suas funções. Segundo informações levantadas junto ao gerente da área de TI, as práticas de gestão da área de TI são atualizadas, sendo usado o que há de mais novo dentre as práticas de mercado.

Embora a área de TI preste diversos serviços para os seus usuários, ela não possui massa significativa de serviços para a obtenção de, por exemplo, ganhos com escala. Desta forma, o gerente de TI considera que o nível de terceirização desta área pode ser enquadrado entre médio e alto. Dos componentes de $\mathrm{TI}$, usando a tipologia de Loff (1997), normalmente se opta pela terceirização de hardware, software e pessoas, sendo os procedimentos e dados de responsabilidade interna. Outro fator que causa um impacto direto nas decisões de terceirização diz respeito a visão da TI pela diretoria da empresa. A diretoria de empresa, por não considerar a atividade de TI como fim da empresa, opta por terceirizar o que for possível. Logo, de acordo com McFarlan (1984), para essa empresa a TI não se coloca no quadrante estratégico. Por este motivo, alguns sistemas de informação que suportam as atividades fim da empresa também são terceirizados, também usando a tipologia de Loof (1997). No que diz respeito as atividades terceirizadas da área de TI, opta-se por buscar no mercado a operação, manutenção, implementação e desenvolvimento de serviços de TI, uma vez que o custo de se fazer isso é, na visão do gerente de $\mathrm{TI}$ da empresa, mais baixo do que o custo necessário para o desenvolvimento interno das competências envolvidas nestas atividades. Atividades de planejamento da área de TI são executadas internamente por questões estratégicas. 


\subsubsection{Situação 1}

A primeira situação trata da terceirização da armazenagem, administração e manutenção de um sistema integrado de gestão (ERP) na modalidade Application Service Provider (ASP). Segundo a empresa prestadora do serviço, "ASP é um serviço onde a empresa terceira (nome retirado para fins de sigilo) fornece e administra os seus aplicativos de gestão empresarial através de um contrato de prestação de serviço com uma mensalidade fixa. Estes aplicativos ficam hospedados em um datacenter, onde toda infra-estrutura tecnológica (servidores, software de base, backup das informações, monitoração, energia, climatização, segurança, vigilância, equipamentos de rede, telecomunicações, serviços de manutenção e os recursos humanos a estes associados) é parte integrante do serviço". Como dito, a operação do sistema é feita pela empresa terceira, sendo o uso do sistema feito pela empresa cliente.

Nesta situação, a empresa estudada precisou fazer um investimento em infraestrutura de TI para que fosse possível terceirizar o serviço em questão. Caso esse investimento não fosse feito, não seria possível, do ponto de vista técnico, operar o serviço ERP desta maneira. Esse investimento inicial foi de aproximadamente 40 mil reais. O custo mensal desse serviço terceirizado é de aproximadamente 39 mil reais. Cabe ressaltar que esse sistema, atualmente, suporta diversas atividades da empresa, entre elas, atividades fim.

No que diz respeito ao processo de decisão da terceirização deste serviço, a empresa tentou fazer com que a decisão fosse apoiada por um método estruturado. Análises de custo, levando em conta os custos de operação interna e de contratação do serviço; e de risco, envolvendo problemas relacionados a operação do serviço e de garantias do fornecedor, foram consideradas para que um cenário fosse montado e a decisão, só então, tomada. 


\subsubsection{Situação 2}

A segunda situação trata da terceirização de pessoas, em outras palavras, da obtenção de conhecimento específico no mercado, isto é, terceirização estratégica de acordo com Quinn e Hilmer (1994). Com a implementação do sistema mencionado acima, surgiu a demanda de desenvolvimento de aplicações específicas vinculadas ao sistema ERP (ex: relatórios). A área de TI não possuía a competência, conhecimento, necessária para o desenvolvimento destas aplicações. Logo, existiam duas opções para que ela pudesse atender aos seus usuários. "Poderíamos formar algumas pessoas dentro da área ou buscar pessoas com conhecimento comprovado para nos ajudar nessa tarefa. Como precisávamos disso com certa urgência, e como os custos para a formação das pessoas internas era mais alto, optamos por terceirizar", descreve o gerente de TI da empresa estudada. Nesse caso, e em todos os outros, a questão do custo teve um peso considerável na decisão a ser tomada.

\subsubsection{Situação 3}

A terceira situação trata da terceirização do desenvolvimento e da manutenção de um sistema de informação. Esse sistema atende a uma das atividades fim da empresa estudada, a de controle de produção de energia e relatórios gerenciais para os clientes da empresa. O desenvolvimento e a manutenção do sistema em questão foram terceirizados como uma empresa que possuía uma parceria antiga com a empresa estudada. Nota-se aqui o papel da confiança no processo de 
decisão e seu impacto na importância dos aspectos, conforme destacado por Humphrey e Schmitz (1998). Essa parceria trouxe a tona um comportamento diferenciado do ponto de vista da decisão de terceirização. Mesmo com a relevância estratégica do sistema em questão, a parceria fez com que a empresa desse foco, mais uma vez, à questão prática da terceirização (uma vez que a empresa não possuía conhecimento técnico para o desenvolvimento do sistema) e aos custos, deixando de lado a análise de riscos. Tanto o valor investido no inicio deste projeto, quanto o valor mensal para a operação desse serviço terceirizado são baixos em relação ao orçamento total da TI na empresa estudada.

\subsubsection{Resultado e discussão das simulações}

Conforme mencionado na metodologia, esse estudo simula o modelo proposto nas três situações da empresa estudada. Desta forma, o modelo em questão foi inserido no software Super Decisions e em seguida, uma simulação foi realizada com o gerente de $\mathrm{TI}$ da empresa estudada de maneira que ele pudesse pontuar os diversos critérios e alternativas dos três casos em conformidade com a operacionalização do método ANP. O resultado destas três simulações é apresentado nas figuras que se seguem.

Faz-se importante ressaltar que as simulações feitas com o modelo proposto no método ANP são complexas e demoradas. Complexas, porque a comparação entre os aspectos da decisão exigida pelo método é abstrata, demandando um nível de concentração elevado e um cuidado excessivo para que não se faça confusão entre as diversas comparações semelhantes. Por exemplo, devido a inter-relação entre os critérios da decisão custo e risco com todos os outros critérios, faz-se necessário definir a importância relativa dos dois para cada um dos critérios que causam impactos a eles. Em função destes inter-relacionamentos entre os aspectos e da 
comparação ponto-a-ponto exigida pelo método ANP, o lançamento dos dados para a simulação se torna demorado.

Em relação a simulação feita com os dados da primeira situação (o resultado da simulação da situação 1 é apresentado na figura 4.2), segundo o gerente de TI da empresa estudada, o resultado está aderente com a decisão tomada, uma vez que a decisão não teve influência significativa do aspecto custo, mas sim dos aspectos estratégicos e do perfil do profissional de TI. Estratégico, porque a empresa não possuía o conhecimento necessário para implementar e administrar um serviço de $\mathrm{TI}$ crítico e com tantos detalhes técnicos, aderente a discussão proposta por Quinn e Hilmer (1994) sobre terceirização estratégica. Portanto, para que ela pudesse ter estes serviços operando de uma maneira adequada, ela precisou buscar no mercado uma empresa de porte que prestasse o serviço em questão com um nível de disponibilidade elevado.

No que diz respeito ao perfil do profissional de $\mathrm{TI}$, a área de $\mathrm{TI}$ da empresa estudada não possuía profissionais com o perfil técnico, mas sim com o perfil administrativo. Em outras palavras, os profissionais de $\mathrm{TI}$ da empresa estudada tinham competências mais voltadas para a administração de contratos do que para a operação técnica de sistemas de TI. Em outras palavras, a empresa estudada parece estar alinhada com o estudo de Bullen et al (2007). Cabe ressaltar que o aspecto custo teve relevância na decisão, embora ele não tenha sido 0 critério definitivo para a tomada de decisão. Conforme destacado por vários autores, o aspectos custo é normalmente avaliados em decisões desta natureza. O nível de importância desse aspecto também foi confirmado pelo gerente de TI da empresa estudada.

Sobre os outros aspectos, eles tiveram menor relevância porque eram desconhecidos naquele momento. Por exemplo, até o momento da entrevista, o gerente de $\mathrm{Tl}$ da empresa estudada mencionou que não considerava o aspecto contrato na decisão, embora ele reconhecesse sua importância. Portanto, no que diz respeito a situação 1 , o modelo proposto conseguiu explicar a decisão efetivamente tomada ao quantificar o nível de importância de cada aspecto adotado na decisão. 


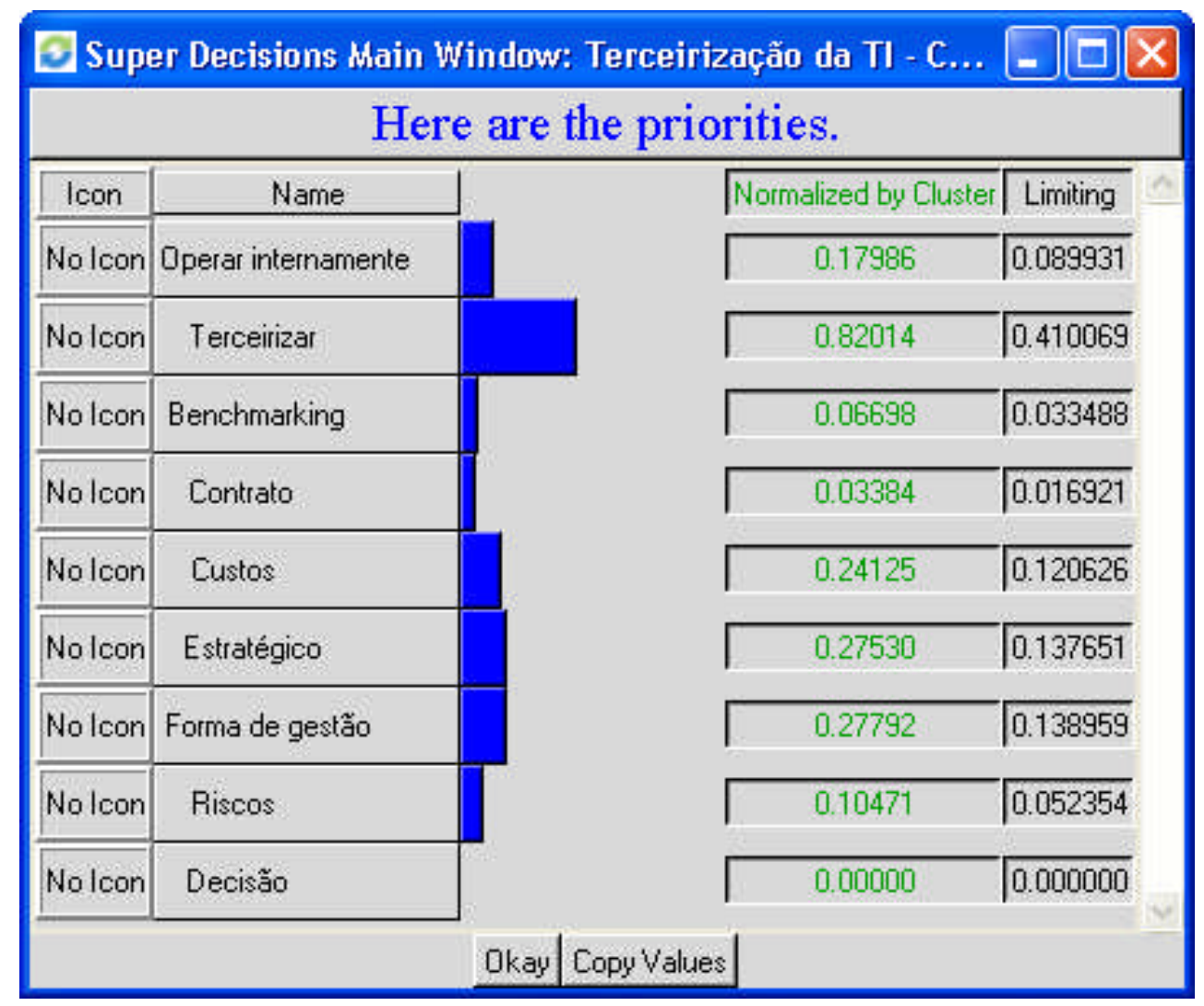

Figura 4.2 - Resultado da simulação do caso 1.

Para a situação 2 (o resultado da simulação da situação 2 é apresentado na figura 4.3), a simulação apresentou um resultado aderente à decisão feita anteriormente pela empresa estudada. Embora o perfil do profissional de $\mathrm{TI}$ fosse um aspecto importante, do ponto de vista do gerenciamento da área com a competência necessária para o desenvolvimento da atividade, o aspecto custo foi definitivo na tomada de decisão. Conforme mencionado na descrição do caso, os custos necessários para a formação interna da competência em questão eram elevados demais se comparados com o custo de obtenção do conhecimento no mercado. Portanto, no que diz respeito a situação 2, o modelo proposto também conseguiu explicar a decisão efetivamente tomada ao quantificar o nível de importância dos aspectos considerados naquela decisão. 


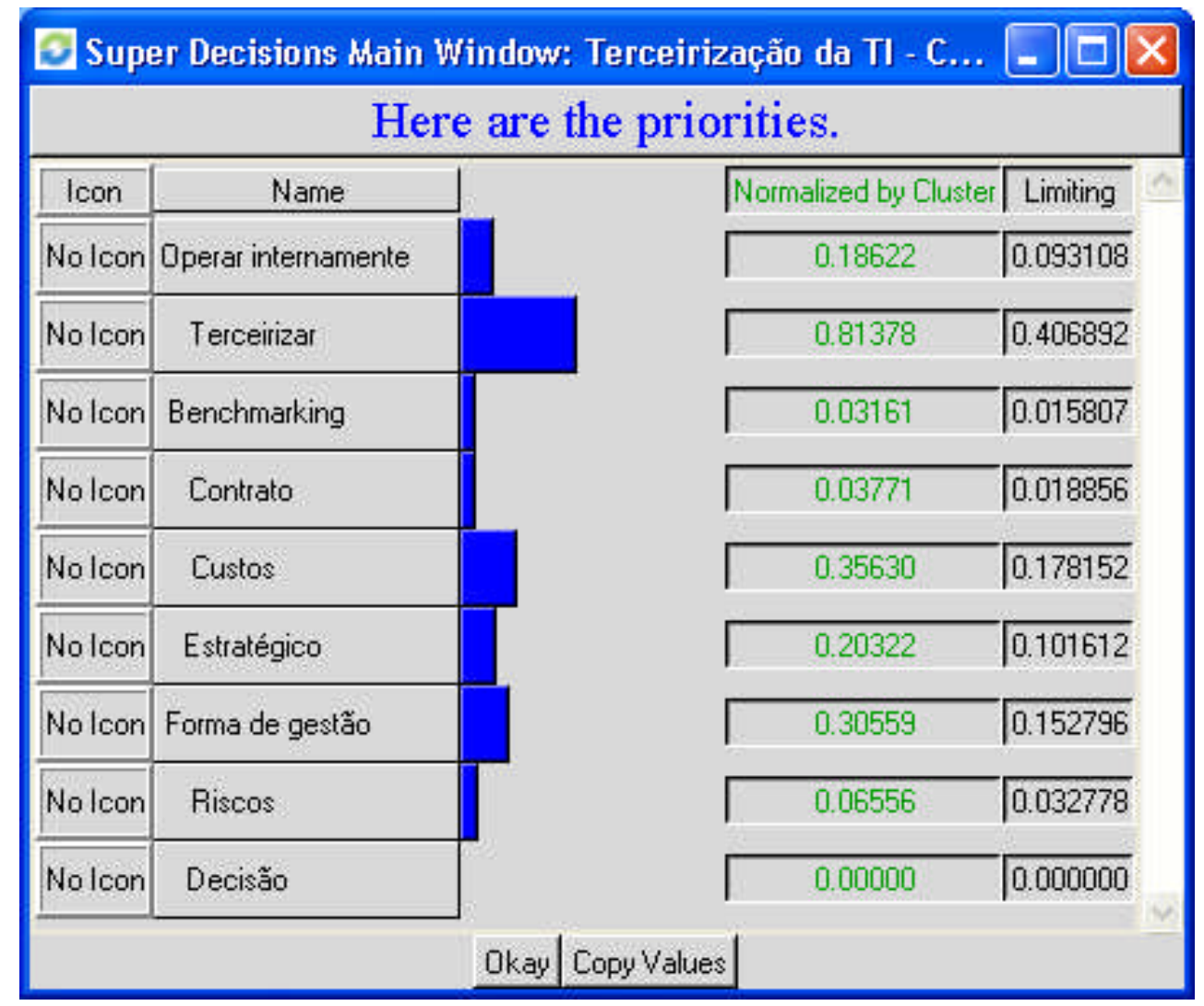

Figura 4.3 - Resultado da simulação do caso 2.

Quanto a situação 3 (o resultado da simulação da situação 3 é apresentado na figura 4.4), o motivo pelos quais os aspectos risco e contrato apresentaram baixa relevância, explica-se pelo fato da empresa estudada já ter uma parceria antiga com a empresa terceira. Nota-se então a questão da confiança entre as partes conforme descrito por Humphrey e Schmitz (1998). Tal parceria trouxe confiança ao relacionamento entre estes atores sem que fosse necessário um contrato bem feito e uma análise de risco elaborada.

Do ponto de vista dos aspectos decisivos para a decisão, custo de fato era o mais relevante uma vez que foi o critério definitivo para a decisão. Além disso, a empresa não tinha competência interna para o desenvolvimento, e a formação desta competência significaria um custo maior. O motivo que levou o aspecto estratégico a ter sido colocado em segundo lugar diz respeito à importância estratégica e operacional do sistema nas atividades fim da empresa. $O$ fato do perfil do profissional de $\mathrm{TI}$ aparecer freqüentemente como um dos três mais importantes se 
explica pelas competências administrativas dos profissionais da área de $\mathrm{TI}$ nesta empresa. Além disso, segundo o gerente de TI da empresa estudada, esse aspecto acompanha a tendência do alinhamento estratégico entre a TI e o negócio. Portanto, no que diz respeito ao caso 3 , o modelo proposto também conseguiu explicar a decisão efetivamente tomada ao quantificar o nível de importância dos aspectos considerados naquela decisão.

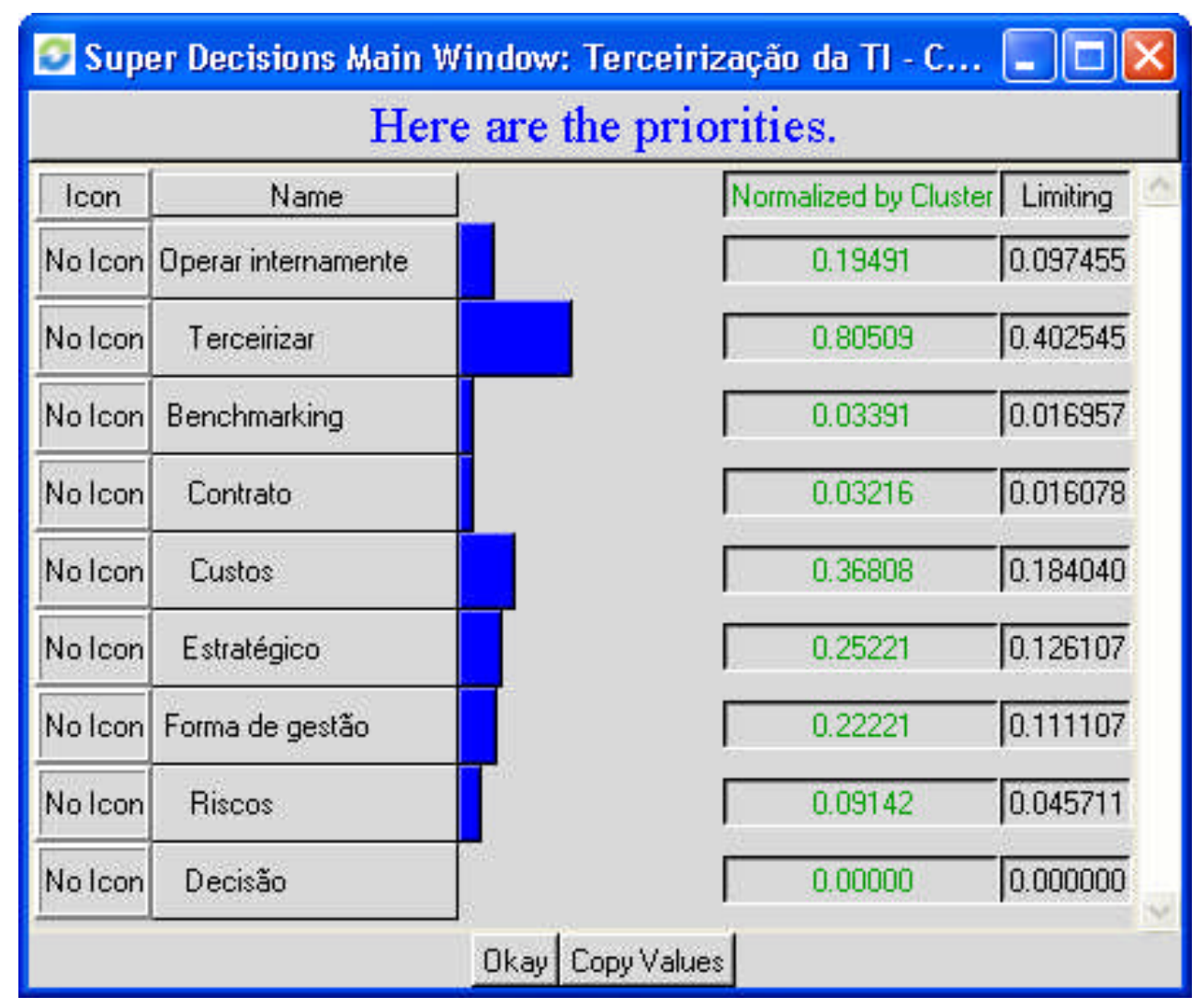

Figura 4.4 - Resultado da simulação do caso 3.

Embora o modelo tenha se mostrado aderente para as situações estudadas, questiona-se, conforme mencionado na seção 2, se o inter-relacionamento entre os aspectos verificados na literatura é, de fato, verdadeiro no contexto em que as empresas brasileiras atuam. A pergunta de pesquisa seguinte busca avaliar esta questão de modo a trazer maior robustez para o modelo proposto. 


\subsection{Importância dos aspectos de decisão e a real inter-relação entre eles no contexto das empresas pesquisadas}

A análise iniciou-se pela avaliação da distribuição das respostas de acordo com o tipo de terceirização adotado pelas empresas pesquisadas de acordo com tipologia apresentada por Loof (1997). A idéia com esta análise era verificar se havia algum desvio quanto ao tipo de terceirização praticada pelas empresas avaliadas. As figuras 4.5, 4.6, e 4.7, mostram, respectivamente, a distribuição encontrada de acordo com a tipologia de Loff (1997) para sistemas de informação, componentes e atividades.

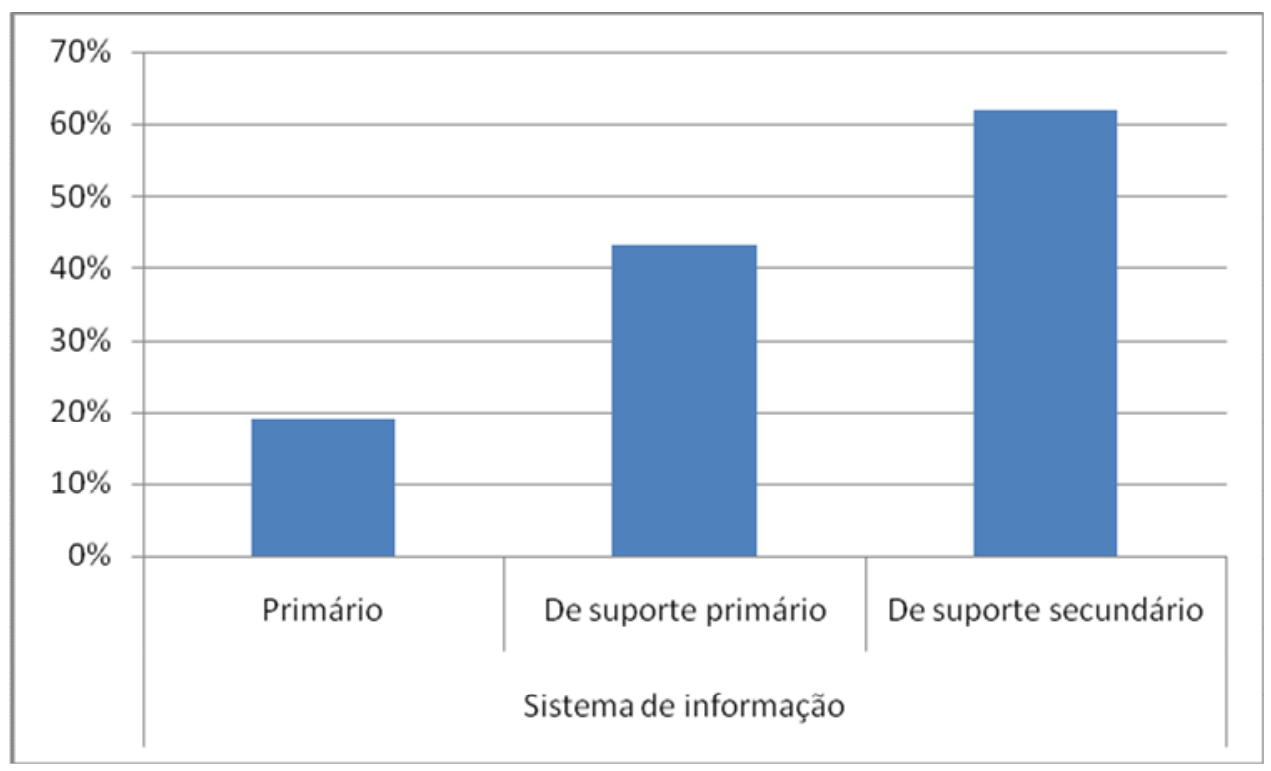

Figura 4.5 - Percentual de respostas encontradas para a tipologia de sistemas de informação de acordo com Loof (1997). 


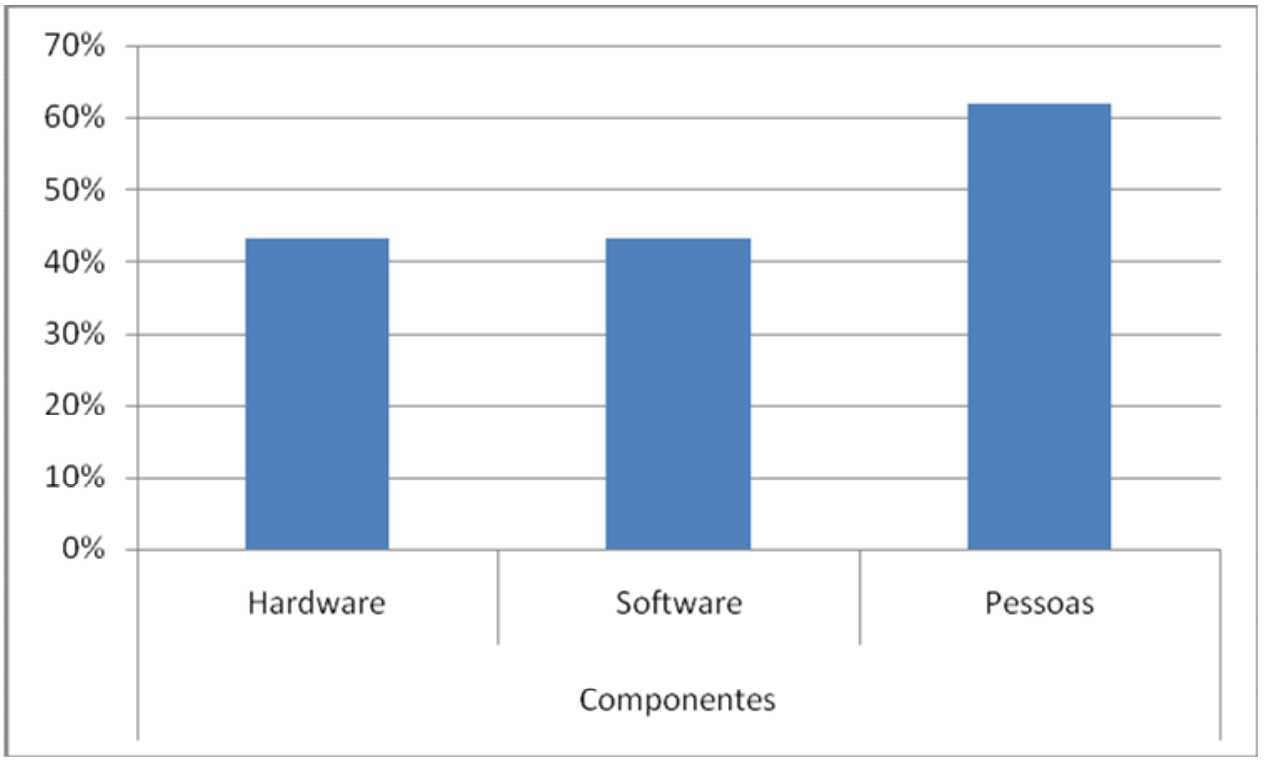

Figura 4.6 - Percentual de respostas encontradas para a tipologia de componentes de acordo com Loof (1997).

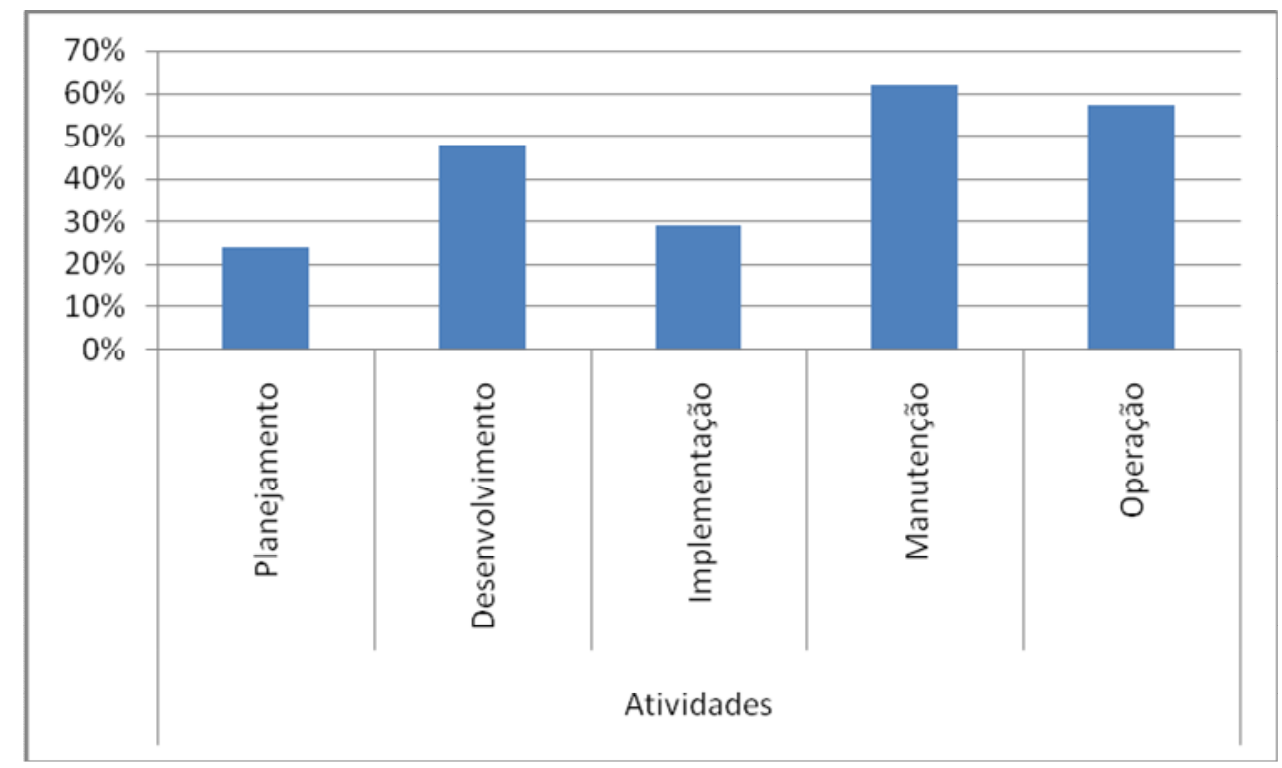

Figura 4.7 - Percentual de respostas encontradas para a tipologia de atividades de acordo com Loof (1997).

O percentual de respostas encontrado para cada item da tipologia de Loof (1997) mostra a participação de todos os tipos de terceirização na pesquisa em questão. A participação de todos os tipos de terceirização se faz importante, pois evita desvios em relação a um tipo específico de caso. Desta maneira, assume-se então que os valores encontrados para o nível de importância de cada aspecto representam de 
maneira adequada todos os tipos de terceirização apresentados na tipologia de Loof (1997). Faz-se importante colocar a existência de um conjunto interseção entre alguns itens dos grupos apresentados. Em outras palavras, nesta amostra existem, por exemplo, empresas que terceirizam componentes de hardware, software e pessoas simultaneamente.

Após a verificação da representatividade em relação a todos os tipos de terceirização, buscou-se avaliar os resultados obtidos em relação ao nível de importância dos aspectos de decisão. A tabela 4.1 apresenta os resultados obtidos para a variável AN. Pelos números apresentados nesta tabela, pode-se verificar que o aspecto questões estratégicas é mais considerado pelas empresas brasileiras. Os aspectos custos e contratos aparecem em segundo lugar com um nível de consideração de $88 \%$. Os aspectos perfil do profissional de $\mathrm{TI}$ e riscos têm seu nível de consideração pouco abaixo com $84 \%$. Finalmente, o aspecto menos considerado é o do benchmarking com $80 \%$. Faz-se importante notar que todos eles possuem um nível de consideração considerado alto.

Tabela 4.1 - Aspectos considerados na decisão de terceirização de TI (variáveis independentes A1, A2, A3, A4, A5 e A6)

\begin{tabular}{|l|l|l|}
\hline & Deve ser considerado & Não deve ser considerado \\
\hline Questões estratégicas & $96 \%$ & $4 \%$ \\
\hline Custos & $88 \%$ & $12 \%$ \\
\hline Perfil do profissional de TI & $84 \%$ & $16 \%$ \\
\hline Riscos & $84 \%$ & $16 \%$ \\
\hline Contratos & $88 \%$ & $12 \%$ \\
\hline Benchmarking & $80 \%$ & $20 \%$ \\
\hline
\end{tabular}

Informação similar a apresentada na tabela 4.1 pode ser vista na tabela 4.2 e na figura 4.8. Entretanto, tanto a informação apresentada na tabela 4.2 quanto na figura 4.8 mostra o nível de importância de cada um dos seis aspectos (variável BN). Avaliando tais informações, pode-se verificar que os aspectos questões estratégicas, custos e contratos são, em sua mediana, necessários para a avaliação da decisão de terceirização em $\mathrm{TI}$ nas empresas brasileiras. Já os aspectos riscos e perfil do profissional de TI são aspectos possuem mediana classificada como muito importante, sendo então avaliados com critério inferior os três citados anteriormente. 
Finalmente, o critério menos importante, de acordo sua mediana, na avaliação da decisão de terceirização em TI para as empresas brasileiras é o benchmarking com um nível de importância classificado como importante.

Tabela 4.2 - Nível de importância dos aspectos considerados na decisão de terceirização em TI (variáveis independentes BN).

\begin{tabular}{|l|l|l|l|l|l|}
\hline & $\begin{array}{l}\text { Sem } \\
\text { importância }\end{array}$ & $\begin{array}{l}\text { Menos } \\
\text { importante }\end{array}$ & Importante & $\begin{array}{l}\text { Muito } \\
\text { importante }\end{array}$ & Necessário \\
\hline $\begin{array}{l}\text { Questões } \\
\text { estratégicas }\end{array}$ & $0 \%$ & $4 \%$ & $8 \%$ & $24 \%$ & $64 \%$ \\
\hline Custos & $0 \%$ & $0 \%$ & $24 \%$ & $32 \%$ & $44 \%$ \\
\hline $\begin{array}{l}\text { Perfil do } \\
\text { profissional de TI }\end{array}$ & $0 \%$ & $12 \%$ & $20 \%$ & $40 \%$ & $28 \%$ \\
\hline Riscos & $0 \%$ & $0 \%$ & $12 \%$ & $56 \%$ & $32 \%$ \\
\hline Contratos & $0 \%$ & $12 \%$ & $8 \%$ & $20 \%$ & $60 \%$ \\
\hline Benchmarking & $0 \%$ & $12 \%$ & $56 \%$ & $20 \%$ & $12 \%$ \\
\hline
\end{tabular}

Comparando-se as informações obtidas nas variáveis independentes $A N$ e $B N$, verifica-se coerência entre elas uma vez que a escala de importância dos aspectos é a mesma para ambas as variáveis, mesmo uma medindo a consideração na decisão e outra medindo o nível de importância do aspecto na decisão. Logo, as respostas às duas variáveis se reforçam mutuamente, ou seja, uma variável comprova a outra e vice-versa. Desta maneira, a associação das duas variáveis cria uma seqüência em que os aspectos avaliados na decisão de terceirização de $\mathrm{TI}$ devem ser considerados e os agrupa de acordo com os seus respectivos níveis de importância. Entretanto, é possível que haja dúvidas quanto ao agrupamento dos níveis de importância ou seu inter-relacionamento, uma vez que alguns aspectos possuem níveis de importância bem distribuídos (ex: custos) em três grupos. Logo, o uso da análise de correlação entre as variáveis se faz adequado para verificar o interrelacionamento entre elas. 


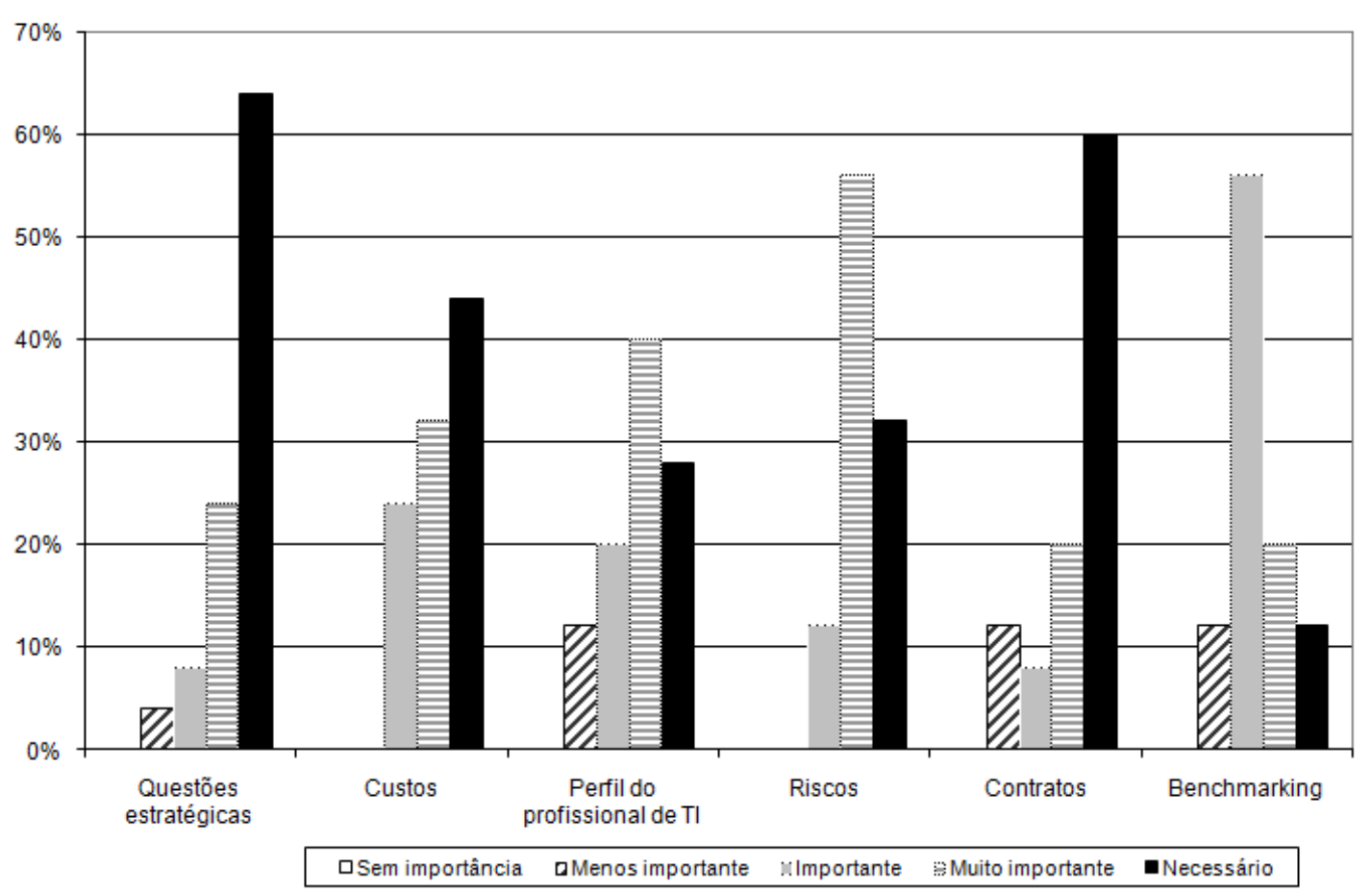

Figura 4.8 - Nível de importância dos aspectos considerados na decisão de terceirização em TI (variáveis independentes $\mathrm{BN}$ ).

Tabela 4.3 - Saída da correlação de Pearson para as variáveis independentes BN.

\begin{tabular}{|l|l|l|l|l|l|}
\hline & Estratégia & Custos & $\begin{array}{l}\text { Perfil do } \\
\text { profissional }\end{array}$ & Riscos & Contratos \\
\hline Custos & 0,384 & & & & \\
& 0,008 & & & & \\
\hline $\begin{array}{l}\text { Perfil do } \\
\text { profissional }\end{array}$ & 0,351 & 0,108 & & & \\
\hline Riscos & 0,017 & 0,474 & & & \\
& 0,001 & 0,198 & 0,462 & & \\
\hline Contratos & 0,306 & 0,186 & 0,001 & & \\
& 0,039 & 0,056 & 0,485 & 0,521 & \\
\hline Benchmarking & 0,504 & 0,121 & 0,001 & 0,000 & \\
& 0,000 & 0,424 & 0,020 & 0,621 & 0,491 \\
& & & & & \\
\hline
\end{tabular}

A análise de correlação foi feita entre as variáveis independentes BN. O método de correlação utilizado foi o Pearson. A tabela 4.3 mostra a saída total obtida no software Minitab. A tabela em questão mostra em suas células o valor da correlação Pearson na parte de cima e o valor de $\rho$ na parte da baixo. Para que se possa identificar correlação entre os aspectos analisados, buscam-se células com o valor de $\rho$ menor ou igual a 0,05 Sendo mais rigoroso quando ao teste da hipótese 
proposta, quando $\rho$ menor ou igual a 0,05 , a hipótese nula $\mathrm{H}_{0}$, correlação nula entre as variáveis, é rejeitada e a hipótese alternativa $\mathrm{H}_{1}$, há correlação entre as variáveis, é aceita. O valor de $\rho$ representa a probabilidade de cometer erros do tipo I, ou seja, de rejeitar $\mathrm{H}_{0}$ e aceitar $\mathrm{H}_{1}$ quando que o correto seria aceitar $\mathrm{H}_{0}$ e rejeitar com $\mathrm{H}_{1}$.

As informações apresentadas na tabela 4.3, confirmam o inter-relacionamento entre o aspecto questões estratégicas e todos os outros aspectos. Nesta análise, o valor de $\rho$ é inferior a 0,05 , mostrado que existem indícios da existência de correlação entre as questões estratégicas e os outros aspectos, quando considerado seu nível de importância em decisões de terceirização de funções de TI.

Em relação aos custos, a tabela 4.3 mostra que este aspecto possui um relacionamento marginal com o aspecto contratos (valor de $\rho$ aproximado de 0,05 ), mas nenhum relacionamento com outros aspectos exceto pelo aspecto de questões estratégicas. Os dados apresentados na tabela 4.3 diferem parcialmente o estudo de Aubert et al $(1996,2004)$ que diz que os custos de transação em serviços de TI terceirizados estão relacionados com diversos fatores. Conforme descrito anteriormente, o aspecto custo possui relacionamento marginal apenas com 0 aspecto contratos. Da mesma forma, os números apresentados também não estão de acordo com o estudo de Tafti (2005), o qual apresenta a relação entre custo e riscos em terceirização de TI. Os pontos contraditórios entre esta pesquisa e os trabalhos mencionados necessitam ser mais bem explorados. Uma explicação para tal contradição diz respeito ao contexto em que as empresas pesquisadas se encontravam nas referidas pesquisas, como por exemplo, o cenário competitivo, amadurecimento dos serviços de TI terceirizados, entre outros.

No que diz respeito ao perfil dos profissionais de TI, a tabela 4.3 confirma a interrelação entre este fator e os aspectos riscos e contratos descritos na literatura. Por outro lado, não confirma o possível relacionamento entre custos e o perfil do profissional de $\mathrm{TI}$, conforme mencionado na discussão sobre o aspecto custos. Entretanto, apresenta um novo relacionamento não descrito na literatura, o deste aspecto com Benchmarking. É possível explicar esse novo relacionamento avaliando o conceito dos dois aspectos. Parece natural que empresas que utilizam Benchmarking se preocupem com a questão de como os serviços terceirizados são 
administrados em outras empresas e que tipo de perfil é requerido para tal atividade. Além disso, conforme descrito por Bullen et al (2007), a questão do perfil do profissional de $\mathrm{TI}$ neste contexto está na pauta das empresas que utilizam ou pretendem utilizar serviços de $\mathrm{TI}$ terceirizados. Por se tratar de um tema contemporâneo para todas as empresas, a relevância e interesse fazem com que Benchmarking e a discussão do perfil do profissional de TI andem juntos.

Quanto ao aspecto riscos, a correlação apresentada nesta pesquisa confirma praticamente todos os inter-relacionamentos descritos na literatura, sendo ressalvado o relacionamento com o aspecto custo conforme discutido anteriormente.

Para o aspecto contratos também se confirma os inter-relacionamentos apresentado na literatura, entretanto, assim como ocorreu com o aspecto perfil dos profissionais de $\mathrm{TI}$, nota-se o estabelecimento de um relacionamento entre contratos e Benchmarking (valor de $\rho$ menor que 0,05). Embora este relacionamento não esteja explícito na literatura, Lacity e Hirschheim (1993) tratam da importância do envolvimento de consultores experientes em processos de terceirização de TI. De alguma maneira, esses profissionais trazem em seu conhecimento de outros casos semelhantes e relativos a este tipo de decisão em outras empresas. Embora não se trate de benchmarking propriamente dito, essa pode ser uma das razões de tal relacionamento. Outro fator que diz respeito a crescente preocupação com contratos em situações de terceirização de TI é o dado histórico de fracasso em situações passadas (LACITY; WILLCOCKS; FEENY, 1995). Neste contexto, parece clara a análise dos processos contratuais durante estudos de benchmarking de terceirização de funções de $\mathrm{TI}$.

Finalmente, quanto a benchmarking, todas as situações de relacionamento foram citadas nos parágrafos anteriores. Cabe então ressaltar que a análise de correlação em questão, apresentada na tabela 4.3, demonstra dois novos relacionamentos do aspecto benchmarking que não foram encontrados anteriormente na literatura. Um com risco e outro com o perfil dos profissionais de $\mathrm{TI}$ para a gestão destas operações terceirizadas. Nota-se também que o relacionamento entre benchmarking e custos não foi encontrado por esta pesquisa. 
Considerando as informações encontradas e descritas nos parágrafos acima, por meio da análise da correlação entre o nível de importância dos aspectos considerados em decisão de terceirização de TI e pesquisados em empresas brasileiras, se faz importante revistar a tabela 2.1 e propor um novo padrão de interrelacionamento para o contexto brasileiro. A tabela 4.4 apresenta este novo padrão de inter-relacionamento entre os aspectos de decisão, baseado no nível de importância considerado pelas empresas brasileiras.

Tabela 4.4 - Novo relacionamento entre os aspectos de decisão após correlação do nível de importância adotado pelas empresas brasileiras a estes.

\begin{tabular}{|l|l|l|l|l|l|l|}
\hline \multirow{2}{*}{$\begin{array}{l}\text { Aspecto } \\
\text { influenciador }\end{array}$} & \multicolumn{6}{|l|}{ Aspectos que recebem influência } \\
\cline { 2 - 7 } & Estratégico & Custo & Risco & Contratos & Benchmarking & Perfil profissional TI \\
\hline Estratégico & & X & X & X & N & X \\
\hline Custo & X & & R & X & R & R \\
\hline Risco & X & R & & X & X & X \\
\hline Contratos & X & X & X & & N & X \\
\hline Benchmarking & N & R & X & N & & N \\
\hline $\begin{array}{l}\text { Perfil } \\
\text { profissional TI }\end{array}$ & X & R & X & X & N & \\
\hline
\end{tabular}

$\mathrm{Na}$ tabela 4.4, as células com o conteúdo " $\mathrm{X}$ " são aquelas que tiveram seu relacionamento comprovado com a análise de correlação. As que possuem o valor "R" são aquelas que possuíam relacionamento de acordo com a literatura, mas não puderam ser comprovadas neste estudo. Já aquelas que possuem "N" em seu conteúdo, são aquelas onde foram encontrados novos relacionamentos após a análise de correlação entre os níveis de importância de cada aspecto avaliados por empresas brasileiras.

Para a conclusão do modelo, resta entender se algum outro fator pode influenciar no nível de importância dos aspectos de decisão em terceirização de TI. A seção a seguir tratará dessa análise e complementará o modelo de estudo. 


\subsection{Fatores que influenciam o nível de importância dos aspectos de decisão em terceirização de TI}

A tabela 4.5 apresenta a saída do software Minitab para a análise de regressão Stepwise entre as variáveis dependentes $A N$ as variáveis independentes $B, C, D$ e E.

Tabela 4.5 - Saída do software Minitab para os testes de regressão Stepwise.

\begin{tabular}{|l|l|l|l|l|l|l|}
\hline & & \multicolumn{5}{|l|}{ Variáveis independentes } \\
\hline $\begin{array}{l}\text { Variáveis } \\
\text { dependentes }\end{array}$ & $\begin{array}{l}\mathrm{R}^{2} \text { e } \mathrm{R}^{2} \\
\text { ajustado }\end{array}$ & Constante & Financeirização & $\begin{array}{l}\text { Nível } \\
\text { hierárquico }\end{array}$ & $\begin{array}{l}\text { Papel } \\
\text { da TI }\end{array}$ & $\begin{array}{l}\text { Alinhamento } \\
\text { com TI }\end{array}$ \\
\hline $\begin{array}{l}\text { Questões } \\
\text { estratégicas }\end{array}$ & $37,30 \%$ & 6,751 & & $-0,63$ & & 0,49 \\
& $30,34 \%$ & & & 0,018 & & 0,018 \\
\hline Custos & $24,05 \%$ & 9,565 & & $-0,55$ & & \\
& $20,05 \%$ & & & 0,024 & & \\
\hline $\begin{array}{l}\text { Perfil do } \\
\text { profissional }\end{array}$ & $39,55 \%$ & 8,794 & & $-0,79$ & & \\
\hline Riscos & $32,83 \%$ & & & 0,004 & & \\
& $50,11 \%$ & 7,731 & & $-0,82$ & 0,55 & \\
& $44,57 \%$ & & & 0,002 & 0,002 & \\
\hline Contratos & 0 & & & & & \\
\hline Benchmarking & 0 & & & & & \\
\hline
\end{tabular}

A tabela 4.5 mostra o valor de $R^{2}$ e 0 valor de $R^{2}$ ajustado para as análises de regressão. Conforme mencionado na metodologgia, o percentual descrito no valor de $R^{2}$ significa o percentual de variação explicado pela regressão apresentada (MYERS; MONTGOMERY; VINING, 2001). Em outras palavras, a regressão vinculada ao aspecto de decisão custos explica cerca de $24 \%$ da variação encontrada na amostra, seguido por questões estratégicas com cerca de $37 \%$, perfil do profissional de $\mathrm{TI}$ com $40 \%$, aproximadamente e riscos com cerca de 50\%. Já os aspectos contratos e benchmarking não sofrem influencia, com representatividade estatística, dos fatores avaliados neste estudo. Os baixos percentuais mostram também a possível existência de outros fatores, ainda desconhecidos, que podem vir a contribuir para a determinação do nível de importância dos aspectos de decisão avaliados nesta pesquisa. 
No que diz respeito às colunas vinculadas as variáveis independentes, a tabela 4.5 apresenta o parâmetro matemático vinculado a cada regressor, ou co-variável, da equação de regressão associada aos aspectos de decisão estudados. Ela também apresenta o valor de $\rho$ que determina a evidência, ou não, de contribuição da covariável em relação à variável dependente em análise. $\mathrm{Na}$ tabela 4.5 , células sem nenhum dado (número) mostram que aquela co-variável não contribui para a explicação da variação buscada pela análise de regressão. Os regressores que contribuem para explicação da variação das variáveis dependentes, ou aspectos de decisão, são àquelas que possuem valor de $\rho$ inferior a 0,05 , ou $5 \%$.

Tabela 4.6 - Síntese da discussão dos resultados encontrados frente a literatura pesquisada.

\begin{tabular}{|c|c|c|c|}
\hline $\begin{array}{l}\text { Fator } \\
\text { externo }\end{array}$ & Aspecto de decisão & Resultado esperado & $\begin{array}{l}\text { Resultado } \\
\text { encontrado }\end{array}$ \\
\hline \multirow{6}{*}{ 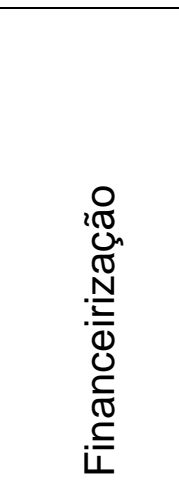 } & Questões estratégicas & $\begin{array}{l}\text { Correlação positiva } \\
\text { (BERGER, 2005; } \\
\text { STURGEON, 2002) }\end{array}$ & Sem influência \\
\hline & Custos & $\begin{array}{l}\text { Correlação positiva } \\
\text { (FLIGSTEIN, 2001) }\end{array}$ & Sem influência \\
\hline & Perfil do profissional & Sem influência & Sem influência \\
\hline & Riscos & $\begin{array}{l}\text { Correlação positiva } \\
\text { (RAPPAPORT, 2006) }\end{array}$ & Sem influência \\
\hline & Contratos & Sem influência & Sem influência \\
\hline & Benchmarking & Sem influência & Sem influência \\
\hline \multirow{6}{*}{$\begin{array}{l}F \\
\frac{\pi}{0} \\
\frac{0}{\mathbb{d}} \\
\frac{0}{\mathbb{D}} \\
0\end{array}$} & Questões estratégicas & $\begin{array}{l}\text { Correlação positiva (NOLAN; } \\
\text { McFARLAN, 2005) }\end{array}$ & Sem influência \\
\hline & Custos & Sem influência & Sem influência \\
\hline & Perfil do profissional & Sem influência & Sem influência \\
\hline & Riscos & $\begin{array}{l}\text { Correlação positiva (NOLAN; } \\
\text { McFARLAN, 2005) }\end{array}$ & $\begin{array}{l}\text { Correlação } \\
\text { positiva }\end{array}$ \\
\hline & Contratos & Sem influência & Sem influência \\
\hline & Benchmarking & Sem influência & Sem influência \\
\hline \multirow{6}{*}{ 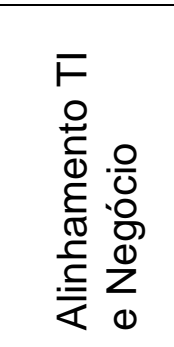 } & Questões estratégicas & $\begin{array}{l}\text { Correlação positiva } \\
\text { (LUFTMAN et al, 1999) }\end{array}$ & $\begin{array}{l}\text { Correlação } \\
\text { positiva }\end{array}$ \\
\hline & Custos & Sem influência & Sem influência \\
\hline & Perfil do profissional & Sem influência & Sem influência \\
\hline & Riscos & Sem influência & Sem influência \\
\hline & Contratos & Sem influência & Sem influência \\
\hline & Benchmarking & Sem influência & Sem influência \\
\hline
\end{tabular}

\section{continua}




\section{continuação}

\begin{tabular}{|c|c|c|c|}
\hline $\begin{array}{l}\text { Fator } \\
\text { externo }\end{array}$ & Aspecto de decisão & Resultado esperado & $\begin{array}{l}\text { Resultado } \\
\text { encontrado }\end{array}$ \\
\hline \multirow{6}{*}{ 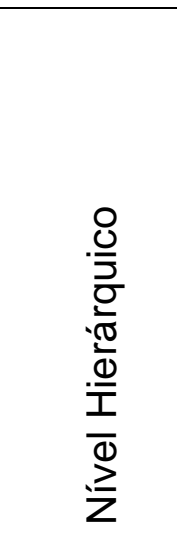 } & Questões estratégicas & $\begin{array}{l}\text { Correlação positiva (AVOLIO; } \\
\text { BASS, 1988) }\end{array}$ & $\begin{array}{l}\text { Correlação } \\
\text { negativa }\end{array}$ \\
\hline & Custos & Sem influência & $\begin{array}{l}\text { Correlação } \\
\text { negativa }\end{array}$ \\
\hline & Perfil do profissional & Sem influência & $\begin{array}{l}\text { Correlação } \\
\text { negativa }\end{array}$ \\
\hline & Riscos & $\begin{array}{l}\text { Correlação positiva (AVOLIO; } \\
\text { BASS, 1988) }\end{array}$ & $\begin{array}{l}\text { Correlação } \\
\text { negativa }\end{array}$ \\
\hline & Contratos & $\begin{array}{l}\text { Correlação positiva (AVOLIO; } \\
\text { BASS, 1988) }\end{array}$ & Sem influência \\
\hline & Benchmarking & Sem influência & Sem influência \\
\hline
\end{tabular}

Em função do exposto no parágrafo anterior, nota-se que a co-variável Financeirização não possui nenhuma influência na variação do nível de importância dos aspectos de decisão de terceirização de TI. Era esperado que a variável Financeirização trouxesse impacto ao aspecto questões estratégicas por conta dos movimentos estratégicos, como a concentração nas atividades centrais (BERGER, 2005; STURGEON, 2002), originados por este fenômeno. Outro impacto previsto dizia respeito a aspecto custos, por conta da característica intrínseca do movimento de Financeirização, ligado a influência do mundo financeiro na gestão das empresas (FLIGSTEIN, 2001). Finalmente, a questão da análise de riscos parecia também ser relevante, em função, principalmente, dos cuidados com a percepção de valor das empresas pelos acionistas (RAPPAPORT, 2006). Entretanto, como dito, não se verificou nenhuma dessas influências. Por outro lado, tal comportamento pode ser explicado levando em conta o contexto brasileiro. Isso porque tal movimento se encontra evoluído a tal ponto apenas nos Estados Unidos e na Europa (FROUD et al, 2006). Por esta razão, é possível que as empresas brasileiras não tenham se atentado as mudanças, em termos de valor para o acionista, que o movimento de terceirização pode trazer. De qualquer modo, dado que este estudo considera o contexto atual para a determinação do seu modelo de análise, os resultados encontrados mostram que não há evidências de que a Financeirização influencie no nível de importância dos aspectos de decisão de terceirização de funções de TI. 
A tabela 4.5 mostra que o Papel da TI dentro das empresas possui uma relação positiva com o nível de importância do aspecto de decisão riscos. Este relacionamento positivo entre o Papel da TI e Risco parece coerente uma vez que, à medida que a TI se torna mais estratégica para a empresa, maiores são os cuidados com os riscos de indisponibilidade das operações de TI. De acordo com Nolan e McFarlan (2005), a TI passa a ser estratégica para as empresas quando há perda de negócios pela indisponibilidade de sistemas e diminuição em tempo de resposta de aplicações. Tal característica operacional da função de $\mathrm{TI}$, para empresas onde a TI possui um papel mais estratégico, deve ser avaliada com critério em contratos de terceirização. É por este motivo, que se explica o crescente cuidado com a questão dos riscos para empresas em direção do quadrante estratégico, no grid McFarlan (1984). Por outro lado, Nolan e MacFarlan (2005) dizem que em empresas onde os sistemas de informação transformam significativamente os processos e serviços, ou que influenciam na distancia entre elas e os seus concorrentes, são aquelas em que a TI possui maior relevância estratégica estratégico. Por esta característica, esperava-se também um relacionamento positivo com 0 aspecto questões estratégicas, relacionamento este que não foi encontrado por esta amostra. Tal comportamento pode ser explicado pelo fato de que as empresas não consideram o processo de terceirização estratégica de Quinn e Hilmer (1994). Para tais empresas, terceirização deve ser feita para processos menos importantes, sendo os processos estratégicos executados internamente pela área de TI. Estudos futuros aprofundados nessa área podem trazer à luz um comportamento importante praticado pelas empresas brasileiras.

Quanto à influência do fator Alinhamento entre Negócio e TI, a tabela 4.5 mostra um relacionamento positivo entre este fator e o aspecto questões estratégicas. Em outras palavras, quanto maior o alinhamento entre o negócio e a TI, mais importante passa a ser a consideração do aspecto questões estratégicas. Usando os condicionadores de alinhamento entre a TI e o negócio de Luftman; Papp e Brier (1996), foi possível demonstrar tal relação positiva com o nível de importância do aspecto questões estratégicas. Por outro lado, a ausência de relação deste fator com os outros aspectos não demonstra ser um problema de pesquisa. Para empresas em que o alinhamento se faz presente, a determinação do nível de 
importância dos outros aspectos se dá pela estratégia de operação de cada empresa, não estando vinculado, portanto, com o alinhamento entre a TI e o negócio. Por outro lado, empresas sem o alinhamento definem o nível de importância dos aspectos de decisão levando em consideração outros fatores, diferentes do alinhamento entre a TI e o negócio.

A influência do fator Nível Hierárquico com o nível de importância dos aspectos de decisão foi deixada por última devido ao comportamento singular encontrado na pesquisa. Esperava-se crescimento no nível de importância de alguns aspectos (ex: questões estratégicas, contratos, riscos, entre outros) com o crescimento do nível hierárquico do profissional tomador de decisão. Profissionais em nível de direção tendem a serem mais transformacionais que outros (AVOLIO; BASS, 1988), por este motivo, deveriam considerar mais importantes os aspectos vinculados a esta característica transformacional. Foi encontrado comportamento oposto para todos os aspectos de decisão, à exceção de contratos e benchmarking, onde não foi encontrado relacionamento algum, dando indícios de que, ao menos no contexto brasileiro, as empresas não consideram terceirização de TI como uma ferramenta de transformação do negócio (VENKATRAMAN, 1997; DiROMUALDO; GURBAXANI, 1997) nem como estratégica (QUINN; HILMER, 1994). O decréscimo do nível de importância dos aspectos com o aumento do nível hierárquico mostra que a avaliação da decisão de terceirização de TI nas empresas brasileiras é feita pelos líderes transacionais. São estes profissionais que avaliam, de fato, nas empresas brasileiras, quando uma função de TI deve, ou não, ser terceirizada. Essa informação confirma o estudo de Dunham e Klafehn (1990), que demonstram que líderes transformacionais estão mais preocupados com a missão da empresa e com objetivos de longo prazo. Dada a característica de curto prazo de retorno que o processo de terceirização de TI possui (LACITY; HIRSCHHEIM, 1993; McFARLAN; NOLAN, 1995; LONSDALE; COX, 2000), parece então fazer sentido o comportamento encontrado. A tabela 4.6 sintetiza a discussão apresentada nos parágrafos anteriores.

Considerando as informações apresentadas e discutidas neste capítulo, pode-se então revisitar o modelo de pesquisa apresentado inicialmente e o redesenhar como apresentado na figura 4.9. Esse novo modelo apresenta informações novas no que 
diz respeito ao inter-relacionamento entre os aspectos de decisão de terceirização de TI. Mostra também a influências de alguns fatores em alguns dos aspectos de decisão considerados pelas empresas brasileiras, deixando também em aberto a possibilidade de influencia de outros fatores.
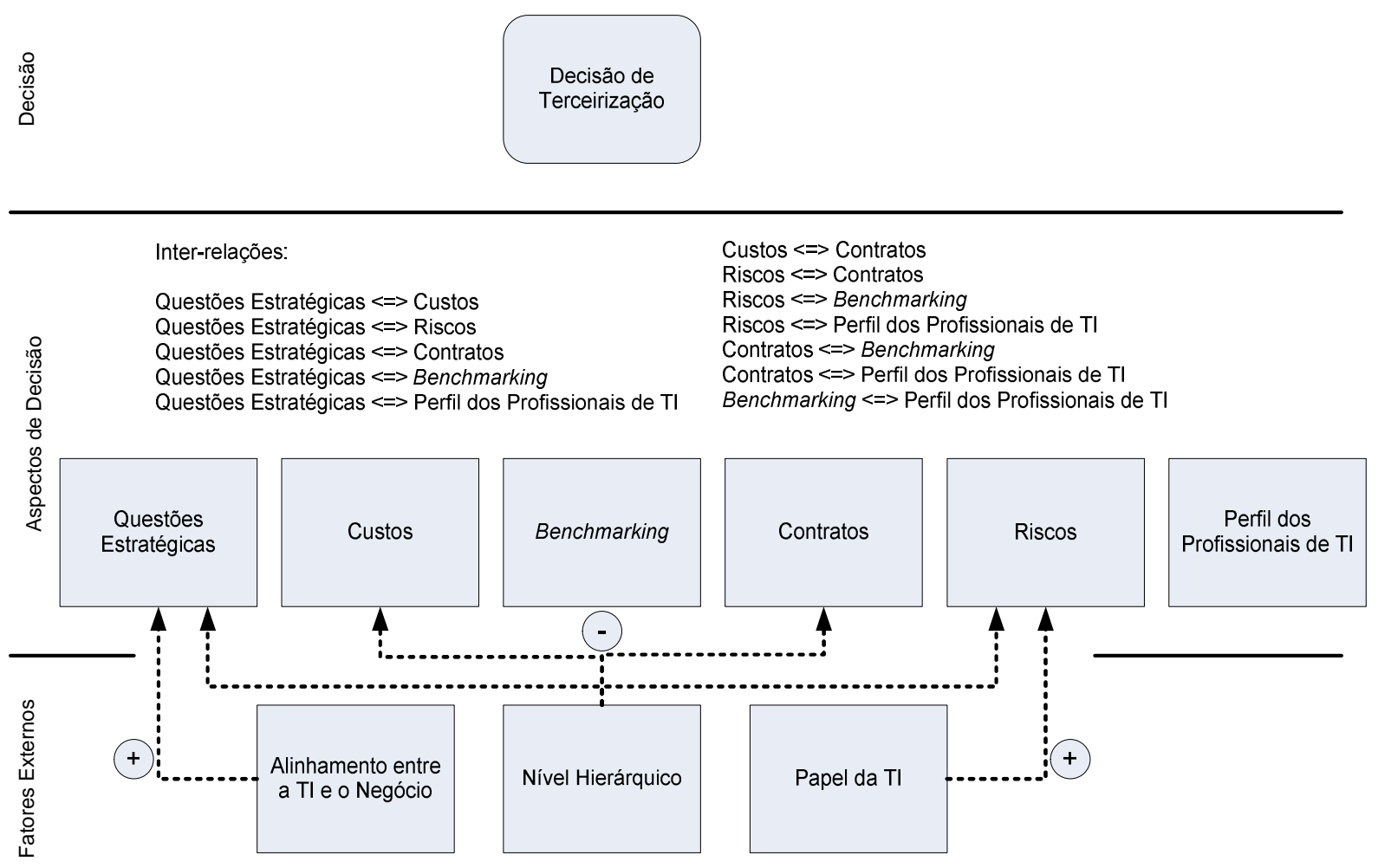

Figura 4.9 - Modelo de pesquisa revisitado, árvore de decisão hierárquica com os aspectos de decisão, suas inter-relações e fatores externos que influenciam no nível de importância dos aspectos. 


\section{CONCLUSÕES}

Este trabalho teve por objetivo entender questões que envolvem os aspectos considerados em decisões de terceirização de funções de $\mathrm{Tl}$ em empresas brasileiras. Utilizando-se de métodos de pesquisa distintos, respondeu a quatro questões de pesquisa, identificando um modelo final que permite um melhor entendimento sobre como a decisão de terceirização é tomada em empresas brasileiras. Tal modelo considera os aspectos de decisão usualmente considerados pelas empresas, o inter-relacionamento entre estes aspectos e fatores externos que contribuem para a definição do nível de importância de cada aspecto na decisão.

Para que o objetivo do trabalho fosse alcançado, fez-se necessário discutir os resultados encontrados nas diversas partes da pesquisa frente à literatura que trata do tema terceirização em TI. As pesquisas realizadas validaram resultados já apresentados por outros autores, solidificando o construto utilizado neste trabalho. Por outro lado, as pesquisas também encontraram resultados divergentes, trazendo a tona a necessidades de um melhor entendimento sobre os pontos em questão.

Do ponto de vista prático, o trabalho apresenta importante contribuição, pois ajuda a estruturar o processo de decisão de terceirização de funções de TI. Ao obter um melhor entendimento sobre como a dinâmica do processo de decisão de funções de TI ocorre em empresas brasileiras, gerou-se um modelo que permite estruturar este tipo de decisão. Portanto, as empresas brasileiras podem então se utilizar do modelo a fim de verificar se todos os aspectos da decisão estão sendo avaliados, diminuindo os riscos do processo a aumentando os benefícios.

Cabe ressaltar as limitações de pesquisa deste trabalho. Embora se tenha buscado utilizar de métodos consistentes para o levantamento e análise dos dados, foram encontrados obstáculos que colocam em questão os resultados encontrados. A simulação do primeiro modelo frente ao contexto de uma única empresa, as limitações estatísticas das amostras utilizadas e os baixos índices de variação 
explicados pelos modelos de regressão são apenas alguns exemplos. Portanto, este trabalho não pretende apresentar um modelo definitivo, tão pouco encerrar a discussão sobre o tema em questão, dado as sugestões de estudos futuros apresentadas anteriormente. De qualquer maneira, considera-se que os resultados apresentados demonstram evidências suficientes de que o objetivo da pesquisa foi alcançado e as perguntas de pesquisa devidamente respondidas, para, pelo menos, parte da população.

Finalmente, em relação a estudos futuros, sugere-se o desenvolvimento de três linhas. A primeira diz respeito a continuidade desta pesquisa, validando o modelo proposto e a entendendo melhor as divergências encontradas. Estes desenvolvimentos parecem ser relevantes, diante da importância do tema nos dias atuais. A segunda gira ao entorno da necessidade de verificação dos aspectos de decisão e da influência de novos fatores externos. Tais elementos do modelo podem ser dinâmicos e sofrerem alterações ao longo do tempo. Um exemplo de tal dinamismo é a colocação da gestão do conhecimento como fator relevante em decisões estratégicas da natureza discutida em terceirizações. Outro exemplo diz respeito ao cenário econômico global nos dias atuais, trazendo à tona a questão da financeirização. Por último, a inversão da lógica analisada, ou seja, verificar como tais aspectos de decisão de terceirização de funções de TI são trabalhados pelos fornecedores a fim de entregar um serviço mais aderente às necessidades dos seus clientes. 


\section{REFERÊNCIAS BIBLIOGRÁFICAS}

AFUAH, A. How much do your competitors' capabilities matter in the face of technological change? Strategic Management Journal. v. 21, n. 03, p. 397-404, 2000.

AHUJA, G. The duality of collaboration: inducements and opportunities in the formation of interfirm linkages. Strategic Management Journal. v. 21, n. 03, p. 317343, 2000.

ARMSTRONG, P. The costs of activity-based management. Accounting, Organizations and Society. v. 27, n. 01, p. 99-120, 2002.

ARNETT, K.; JONES, M. Firms that choose outsourcing: A profile. Information \& Management. v. 26, n. 04, p. 179-188, 1994.

AUBERT, B.; RIVARD, S.; PATRY, M. A transaction cost approach to outsourcing behavior: some empirical evidence. Information \& Management. v. 30, n. 02, p. 5164, 1996.

AUBERT, B.; RIVARD, S.; PATRY, M. A transaction cost model for IT outsourcing. Information \& Management. v. 41, n. 07, p. 921-932, 2004.

AVOLIO, B.J.; BASS, B.M. Transformational leadership, charisma, and beyond. In: HUNT, J.G.; BAGLIA, B.R.; DACHLER, H.P.; SCRIESCHEIM, C.A. Emerging Leadership, 1. ed. Lexington: Lexington Books, 1988.

BARTHELEMY, J. The hidden costs of IT outsourcing. Sloan Management Review. v. 42, n. 03, p. 60-69, 2001.

BASS, B.M.; WALDMAN, D.A.; AVOLIO, B.J.; BEBB, M. Transformational leadership and the falling dominoes effect. Group and Organisation Studies. v. 12, n. 01, p. 73-87, 1987.

BERGER, S. How We Compete: What Companies Around the World Are Doing to Make It in Today's Global Economy. 2. ed. Doubleday, 2005. 
BERNSTORFF, V.H. A Gestão da Tecnologia da Informação em Estruturas Terceirizadas: Aspectos de controle organizacional. Dissertação (Mestrado). Programa de Pós-Graduação em Administração da Universidade Federal do Paraná, Curitiba, 2000.

BERTRAND, J.W.M.; FRANSOO, J.C. Operations management research methodologies using quantitative modeling. International Journal of Operations \& Production Management. v. 22, n. 02, p. 241-264, 2002.

BLACK, A.; WRIGHT, P.; BACHMAN, J. E.; DAVIES, J. In Search of Shareholder Value: Managing the Drivers of Performance. 1. ed. London: FT Pitman Publishing, 1998.

BRITO, J. Cooperação interindustrial e redes de empresas. In: KUPFER, D.; HASENCLEVER, L. Economia industrial: Fundamentos teóricos e práticos no Brasil. 2. ed. Rio de Janeiro: Campus, 2002.

BRODBECK, A. Alinhamento Estratégico entre Planos de Negócio e de Tecnologia de Informação: um modelo operacional para a implementação. Tese (Doutorado). Programa de Pós-Graduação em Administração da Universidade Federal do Rio Grande do Sul, Porto Alegre, 2001.

BRUHN, P. Alinhamento Estratégico de TI: Importância, Modelos e Relações. In: CONGRESSO ANUAL DE TECNOLOGIA DA INFORMAÇÃO. 2004, São Paulo. Anais... São Paulo, Fundação Getúlio Vargas, 2004.

BULLEN, C.V.; ABRAHAM, T.; GALLAGHER, K.; KAISER, K.M.; SIMON, J. Changing IT skills: The impact of sourcing strategies on in-house capability requirements. Journal of Eletronic Commerce in Organizations. v. 05, n. 02, p. 24-46, 2007.

CARR, N. It Doesn't Matter. Harvard Business Review. v.81, n.5, p. 41-49, 2003.

CARSON, D.; COVIELLO, N. Qualitative research issues at the marketing / entrepreneurship interface. Marketing Intelligence \& Planning. vol. 14, n. 06, p. 51$58,1996$.

CHOO, C.W. Knowing organizations. Oxford: Oxford University Press, 1998.

CROTTY, J. The neoliberal paradox: the impact of destructive product market competition and 'modern' financial markets on nonfinancial corporation performance 
in the neoliberal era. In: Epstein, G A. Financialization and the World Economy. 1. ed. Edward Elgar Pub, 2006.

CUNHA, M.J. Desafios Percebidos pelos Terceirizados na Prestação de Serviços em Tecnologia da Informação: $O$ caso Alfa-BH. Dissertação (Mestrado profissionalizante). Programa de Pós-Graduação em Administração das Faculdades Integradas de Pedro Leopoldo, Belo Horizonte, 2006.

DIAS FERREIRA, A.M.; LAURINDO, F.J.B.; SHIMIZU, T. Decisão de terceirização de funções da TI com o uso do método ANP: proposta de modelo, simulação e estudo de casos. In: 3o Simpósio Brasileiro de Sistemas de Informação, 2006, Curitiba. Anais do 3 o Simpósio Brasileiro de Sistemas de Informação. Porto Alegre: SBC, 2006.

DiROMUALDO, A.; GURBAXANI, V. Strategic intent for IT outsourcing. Sloan Management Review. v. 39, n. 04, p. 67-80, 1998.

DUNHAM, J.; KLAFEHN, K.A. Transformational leadership and the nurse executive. Journal of Nursing Administration. v. 20, n. 04, p. 28-34, 1990.

EARL, M. The risks of outsourcing IT. Sloan Management Review. v. 37, n. 03, p. 26-32, 1996.

ENRIGHT, M.J. Regional clusters and firms strategy. Paper prepared for the Prince Bertil Symposium. Boston: Harvard Business School, 1994.

FARBEY, B.; LAND, F.; TARGETT, D. A taxonomy of information systems applications: The benefits evaluation ladder. European Journal of Information Systems. v.4, n.1, p. 41-50, 1995.

FARIA, I.P. Gestão dos Recursos de Infra-Estrutura de Tecnologia da Informação por Meio do Outsourcing. Dissertação (Mestrado). Programa de Pós-Graduação em Engenharia de Produção da Universidade Paulista, São Paulo, 2004.

FARINA, E.M.M.Q; de AZEVEDO, P.F.; SAES, M.S.M. Competitividade: mercado, estado e organizações. 1. ed. São Paulo: Singular, 1997.

FERREIRA, L.B. Terceirização em TI sob os Aspectos de Estratégia, Tomada de Decisão e Análise de Investimentos - Estudo de Múltiplos Casos em Três Organizações Franqueadas da Coca-Cola do Brasil. Dissertação (Mestrado). 
Programa de Pós-Graduação em Engenharia de Produção da Universidade Federal do Rio Grande do Norte, Natal, 2005.

FISCINA, H.M. A Organização de Negócios por Contrato de Terceirização: Uma Aplicação à Indústria de Tecnologia de Informação no Brasil. Tese (Doutorado). Programa de Pós-Graduação em Administração de Empresas da Fundação Getúlio Vargas, São Paulo, 2003.

FLIGSTEIN, N. The Architecture of Markets. 1. ed. New Jersey: Princeton University Press, 2001.

FORMAN, E.H.; SELLY, M.A. Decision by objectives - How to convince other that you are right. 1 ed. Singapore: World Scientific Publishing Company, 2002.

FORZA, C. Survey research in operations management: a process-based perspective. International Journal of Operations \& Production Management. v. 22, n. 02, p. 152-194, 2002.

FREUND, J. E.; SIMON, G. A. Estatística Aplicada. 9. ed. Porto Alegre: Bookman, 2000.

FROUD, J.; SUKHDEV, J.; LEAVER, A.; WILLIAMS, K. Financialization and Strategy: Narrative and Numbers. 1. ed. Routledge, 2006.

GONÇALVES, A.P. A influência da estratégia de terceirização de sistemas de informação do alinhamento entre estratégia de negócios e de TI. Dissertação (Mestrado profissionalizante). Programa de Pós-Graduação em Administração do Centro Universitário Nove de Julho, São Paulo, 2006.

GRANDORI, A.; SODA, G. Inter-firm networks: Antecedents, mechanisms and forms. Organizational Studies. v. 16, n. 02, p. 183-214, 1995.

HAIR, J. F.; TATHAM, R. L.; ANDERSON, R. E.; BLACK, W. Multivariate Data Analysis. 5. ed. New York: Prentice Hall, 1998.

HAMEL, G.; PRAHALAD, C. The Core Competencies of the Corporation. Harvard Business Review. v.68, n.3, p. 79-90, 1990. 
HENDERSON, J.; VENKATRAMAN, N. Strategic Alignment: Levering Information Technology for Transforming Organizations. IBM Systems Journal. v.32, n.1, p. 416, 1993

HUBER, R. How Continental Bank outsourced its "Crown Jewels". Harvard Business Review. v. 72, n. 01, p. 121-129, 1993.

HUMPHREY, J.; SCHMITZ, H. Governance and upgrading in global value chains. A Backgroung Paper for the Bellagio Value Chain Workshop. Brighton: Institute of Development Studies - University of Sussex, 2000.

HUMPHREY, J.; SCHMITZ, H. Trust and inter-firm relations in developing and transition economies. The Journal of Development Studies. v. 34, n. 4, p. 32-61, 1998.

HURLEY, M.; SCHAUMANN, F. KPMG survey: the IT outsourcing decision. Information Management \& Computer Security. v. 05, n. 04, p. 126-132, 1997.

IGLIORI, D.C. Economia dos clusters industriais e desenvolvimento. 1. ed. São Paulo: Iglu, 2001.

JÚNIOR, M.M. Uma Ferramenta de Apoio à Decisão na Escolha de Fornecedores de Tecnologia de Informação Baseado na Lógica Paraconsistente Anotada. Dissertação (Mestrado). Programa de Pós-Graduação em Engenharia de Produção da Universidade Paulista, São Paulo, 2006.

KHANNA, T.; GULATI, R.; NOHRIA, N. The dynamics of learning alliances: competition, cooperation, and relative scope. Strategic Management Journal. v. 19, n. 03, p. 193-210, 1998.

KIPPENBERGER, T. Some hidden costs if outsourcing. The Antidote. v. 02, n. 06, p. 22-23, 1997.

LACITY, M.; HIRSCHHEIM, R. The information systems outsourcing bandwagon. Sloan Management Review. v. 35, n. 01, p. 73-86, 1993.

LACITY, M.; WILLCOCKS, P.; FEENY, D. IT outsourcing: Maximize flexibility and control. Harvard Management Review. v. 74, n. 03, p. 84-93, 1995. 
LAURINDO, F.J.B. Decisões em problemas da Tecnologia da Informação. In: SHIMIZU, T. Decisão nas organizações. 2 ed. São Paulo: Atlas, 2006.

LAURINDO, F.J.B. Tecnologia da Informação: Eficácia nas Organizações. 1. ed. São Paulo: Futura, 2002.

LAURINDO, F.J.B.; DIAS FERREIRA, A.M. Estudos fármaco-econômicos e sua rede de utilização no Brasil: estudo de casos. In: XXIV Simpósio de Gestão da Inovação Tecnológica, 2006, Gramado. Anais do XXIV Simpósio de Gestão da Inovação Tecnológica. Rio de Janeiro: ANPAD, 2006.

LAVE, C.A.; MARCH, J.G. An introduction to models in the social sciences. 1. ed. New York: Harper \& Row Publishers, 1975.

LEDERER, A.; MENDELOW, A. Issues in Information Sysntems Plannig. Information \& Management. v.10, n.5, p. 245-254. 1986.

LEVINA, N.; ROSS, J.W. From the vendor's prespective: Exploring the value proposition in information technology outsourcing. MIS Quarterly. v. 27, n. 03, p. 331-364, 2003.

LIRA, P.C. Estratégias de Outsourcing para Áreas de TI: Um Estudo de Caso na Gedas/Volkswagen. Dissertação (Mestrado). Programa de Pós-Graduação em Administração da Pontifícia Universidade Católica de São Paulo, São Paulo, 2003.

LONSDALE, C.; COX, A. The historical development of outsourcing: the latest fad? Industrial Management \& Data Systems. v. 100, n. 09, p. 444-450, 2000.

LOOF, L. Information systems outsourcing decision making: A managerial approach. 1. ed. New York: Idea Group Publishing, 1997.

LOWE, K.B.; KROECK, K.G.; SIVASUBRAMANIAM, N. Effectiveness correlates of transformational and transactional leadership: a meta-analytic review of the MLQ literature. Leadership Quarterly. v. 07, n. 03, p. 385-425, 1996.

LUFTMAN, J. Assessing strategic alignment maturity. In: LUFTMAN, J. Competing in the information age. 2. ed. Oxford: Oxford University Press, 2003. 
LUFTMAN, J.; PAPP, R.; BRIER, T. Enablers and inhibitors of business-IT alignment. Communications of the Association for Information Systems. v. 11, n. 1, p., 1996.

McFARLAN, F. Information Technology Changes The Way You Compete. Harvard Business Review. v. 62, n.3, p. 98-103, 1984.

McFARLAN, F.; McKENNEY, J.; PYBURN, P. The Information Archipelago - Plotting a Course. Harvard Business Review. v. 61, n.1, p. 145-156, 1983.

McFARLAN, F.W.; NOLAN, R.L. How to manage an IT outsourcing alliance. Sloan Management Review. v. 36, n. 02, p. 09-23, 1995.

MclVOR, R. A practical framework for understanding the outsourcing process. Supply Chain Management. v., 05, n. 01, p. 22-36, 2000.

MEADE, L.M.; PRESLEY, A. R\&D Project selection using the Analytic Network Process. IEEE Transactions on Engineering Management. v. 49, n. 01, February, 2002.

MITROFF, I.I.; BETZ, F.; PONDY, L.R.; SAGASTI, F. On managing science in the systems age: two schemas for the study of science as a whole systems phenomenon. Interfaces. v. 04, n. 03, p. 46-58, 1974.

MOURA, M.G.T.F.F. Terceirização de Serviços de Tecnologia de Informação em Bancos. Dissertação (Mestrado). Programa de Pós-Graduação em Administração da Universidade Federal do Rio de Janeiro, Rio de Janeiro, 1996.

MUNIZ, G.P. Mecanismos de Governança na Terceirização dos Serviços de Tecnologia da Informação: uma análise em empresas do Estado do ES. Dissertação (Mestrado profissionalizante). Programa de Pós-Graduação em Ciências Contábeis da Fundação Instituto Capixaba de Pesquisa em Contabilidade, Economia e Finanças, Vitória, 2006.

MYERS, R.H.; MONTGOMERY, D.C.; VINING, G.G. Generalized Linear Models: With Applications in Engineering and the Sciences. 1. ed. New York: John Wiley \& Sons, 2001.

NADKARNI, S.; SHENOY, P.P. A casual mapping approach to constructing Bayesian networks. Decision Support Systems. v. 38, n. 02, p. 259-281, November, 2004. 
NEUMANN, S.; AHITUV, N.; ZVIRAN, M. A Mesure for Determinig the Strategic Relevance of IS to the Organization. Information \& Management. v. 22, n.5, p. 281299, 1992.

NOLAN, R. Managing the Crises in Data Processing. Harvard Business Review. v. 57, n. 2, p. 115-126, 1979.

OLIVEIRA, D.N.P. Estratégias de Terceirização dos Serviços da Tecnologia de Informação em Instituições Bancárias do Mercado Brasileiro. Dissertação (Mestrado profissionalizante). Programa de Pós-Graduação em Controladoria da Universidade Federal do Ceará, Fortaleza, 2005

OSHAGBEMI, T.; GILL, R. Differences in leadership styles and behaviour across hierarchical levels in UK organizations. Leadership \& Organization Development Journal. v. 25, n. 01, p. 93-106, 2004.

PAISITTANAND, S.; OLSON, D.L. A simulation study of IT outsourcing in the credit card business. European Journal of Operational Research. v. 175, n. 2, p.12481261, 2006.

PAPP, R.; LUFTMAN, J. Business and I/T Strategic Alignment: New perspective and assessments. In: PROCEEDINGS OF THE ASSOCIATION FOR INFORMATION SYSTEMS, Inaugural Americas Conference on Information Systems, 1995.

PERKS, H.; JEFFERY, R. Global network configuration for innovation: a study of international fibre innovation. R\&D Management. v. 36, n. 01, p. 67-83, 2006.

PORTAL EXAME. São Paulo: Editora Abril, 2005. Mercado global para serviços de TI muda e favorece Brasil. Disponível em: $<$ http://portalexame.abril.com.br/tecnologia/n0079614.html?printable=true>. Acesso em: 01 Jan. 2007.

PORTAL EXAME. São Paulo: Editora Abril, 2005b. Marketing das competências e fluência em inglês favorecem concorrentes do Brasil. Disponível em: $<$ http://portalexame.abril.com.br/tecnologia/m0079211.html?printable=true $>$. Acesso em: 01 Jan. 2007.

PORTAL EXAME. São Paulo: Editora Abril, 2006. Terceirização cresce 127\% em dez anos. Disponível em: <http://portalexame.abril.com.br/degustacao/secure/degustacao.do?COD_SITE=35\& COD_RECURSO=211\&U>. Acesso em: 01 Jan. 2007. 
PORTER, M.; MILLAR, V. How Information Gives You Competitive Advantage. Harvard Business Review. v. 63, n. 4, p. 149-160, 1985.

PORTER, M.E. Vantagem Competitiva das Nações. 8. ed. São Paulo: Campus, 2001.

PRADO, E.P.V. Tecnologia de Informação e Sistemas: Uma Avaliação da Terceirização de Serviços em Organizações do Setor Privado. Tese (Doutorado). Programa de Pós-Graduação em Administração da Universidade de São Paulo, São Paulo, 2005.

PRADO, E.P.V. Terceirização da Tecnologia de Informação: Uma Avaliação dos Fatores que Motivam sua Adoção em Empresas do Setor Industrial de São Paulo. Dissertação (Mestrado). Programa de Pós-Graduação em Administração da Universidade de São Paulo, São Paulo, 2000.

QUINN, J.; HILMER, G. Strategic outsourcing. Sloan Management Review. v. 35, n. 04, p. 43-55, 1994.

RAPPAPORT, A. Ten Ways to Create Shareholder Value. Harvard Business Review. v. 84, n. 09, p. 36-47, 2006.

REICH, B.; BENBASAT, I. Measuring the linkage between business and information technology objectives. MIS Quarterly. v. , n. , p. 55-81, 1996.

ROCKART, J. Chief Executives Define Their Own Data Needs. Harvard Business Review. v. 57, n. 2, p.81-92, 1979.

ROCKART, J.; MORTON, M. Implications of Changes in Information Technology for Corporate Strategy. Interfaces. v. 14, n. 01, p. 84-95, 1984.

SANTOS, C.A.P.N. Processo de Terceirização do Desenvolvimento de Sistemas de Informação. Dissertação (Mestrado). Programa de Pós-Graduação em Administração da Universidade de Fortaleza, Fortaleza, 2000.

SCHMITZ, H. Small firms and flexible specialization in LCDs. Brighton: Institute of Development Studies - University of Sussex, 1989.

SHIMIZU, T. Decisão nas organizações. 2 ed. São Paulo: Atlas, 2006. 
STURGEON, T.J. Modular production networks: a new American model of industrial organization. Industrial and Corporate Change. v. 11, n. 03, p. 451-496, 2002.

TAFTI, M. Risks factors associated with offshore IT outsourcing. Information Management \& Data Systems. v. 105, n. 05, p. 549-560, 2005.

TAYLOR, H. Outsourced IT Projects from the Vendor Perspective: Different Goals, Different Risks. Journal of Global Management. v. 15, n. 02, p. 01-27, 2007.

TEO, T.; KING, W. Integration Between Business Planning and Information Systems Planning: An Evolutionary-Contingency Perspective. Journal of Management Information Systems. v.14, n.1, p. 185-214, 1997.

TRIOLA, M. F. Introdução à Estatística. 7. ed. Rio de Janeiro: LTC, 1999.

TURBAN, E.; ARONSON, J.E. Decision support systems and intelligent systems. 5 ed. Englewood Cliffs: Prentice Hall, 1998.

USSEM, M. Investor Capitalism: How Money Managers Are Changing the Face of Corporate America. 1. ed. New York: Basic Books, 1996.

VASSILIADIS, B.; STEFANI, A.; TSAKNAKIS, J.; TSAKALIDIS, A. From application service provision to service-oriented computing: A study of the IT outsourcing evolution. Telematics and Information. v. 23, n. 04, p. 271-293, 2006.

VOSS, C.; TSIKRIKTSIS, N.; FROHLICH, M. Case research in operations management. International Journal of Operations \& Productions Management. v. 22, n. 2, p. 195-219, 2002.

VENKATRAMAN, N. Beyond outsourcing: managing IT resources as a value center. Sloan Management Review. v. 38, n. 03, p. 51-63, 1997.

WAINSTOK, R. A. Utilização Estratégica da Tecnologia de Informação em Bancos Múltiplos: Um Estudo no Rio de Janeiro e São Paulo. Dissertação (Mestrado). Programa de Pós-Graduação em Administração da Universidade Federal do Rio de Janeiro, Rio de Janeiro, 1995.

WALTON, R. Tecnologia da Informação: O uso de TI pelas empresas que obtêm vantagem competitiva. 1. ed. São Paulo: Atlas, 1993. 
WHITTEN, D.; LEIDNER, D. Bringing IT back: An analysis of the decision to backsource or switch vendors. Decision Sciences. v. 37, n. 04, p. 605-621, 2006.

WILLCOCKS, L.; LESTER, S. In search of information technology productivity: assessment issues. Journal of the Operational Research Society. v.48, n.11, p. 1082-1094, 1997.

WILLIANSON, O.E. Transaction cost economics: the governance of contractual relations. Journal of Law and Economics. v. 22, p. 233-262, 1979.

WOMACK, J. P.; JONES, D. T. A Mentalidade Enxuta Nas Empresas: Elimine o Desperdício e Crie Riqueza. 4. ed. Rio de Janeiro: Campus, 1998.

YIN, R. Estudo de caso: planejamento e métodos. 3 ed. Porto Alegre: Bookman, 2005. 


\section{ANEXO A - ROTEIRO USADO PARA RESPONDER À QUESTÃO DE PESQUISA Q2}

Como você considera a contribuição da TI para o negócio da sua empresa em termos de impacto presente e impacto futuro? A TI pode criar barreiras de entrada? A TI pode mudar a base da competição? A TI pode alterar o relacionamento com fornecedores? A TI pode alterar o relacionamento com clientes? A TI pode gerar possibilidades de novos produtos?

Como você considera o impacto dos sistemas de informação no negócio da empresa em caso de parada? Um elevado tempo de resposta das aplicações de $\mathrm{TI}$ comprometeriam o negócio da sua empresa? Seus sistemas internos possuem ligações com seus fornecedores ou seus clientes? Caso existam essas ligações, a indisponibilidade delas traz impacto para o seu negócio? Em caso de parada das aplicações, elas podem ser trazidas para um sistema manual rapidamente? Seus sistemas de informação trazem diferenciação estratégica e reduções grandes de custo? Qual o orçamento da TI em relação ao faturamento da empresa (investimento e custo)?

As práticas gerenciais adotadas pela área de $\mathrm{TI}$ são atualizadas, em que grau? Vocês possuem uma massa significativa de serviços de TI, em que grau? Em que grau é o nível de terceirização dos componentes de vocês (hardware, software, pessoas, procedimentos e dados)? Em que grau os sistemas de informações de vocês são terceirizados (sistemas de suporte secundários, sistemas de suporte primários ou sistemas primários)? Em que grau, as atividades de vocês são terceirizadas (operação, manutenção, implementação, desenvolvimento e planejamento)?

Descreva em detalhes os três casos terceirizados que serão utilizados neste estudo. Trata-se de uma terceirização de infra-estrutura, de software ou de ambos? Qual o 
custo de investimento deste projeto de terceirização? Qual o custo mensal desta função terceirizada? Como foi o processo de decisão para a resolução deste problema? O que os motivou a tomar essa decisão de terceirização? Quantas pessoas estão envolvidas na operação desta função em sua empresa? Essa função terceirizada possui impacto significativo nos negócios da sua empresa?

Do ponto de vista do alinhamento entre a TI e o negócio, onde se originou a busca pelos serviços terceirizados, na estratégia do negócio, na de $\mathrm{Tl}$, nos processos organizacionais ou nos processos de TI? Você considera que o principal beneficiário foi a estratégia do negócio, ou seja, os serviços buscados no mercado visavam, em última instância a estratégia do negócio? Em caso negativo, visavam a infraestrutura e os processos organizacionais?

Classificar suas operações terceirizadas de acordo com o impacto das aplicações terceirizadas para as operações e o impacto estratégico das aplicações da TI (verificar cada um dos três casos estudados)

Considerando a tipologia apresentada para você, pontue usando a escala: sem importância, pouco importante, importante, muito importante e essencial, os aspectos descritos para cada um dos projetos estudados.

Projeto 1:

\begin{tabular}{|l|l|l|l|l|l|}
\hline & $\begin{array}{l}\text { Sem } \\
\text { importância }\end{array}$ & $\begin{array}{l}\text { Pouco } \\
\text { importante }\end{array}$ & Importante & $\begin{array}{l}\text { Muito } \\
\text { importante }\end{array}$ & Essencial \\
\hline Estratégico & & & & & \\
\hline Custo & & & & & \\
\hline Risco & & & & & \\
\hline Contratos & & & & & \\
\hline Benchmarking & & & & & \\
\hline $\begin{array}{l}\text { Perfil do } \\
\text { profissional de TI }\end{array}$ & & & & & \\
\hline
\end{tabular}

Projeto 2:

\begin{tabular}{|l|l|l|l|l|l|}
\hline & $\begin{array}{l}\text { Sem } \\
\text { importância }\end{array}$ & $\begin{array}{l}\text { Pouco } \\
\text { importante }\end{array}$ & Importante & $\begin{array}{l}\text { Muito } \\
\text { importante }\end{array}$ & Essencial \\
\hline Estratégico & & & & & \\
\hline Custo & & & & & \\
\hline Risco & & & & & \\
\hline
\end{tabular}




\begin{tabular}{|l|l|l|l|l|l|}
\hline Contratos & & & & & \\
\hline Benchmarking & & & & & \\
\hline $\begin{array}{l}\text { Perfil do } \\
\text { profissional de TI }\end{array}$ & & & & & \\
\hline
\end{tabular}

Projeto 3:

\begin{tabular}{|l|l|l|l|l|l|}
\hline & $\begin{array}{l}\text { Sem } \\
\text { importância }\end{array}$ & $\begin{array}{l}\text { Pouco } \\
\text { importante }\end{array}$ & Importante & $\begin{array}{l}\text { Muito } \\
\text { importante }\end{array}$ & Essencial \\
\hline Estratégico & & & & & \\
\hline Custo & & & & & \\
\hline Risco & & & & & \\
\hline Contratos & & & & & \\
\hline Benchmarking & & & & & \\
\hline $\begin{array}{l}\text { Perfil do } \\
\text { profissional de TI }\end{array}$ & & & & & \\
\hline
\end{tabular}

Iniciar a simulação com o ANP. 


\section{ANEXO B - FORMULÁRIO USADO PARA RESPONDER À QUESTÃO DE PESQUISA Q3}

I - Identificação do respondente do questionário:

Nome:

Telefone para contato:

E-mail:

Cargo atual:

II - Informações sobre a empresa:

Nome:

Faturamento aproximado anual (opcional):

Número total de funcionários:

Possui capital aberto (ações em bolsa)? Sim ( ) Não ( )

III - Perguntas sobre decisão de terceirização:

Que tipo de terceirização é realizado na empresa em que você trabalha? Marque as opções que se enquadram na sua resposta (marque mais de uma, se necessário):

\begin{tabular}{|c|c|}
\hline De sistema de informação & $\begin{array}{l}\text { Primários ( ) - De suporte ( ) - De suporte } \\
\text { secundário ( ) }\end{array}$ \\
\hline De componentes & Hardware () - Software ( ) - Pessoas ( ) \\
\hline De atividades & $\begin{array}{l}\text { Planejamento ( ) - Desenvolvimento ( ) - } \\
\text { Implementação ( ) - Manutenção ( ) - } \\
\text { Operação ( ) }\end{array}$ \\
\hline
\end{tabular}


Considere o entendimento sobre os aspectos descritos na tabela abaixo para responder as perguntas logo a seguir:

\begin{tabular}{|c|c|}
\hline Aspecto & Detalhamento \\
\hline $\begin{array}{l}\text { Questões } \\
\text { estratégicas }\end{array}$ & $\begin{array}{l}\text { Este aspecto volta-se, em grande parte, para os benefícios } \\
\text { incorridos com a formação de alianças estratégicas entre o cliente e } \\
\text { o fornecedor da terceirização. Alguns exemplos destes benefícios } \\
\text { são: utilização de inovações e capacidades profissionais dos } \\
\text { fornecedores; possibilidade de rápidas mudanças de mercado e de } \\
\text { cenários tecnológicos, diminuindo riscos, ciclo de vida de produtos } \\
\text { e investimentos, além de criar um mecanismo de atendimento } \\
\text { imediato às necessidades dos clientes. }\end{array}$ \\
\hline Custos & $\begin{array}{l}\text { Esta questão aborda não somente os detalhes relacionados aos } \\
\text { custos das opções de terceirizar ou fazer internamente. Ele deve } \\
\text { cobrir aspectos relacionais aos chamados custos "escondidos", ou } \\
\text { seja, os custos incorridos com a administração do contrato (em } \\
\text { caso de terceirização) de eventuais mudanças de fornecedores, de } \\
\text { possíveis re-internalizações das funções terceirizadas, caso haja } \\
\text { descontentamento com o serviço prestado pelo fornecedor, etc. } \\
\text { Além disso, o conhecimento e aplicação dos conceitos de custos } \\
\text { transacionais são de grande relevância. }\end{array}$ \\
\hline $\begin{array}{l}\text { Perfil do } \\
\text { profissional de } \\
\text { TI }\end{array}$ & $\begin{array}{l}\text { Optar pela terceirização implica, necessariamente, em mudanças } \\
\text { no estilo de gestão da função da TI recém terceirizada. Antes da } \\
\text { terceirização, as pessoas envolvidas na operação da área } \\
\text { precisavam ter habilidades técnicas de forma a garantir a operação } \\
\text { do serviço. Após a terceirização, as habilidades das pessoas } \\
\text { envolvidas mudam de técnica para administrativa. Em outras } \\
\text { palavras, a área de TI do cliente deixa de ser operadora do serviço } \\
\text { para ser administradora. Além disso, a questão da terceirização } \\
\text { pode trazer impactos do ponto de vista estratégico e de novos } \\
\text { negócios. }\end{array}$ \\
\hline Riscos & $\begin{array}{l}\text { A questão dos riscos da terceirização das funções da TI é } \\
\text { amplamente discutida na literatura, além de possuir um } \\
\text { relacionamento direto com os outros aspectos discutidos nesta } \\
\text { tabela. Por exemplo, os custos escondidos de um processo de } \\
\text { terceirização possuem um relacionamento direto com os riscos de } \\
\text { insucesso, ou seja, um nível maior de custos não detectados pode } \\
\text { caracterizar um retorno financeiro menor que o esperado. Da } \\
\text { mesma forma, a perda de privacidade e de segurança das } \\
\text { informações, além da perda de experiência técnica da TI, parece } \\
\text { estar bastante relacionada ao aspecto de questões estratégicas. } \\
\text { Além disso, os riscos podem estar ligados ao próprio processo } \\
\text { decisório e ao escopo da terceirização. }\end{array}$ \\
\hline
\end{tabular}




\begin{tabular}{|l|l|}
\hline Contratos & $\begin{array}{l}\text { A questão da elaboração dos contratos de terceirização deve } \\
\text { discutir os pontos que viabilizem um contrato duradouro entre as } \\
\text { partes. Em outras palavras o contrato deve: garantir o } \\
\text { estabelecimento de uma aliança estratégica entre as partes; } \\
\text { permitir que os clientes tenham acessos ao conhecimento técnico } \\
\text { do fornecedor; trazer redução de custos para o cliente sempre que } \\
\text { houver mudança de base tecnológica (ou pelo menos a atualização } \\
\text { da tecnologia); possuir um sistema de medida bem definido para } \\
\text { que o desempenho do serviço prestado possa ser avaliado } \\
\text { constantemente (antes e depois do início do contrato); possuir um } \\
\text { procedimento de operação e de recuperação de falhas com tarefas } \\
\text { de comunicação constante com o cliente; incluir cláusulas de } \\
\text { penalidade para ambas as partes no descumprimento do contrato; } \\
\text { determinar tachas de crescimento e se ajustar a mudanças no } \\
\text { negócio. Além disso, a questão do contrato deve ser avaliada pela } \\
\text { empresa cliente sempre com o acompanhamento de profissionais } \\
\text { com experiência nesse processo. }\end{array}$ \\
\hline $\begin{array}{l}\text { Contempla estudo de casos semelhantes realizados por outras } \\
\text { empresas ou descritos na literatura, para verificação dos riscos } \\
\text { incorridos em cada aspecto do processo decisório. Além disso, } \\
\text { pode proporcionar uma visão diferenciada sobre o processo como } \\
\text { um todo de forma a facilitar a decisão. }\end{array}$ \\
\hline
\end{tabular}

\begin{tabular}{|l|l|l|}
\hline Perguntas & Sim & Não \\
\hline $\begin{array}{l}\text { Você considera o aspecto "questões estratégicas" ao tomar } \\
\text { decisões de terceirização de funções de TI? }\end{array}$ & & \\
\hline $\begin{array}{l}\text { Você considera o aspecto "custos", da maneira descrita na } \\
\text { tabela acima, ao tomar decisões de terceirização de funções } \\
\text { de TI? }\end{array}$ & & \\
\hline $\begin{array}{l}\text { Você considera o aspecto "perfil do profissional de TI" ao } \\
\text { tomar decisões de terceirização de funções de TI? }\end{array}$ & & \\
\hline $\begin{array}{l}\text { Você considera o aspecto "riscos" ao tomar decisões de } \\
\text { terceirização de funções de TI? }\end{array}$ & & \\
\hline $\begin{array}{l}\text { Você considera o aspecto "contratos" ao tomar decisões de } \\
\text { terceirização de funções de TI? }\end{array}$ & & \\
\hline $\begin{array}{l}\text { Você considera o aspecto "bechmarking" ao tomar decisões } \\
\text { de terceirização de funções de TI? }\end{array}$ & & \\
\hline
\end{tabular}


No contexto de operação da empresa em que você trabalha, ao decidir sobre a terceirização de funções de $\mathrm{Tl}$, a consideração de cada um dos aspectos citados abaixo é?

\begin{tabular}{|l|l|l|l|l|l|}
\hline & Sem importância & $\begin{array}{l}\text { Pouco } \\
\text { importante }\end{array}$ & Importante & $\begin{array}{l}\text { Muito } \\
\text { importante }\end{array}$ & Fundamental \\
\hline Questões estratégicas & & & & & \\
\hline Custos & & & & & \\
\hline Perfil do profissional de TI & & & & & \\
\hline Riscos & & & & & \\
\hline Contratos & & & & & \\
\hline Benchmarking & & & & & \\
\hline
\end{tabular}

Na sua opinião, ao decidir sobre a terceirização de funções de TI, a consideração de cada um dos aspectos citados abaixo é?

\begin{tabular}{|l|l|l|l|l|l|}
\hline & Sem importância & $\begin{array}{l}\text { Pouco } \\
\text { importante }\end{array}$ & Importante & $\begin{array}{l}\text { Muito } \\
\text { importante }\end{array}$ & Fundamental \\
\hline Questões estratégicas & & & & & \\
\hline Custos & & & & & \\
\hline Perfil do profissional de TI & & & & & \\
\hline Riscos & & & & & \\
\hline Contratos & & & & & \\
\hline Benchmarking & & & & & \\
\hline
\end{tabular}




\section{ANEXO C - FORMULÁRIO USADO PARA RESPONDER À QUESTÃO DE PESQUISA Q4}

I - Identificação do respondente do questionário:

Nome:

Telefone para contato:

E-mail:

Cargo atual:

II - Informações sobre a empresa:

Nome:

Faturamento aproximado anual (opcional):

Número total de funcionários:

Possui capital aberto (ações em bolsa)? Sim ( ) Não ( )

III - Perguntas sobre decisão de terceirização:

Considere o entendimento sobre os aspectos descritos na tabela abaixo para responder as perguntas logo a seguir:

\begin{tabular}{|l|l|}
\hline Aspecto & Detalhamento \\
estratées & $\begin{array}{l}\text { Este aspecto volta-se, em grande parte, para os benefícios } \\
\text { incorridos com a formação de alianças estratégicas entre o cliente e } \\
\text { o fornecedor da terceirização. Alguns exemplos destes benefícios } \\
\text { são: utilização de inovaçôes e capacidades profissionais dos } \\
\text { fornecedores; possibilidade de rápidas mudanças de mercado e de } \\
\text { cenários tecnológicos, diminuindo riscos, ciclo de vida de produtos e } \\
\text { investimentos, além de criar um mecanismo de atendimento } \\
\text { imediato às necessidades dos clientes. }\end{array}$ \\
\hline Custos & $\begin{array}{l}\text { Esta questão aborda não somente os detalhes relacionados aos } \\
\text { custos das opções de terceirizar ou fazer internamente. Ele deve } \\
\text { cobrir aspectos relacionais aos chamados custos "escondidos", ou } \\
\text { seja, os custos incorridos com a administração do contrato (em caso } \\
\text { de terceirização) de eventuais mudanças de fornecedores, de } \\
\text { possíveis re-internalizações das funçôes terceirizadas, caso haja } \\
\text { descontentamento com o serviço prestado pelo fornecedor, etc. } \\
\text { Além disso, o conhecimento e aplicação dos conceitos de custos } \\
\text { transacionais são de grande relevância. }\end{array}$ \\
\hline
\end{tabular}




\begin{tabular}{|c|c|}
\hline $\begin{array}{l}\text { Perfil do } \\
\text { profissional } \\
\text { de TI }\end{array}$ & $\begin{array}{l}\text { Optar pela terceirização implica, necessariamente, em mudanças no } \\
\text { estilo de gestão da função da TI recém terceirizada. Antes da } \\
\text { terceirização, as pessoas envolvidas na operação da área } \\
\text { precisavam ter habilidades técnicas de forma a garantir a operação } \\
\text { do serviço. Após a terceirização, as habilidades das pessoas } \\
\text { envolvidas mudam de técnica para administrativa. Em outras } \\
\text { palavras, a área de TI do cliente deixa de ser operadora do serviço } \\
\text { para ser administradora. Além disso, a questão da terceirização } \\
\text { pode trazer impactos do ponto de vista estratégico e de novos } \\
\text { negócios. }\end{array}$ \\
\hline Riscos & $\begin{array}{l}\text { A questão dos riscos da terceirização das funções da TI é } \\
\text { amplamente discutida na literatura, além de possuir um } \\
\text { relacionamento direto com os outros aspectos discutidos nesta } \\
\text { tabela. Por exemplo, os custos escondidos de um processo de } \\
\text { terceirização possuem um relacionamento direto com os riscos de } \\
\text { insucesso, ou seja, um nível maior de custos não detectados pode } \\
\text { caracterizar um retorno financeiro menor que o esperado. Da } \\
\text { mesma forma, a perda de privacidade e de segurança das } \\
\text { informações, além da perda de experiência técnica da TI, parece } \\
\text { estar bastante relacionada ao aspecto de questões estratégicas. } \\
\text { Além disso, os riscos podem estar ligados ao próprio processo } \\
\text { decisório e ao escopo da terceirização. }\end{array}$ \\
\hline Contratos & $\begin{array}{l}\text { A questão da elaboração dos contratos de terceirização deve } \\
\text { discutir os pontos que viabilizem um contrato duradouro entre as } \\
\text { partes. Em outras palavras o contrato deve: garantir o } \\
\text { estabelecimento de uma aliança estratégica entre as partes; permitir } \\
\text { que os clientes tenham acessos ao conhecimento técnico do } \\
\text { fornecedor; trazer redução de custos para o cliente sempre que } \\
\text { houver mudança de base tecnológica (ou pelo menos a atualização } \\
\text { da tecnologia); possuir um sistema de medida bem definido para } \\
\text { que o desempenho do serviço prestado possa ser avaliado } \\
\text { constantemente (antes e depois do início do contrato); possuir um } \\
\text { procedimento de operação e de recuperação de falhas com tarefas } \\
\text { de comunicação constante com o cliente; incluir cláusulas de } \\
\text { penalidade para ambas as partes no descumprimento do contrato; } \\
\text { determinar tachas de crescimento e se ajustar a mudanças no } \\
\text { negócio. Além disso, a questão do contrato deve ser avaliada pela } \\
\text { empresa cliente sempre com o acompanhamento de profissionais } \\
\text { com experiência nesse processo. }\end{array}$ \\
\hline Benchmarking & $\begin{array}{l}\text { Contempla estudo de casos semelhantes realizados por outras } \\
\text { empresas ou descritos na literatura, para verificação dos riscos } \\
\text { incorridos em cada aspecto do processo decisório. Além disso, } \\
\text { pode proporcionar uma visão diferenciada sobre o processo como } \\
\text { um todo de forma a facilitar a decisão. }\end{array}$ \\
\hline
\end{tabular}




\begin{tabular}{|l|l|}
\hline $\begin{array}{l}\text { Na empresa em que você trabalha com que } \\
\text { freqüência os aspectos de avaliação da } \\
\text { decisão de terceirização de funções de TI } \\
\text { são considerados? }\end{array}$ & $\begin{array}{l}\text { Pontue numa escala de 0 a 10, } \\
\text { sendo: } \\
0 \text { - nunca é considerado e; } \\
10 \text { - sempre é considerado }\end{array}$ \\
\hline Questões estratégicas & \\
\hline Custos & \\
\hline Novas formas de gestão & \\
\hline Riscos & \\
\hline Contratos & \\
\hline Benchmarking & \\
\hline
\end{tabular}

\begin{tabular}{|c|c|}
\hline $\begin{array}{l}\text { Em sua opinião com que freqüência os } \\
\text { aspectos de avaliação da decisão de } \\
\text { terceirização de funções de TI deveriam ser } \\
\text { considerados? }\end{array}$ & $\begin{array}{l}\text { Pontue numa escala de } 0 \text { a } 10, \\
\text { sendo: } \\
0 \text { - não deveria ser considerado e; } \\
10 \text { - deveria sempre ser considerado }\end{array}$ \\
\hline \multicolumn{2}{|l|}{ Questões estratégicas } \\
\hline \multicolumn{2}{|l|}{ Custos } \\
\hline \multicolumn{2}{|l|}{ Novas formas de gestão } \\
\hline Riscos & \\
\hline Contratos & \\
\hline
\end{tabular}

IV - Sobre a Financeirização:

Responda a estas perguntas apenas se sua empresa possuir capital aberto. Marque apenas uma opção:

\begin{tabular}{|l|l|}
\hline $\begin{array}{l}\text { Na empresa em que você trabalha existe um } \\
\text { canal de contato com os acionistas? }\end{array}$ & $\operatorname{Sim}($ ) - Não ( ) \\
\hline $\begin{array}{l}\text { Você possui acesso ou conhece os desejos } \\
\text { dos acionistas? }\end{array}$ & $\operatorname{Sim}($ ) - Não ( ) \\
\hline $\begin{array}{l}\text { As decisões tomadas pela empresa são } \\
\text { influenciadas pelos desejos dos seus } \\
\text { acionistas? }\end{array}$ & $\operatorname{Sim}($ ) - Não ( ) \\
\hline $\begin{array}{l}\text { Na média, o valor das ações da empresa em } \\
\text { que você trabalha têm se mantido em que } \\
\text { estado nos últimos 12 meses? }\end{array}$ & $\begin{array}{l}\text { Em alta ( ) - Em queda ( ) - Estável } \\
(\text { ) }\end{array}$ \\
\hline $\begin{array}{l}\text { Nos últimos 12 meses, a empresa em que } \\
\text { você trabalha passou por alguma } \\
\text { reestruturação (ex: compra ou venda)? }\end{array}$ & $\operatorname{Sim}($ ) - Não ( ) \\
\hline
\end{tabular}


V - Sobre o Nível Hierárquico:

Responda às perguntas abaixo marcando apenas uma opção:

\begin{tabular}{|c|c|}
\hline $\begin{array}{l}\text { Quantos níveis hierárquicos a empresa em } \\
\text { que você trabalha possui? }\end{array}$ & $\begin{array}{l}2())-3()-4()-5()-\text { ou mais } \\
(())\end{array}$ \\
\hline $\begin{array}{l}\text { Você se considera em qual nível hierárquico } \\
\text { na empresa em que trabalha? }\end{array}$ & Alto ( )-Médio ( ) - Baixo ( ) \\
\hline $\begin{array}{l}\text { As decisões tomadas por você no seu dia-a- } \\
\text { dia são estratégicas a ponto de mudar o } \\
\text { direcionamento da sua empresa? }\end{array}$ & $\operatorname{Sim}($ ) - Não( ) \\
\hline $\begin{array}{l}\text { Você toma decisões operacionais em seu } \\
\text { dia-a-dia? }\end{array}$ & Sim ( ) - Nãol \\
\hline $\begin{array}{l}\text { Se você toma decisões estratégicas e } \\
\text { operacionais, qual delas demanda mais } \\
\text { tempo de você? }\end{array}$ & $\begin{array}{l}\text { Estratégicas ( ) - Operacionais ( ) - } \\
\text { Tomam o mesmo tempo ( ) }\end{array}$ \\
\hline
\end{tabular}

VI - Sobre o papel da TI na sua empresa:

Responda às perguntas abaixo marcando apenas uma opção:

\begin{tabular}{|l|l|}
\hline $\begin{array}{l}\text { A empresa pode reverter seus processos } \\
\text { para execução manual em 80\% das suas } \\
\text { transações? }\end{array}$ & $\operatorname{Sim}($ ) - Não ( ) \\
\hline $\begin{array}{l}\text { Se o sistema falhar por um minuto ou mais, } \\
\text { há uma perda imediata para o negócio? }\end{array}$ & $\operatorname{Sim}($ ) - Não ( ) \\
\hline $\begin{array}{l}\text { As despesas com TI somam mais do que } \\
15 \% \text { das despesas totais da empresa? }\end{array}$ & $\operatorname{Sim}($ ) - Não ( ) \\
\hline $\begin{array}{l}\text { Novos sistemas prometem significativas } \\
\text { transformações nos processos e serviços? }\end{array}$ & $\operatorname{Sim}($ ) - Não ( ) \\
\hline $\begin{array}{l}\text { Novos sistemas diminuirão } \\
\text { significativamente a distância do } \\
\text { desempenho de custo, serviço e processo } \\
\text { entre a empresa e seus competidores? }\end{array}$ & $\operatorname{Sim}($ ) - Não ( ) \\
\hline
\end{tabular}

VII - Sobre o alinhamento entre o negócio e a TI:

\begin{tabular}{|l|l|}
\hline Responda Pontuando numa escala de 0 a 10, sendo: & $\begin{array}{l}0 \text { - nunca ocorre e } \\
10 \text { - sempre ocorre. }\end{array}$ \\
\hline A TI é envolvida no desenvolvimento da estratégia? & \\
\hline A TI procura entender o negócio? & \\
\hline Parceria entre a TI e o negócio? & \\
\hline Projetos de TI são bem priorizados? & \\
\hline TI demonstra de liderança na organização? & \\
\hline
\end{tabular}

